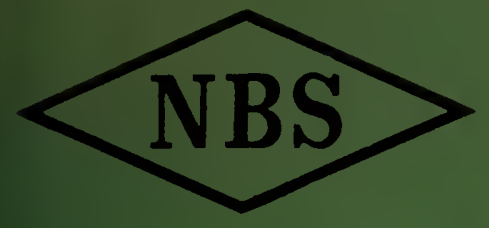

$\begin{array}{lll}\text { MAR } & 6 & 1973\end{array}$

.1 .96

Eechnical Mote

\title{
IMPEDANCE OF COMMERCIAL LECLANCHÉ DRY CELLS AND BATTERIES
}

RALPH J. BRODD AND HAROLD J. DEWANE

U. S. DEPARTMENT OF COMMERCE NATIONAL BUREAU OF STANDARDS 


\section{THE NATIONAL BUREAU OF STANDARDS}

\section{Functions and Activities}

The functions of the National Bureau of Standards are set forth in the $\Lambda$ ct of ('onirress. March 3, 1901, as amended by Congress in Public Law 619, 1950. These include the development and maintenance of the national standards of measurement and the provision of means and methorls for making measurements eonsistent with these standards; the determination of physical constants and properties of materinls; the development of methods and instruments for testing materials, devices, and structures; advisory serviees to government agencies on scicntifie and technical problems; invention and development of deviees to serve specinl needs of the Goverument; and the development of standard practices, codes, and specificntions. The work includes basic and applied researeh, development, engineering, instrumentation, testing, evaluation, calibration services, and various consultation and information services. Rescarch projects are also performed for other government acrencies when the work relates to and supplements the basic program of the Bureau or when the Bureau's unique competenee is required. The scope of activities is suggested by the listing of divisions and seetions on the inside of the baek cover.

\section{Publications}

The results of the Bureau's researeh are published either in the Bureau's own scries of publications or in the journals of professional and scientific societies. The Bureau publishes three periodicals available from the Government Printing Office: The Journal of Research, published in four separate sections, presents complete scientifie and technical papers; tle Technical News Bulletin presents summary and preliminary reports on work in progress; and thr Central Radio Propagation Laboratory Ionospheric Predictions provides data for determiningr the best frequencies to use for radio eommunications throughout the world. There are also five series of nonperiodical publications: Monograplis, Applied Mathematics Series, Handbooks, Miscellaneous Publications, and Teelınieal Notes.

A complete listing of the Bureau's publications ean be found in National Bureau of Standards Circular 460, Publications of the National Bureau of Standards, 1901 to June 1947 (\$1.25), and the Supplement to National Bureau of Standards Circular 460, July 1947 to June 1957 (\$1.50), and Miscellaneous Publication 240, July 1957 to June 1960 (includes Titles of Papers Published in Outside Journals 1950 to 1959) (\$2.25); available from the Superintendent of Documents, Government Printing Office, Wrshington 25, D.C. 


\title{
NATIONAL BUREAU OF STANDARDS
}

\author{
Eechnical Note 190
}

ISSUED JULY 5, 1963

\section{IMPEDANCE OF COMMERCIAL LECLANCHÉ DRY CELLS AND BATTERIES}

Ralph J. Brodd and Harold J. DeWane

NBS Technical Notes are designed to supplement the Bureau's regular publications program. They provide a means for making available scientific data that are of transient or limited interest. Technical Notes may be listed or referred to in the open literature. 
Contents

Page

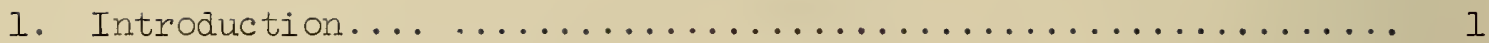

2. Impedance Measurements............................. 2

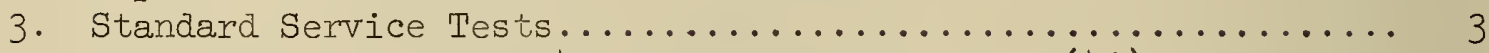

3.1. General-Purpose 4-ohm Intermittent Test $(4 \Omega) \ldots \ldots \ldots 3$

3.2. General-Purpose 2.25-ohm Intermittent Test (2.25 $\Omega$ ).... 3

3.3. Light-Industrial Flashlight-Cell Test (LIF).......... 3

3.4. Heavy-Industrial Flashlight-Cell Test (HIF).......... 4

3.5. Test and Storage Conditions..................... 4

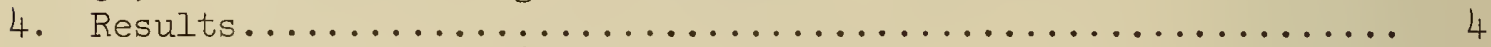

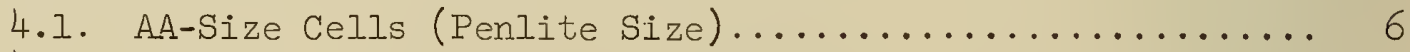

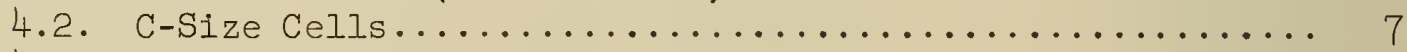

4.3 D-Size General-Purpose Cells.................. 7

4.4. D-Size Industrial Cells...................... 7

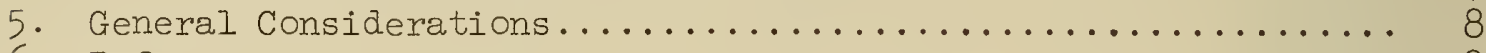

6. References.................................... 8 


\section{IMPEDANCE OF COMMERCIAI IECLANCHE' DRY CELIS AND BATTERIES}

Ralph J. Brodd and Harold J. DeWane

An extensive study of the impedance characteristics of the most commonly used sizes of commerclal Leclanche type dry cells and batteries has been made through the frequency range of 50 to 50,000 cycles. Changes in impedance due to aging and use were determinea. Open-circuit voltages and flash currents were measured, and capacities determined on standard tests in an effort to find a possible correlation between any of those three parameters and residual capacity. Data obtained are displayed in tabular form and on Argand diagrams.

\section{Introduction}

This note presents results of studies of the impedance of Ieclanche dry cells and batteries of various make, size, type, and condition. By condition is meant the age or the amount of electrical capacity remaining in the cells or batteries either after storage or after electrical discharge. Three sizes of cylindrical cells, AA, C, and D and various sizes of flat-cell 45-volt " $B$ " batteries were used in the studies. Dimensions of the cells and batteries are given in the tables referred to later. Impedance measurements were made on the cells prior to and after their discharge on various standard tests $[1]^{1}$; in fact, the measurements were made in conjunction with the qualification tests of dry cells and batteries which are conducted annually at the National Bureau of Standards. Impedance measurements were also made on cells and batteries prior to and after a specified period of storage at $21^{\circ} \mathrm{C}^{*}$.

1 Figures in brackets indicate literature references at the end of this paper.

*

Initial tests were made after cells and batteries were stored at $21^{\circ} \mathrm{C}$ for approximately one week. 


\section{Impedance Measurements}

The impedance was calculated from neasurements of the internal resistance and the capacitive reactance of the cells and batteries. These latter quantities were measured by a substitution method using a Wien bridge, as described by Grover [2] and Vinal [3], and shown schematically in figure $1 . R_{1}$ was a variable non-inductive resistor, graduated in 0.01 -ohm steps, covering a range up to $11,111.1$ ohms in six decades. Capacitor $\mathrm{C}_{1}$ consisted of two capacitors in parallel, continuously variable from $50 \mathrm{pf}$ to $1.111 \mu \mathrm{f}$ and served to compensate for the capacitance of the cell or battery under study. $R_{2}$ and $C_{2}$ were a fixed precision resistor and capacitor, respectively, and were selected to cover a range of $R$ and $C$ found for the cells or batteries under study. For single cells $R_{2}$ and $C_{2}$ were, respectively, 100 ohms and $l \mu f . R_{3}$ and $\mathrm{R}_{4}$ were 1000-precision ac resistors. Detector $\mathrm{D}$ was a tunable amplifier having a sensitivity of $5 \mu \mathrm{v}$ for a 10 per cent deflection of full scale. The oscillator was a wide-range type activated by 60-cycle ac and was coupled to the bridge by an isolation transformer, and had a range of $5 \mathrm{cps}$ to $600 \mathrm{kc}$. Its frequency was monitored by an electronic counter. The bridge was initially balanced with a thick, short copper bar, then with the cell or battery under study. This procedure was repeated at ten frequencies, namely, 50, 100, 200, and $500 \mathrm{cps}$ and 1, 2, 5, 10, 20, and $50 \mathrm{icc}$. All measurements were made at ambient room temperature which was about $26^{\circ} \mathrm{C}$.

The resistances and capacitances were calibrated by the Resistance and Reactance Section. To calibrate the Wien bridge a calibrated capacitor and a calibrated resistor were placed in the unknown positions and their values determined on balancing of the bridge. Results for a 1.0-ohm resistor and a $10 \mu f$ capacitor follow for severa.l frequencies:

Frequency

Resistance Capacitance

\begin{tabular}{lll}
$\begin{array}{l}\text { Standard } \\
\text { (DC }\end{array}$ Mealibration) & Standard & Measured \\
\hline
\end{tabular}

cycles/second

oims

onms

$\mu f$

$\mu f$

$\begin{array}{rllll}60 & 0.99943 & 0.998 & 10.5577 & 10.5497 \\ 100 & 0.99943 & 1.002 & 10.5501 & 10.5409 \\ 400 & 0.99943 & 0.999 & 10.5258 & 10.5166 \\ 1000 & 0.99943 & 0.999 & 10.5088 & 10.5011 \\ 20000 & 0.99943 & 1.000 & 10.74 & 10.7778\end{array}$


Measured values generally agreed with calibrated values within 0.1 per cent; therefore, residuals in the bridge arms were insignificant for the purpose.

The resistance, $R$, and the capacitive reactance, $x_{c}$, were obtained at each frequency from

$$
\begin{gathered}
R=R_{i}-R_{f} \\
X_{c}=\frac{1}{\omega}\left[\frac{1}{\bar{C}_{i}}-\frac{1}{C_{f}}\right]
\end{gathered}
$$

where $C=$ capacitance, $\omega=2 \pi f$ where $f$ is the frequency in cycles per second (cps), and $\underline{i}$ and $\underline{f}$ refer to the initial (with bar) and final (with cell) balances. From these, the impedance, $z$, is obtained from

$$
z=\sqrt{R^{2}+x_{c}^{2}}
$$

\section{Standard Service Tests}

The resistance, capacitive reactance, and impedance were not only determined for new and aged cells but for cells after they had been discharged on one of the following standara tests [1]:

\subsection{General-Purpose 4-ohm Intermittent Test $(4 \Omega)$.}

Each cell is discharged through a resistance of 4 ohms for 5-minute periods at 24-hour intervals. The test is continued until the closedcircuit voltage of the cell falls below 0.75 volt. The service is reported as the number of minutes of discharge before the cell voltage falls below 0.75 volt.

\subsection{General-Purpose 2.25-ohm Intermittent Test (2.25 2 ).}

Each cell is discharged through a resistance of 2.25 ohms for 5minute periods at 24-hour intervals. The test is continued until the closed-circuit voltage of the cell falls below 0.65 volt. The service is reported as the number of minutes of discharge before the cell voltage falls below 0.65 volt.

\subsection{Light-Industrial Flashlight-Cell Test (LIF).}

Each cell is discharged through a resistance of 4 ohms for 4minute periods, beginning at hourly intervals for 8 consecutive hours each day, with 16-hour rest periods intervening. The test in continued 
until the closed-circuit voltage of the cell falls below 0.90 volt. The service is reported as the number of minutes of discharge before the cell voltage first falls below 1.10 volts and then below 0.90 volt.

\subsection{Heavy-Industrial Flashlight-Cell Test (HIF).}

Each cell is discharged through a resistance of 4 ohms for 4-minute periods, beginning at 15-minute intervals, for 8 consecutive hours each day, with 16-hour rest periods intervening. The test is continued until the closed-circuit voltage of the cell falls below 0.90 volt. The service is reported as the number of minutes of discharge before the cell voltage first falls below 1.10 volts and then below 0.90 volt.

Prior to and at times during the tests the open-circuit voltage of the cells or batteries was measured with a voltmeter having a resistance of 1,000 ohms per volt. Also, the short-circuit current of the cells was measured with a critically-damped ammeter having a resistance, with the leads, of $0.01 \mathrm{ohm}$. The impedance of the cells or batteries was measured on the day following or on the day preceding the standard discharge test.

\subsection{Test and Storage Conditions}

"Initial" tests intended to show the condition of fresh batteries shall be started within 30 days of the receipt of the batteries by the testing agency.

"Delayed" tests are intended to measure the keeping quality of cells and batteries. Cells and batteries for delayed test shall be stored on open-circuit at a temperature of $70 \pm 2^{\circ} \mathrm{F}\left(21^{\circ} \mathrm{C}\right.$ ) for the time specified. The storage time specified shall be measured from the time at which the batteries were received by the testing agency.

The standard temperature for tests is $70 \pm 2^{\circ} \mathrm{F}\left(21^{\circ} \mathrm{C}\right)$ unless otherwise specified.

\section{Results}

Results obtained on fresh (or new) and discharged (on standard tests) AA-size general-purpose, C-size general-purpose, D-size generalpurpose, and D-size industrial Leclanche dry cells, and on 45-volt Leclanche ary batteries of various make are given in tables 1 to 5 , inclusive. In each case the results are the average of the number of cells listed in the table heading. In tables 1 to 4, inzlusive, the condition of the cell at the time of the impedance measurements is listed in the next to the last column. The number given in the last 
column of these tables refers to the diagrams discussed below. For fresh cells the values of the open-circuit voltage (OCV) and the shortcircuit current (SCC) are given. For the various discharge tests the number of minutes obtained on the discharge is listed; this is the service obtained from the cell before the final impedance measurements were made. When more than one discharge test was made on a particular brand of cell, the second or third test was made on a similar cell chosen from the same production lot. Inspection of the data shows clearly that there are no clear-cut correlations between output and internal resistance, impedance, open-circuit voltage, or short-circuit current. In table 6 a summary is given where the data, for any one cell size or type, are listed in order of increasing values for the internal resistance. One would expect that the output would decrease, within any one group, as one goes down the table; instead, no such tread is evident.

The data of table 5 refer to 45-volt batteries of 30 cells in series. Since it was not possible to complete the measurements of the batteries, whether simultaneously or within a short period of time, the batteries had an age ranging from 1 to 4 months at the time of the impedance measurement. Batteries F100 (brand 6) and F100 (brand 7) were discharged on the 2500-radio " $B$ " battery test as described in reference [1]. In this test each 22.5-volt battery unit is discharged through a resistance of 2,500 ohms for a continuous period of 4 hours daily, with the intervals between successive discharge periods being not less than 16 hours. The test is continued until the closed-circuit voltage falls below 15 volts per 22.5 volt unit. On this test, batteries F100 (brand 6) and F100 (brand 7), although their internal impedances differed by a considerable amount ( 82.7 per cent at $1000 \mathrm{cps}$ ), gave nearly the same service, viz., 559 and 595 hours, respectively. Here again the lack of a correlation between cell output and internal impedance is evident.

The impedance is a function of the frequensy and decreases as the frequency is increased, approaching a constant value in the limit. At the higher frequencies the impedance tends to have the characteristics of a resistive element; this tendency begins at about 1,000 cps. At the lower frequencies the capacitance of the electrode-electrolyte interface comes into play.

In table 7 the effect of aging on the impedance is summarized. The data given are in percentage changes which occur during a 6-month or a 3 -month aging period at $21^{\circ} \mathrm{C}$. Aging does not change the impedance much at the higher frequencies, above 1,000 cps where the impedance has the characteristics of a resistive element. Above and including the frequency of $1,000 \mathrm{cps}$, the average increase in impedance is only 3.0 per cent for $\mathrm{C}$-size cells, 2.4 per cent of D-size general-purpose cells, and 4.8 per cent for D-size industrial cells. Below 1,000 cps, 
aging increases the impedance considerably and a progressively higher amount as the frequency is decreased. The increase in the impedance at the lower frequencies is a manifestation of an increase in the resistance at the electrode-electrolyte interface.

In table 8 the effects of various types of discharges on the impedance are summarized, likewise in percentage changes. As is the case for aging, different phenomena are seen to occur above and below a frequency of about 1,000 cps. At the higher frequencies the percentage change in impedance is nearly constant with frequency and is quite large. This change In impedance is not related to the output given by the cells, as was shown above in table 6 for frequencles of 1,000 cps. At the lower frequencies the percentage changes, in general, were of lower magnitude showing that the resistive element at the electrode-electrolyte interface is decreased during or as a result of electrical discharge. This decrease was so large in some cases that the percentage changes were negative. Increase in electrode capacitance during discharge would also contribute to a lowering of the electrode impedance.

In figures 2 to 52, inclusive, Argand diagrams are given for the various cells having the conlition listed in the next to the last column of tables 1 to 4, inclusive. In these diagrams the capacitive reactance, $\mathrm{X}_{C}$, is plotted against the resistance, $R$, where each point corresponds to one definite frequency in cycles per second and is so labeled. The vector from the origin to where the curve (at the left) cuts the $R$ axis gives the resistive component of the impedance which is frequency independent whereas the vector from the orlgin to a point on the curve gives the total impedance. The angle the vector makes with the real' axis is the phase angle for that frequency.

\subsection{AA-Size Cells (Penlite Size).}

Argand diagrams for new (fresh or undischarged) AA-size Leclanché cells of 4 different manufacturers are shown in figures $2,4,6$, and 8 , respectively; the corresponding diagrams after the cells were discharged on the general-purpose 4-ohm intermittent test are shown, respectively, in figures 3, 5, 7, and 9. In the first group of figures (No.6 excepted) the open-circuit voltage (OCV), short-circuit or flash current (SCC), and performance on test (PT) are given. The units for OCV, SCC, and PT are, respectively, volts, amperes, and minutes. These figures show that cells of the same size (AA) but of different manufacture exhibit widely different impedance characteristics not only when new and undischarged but also after discharge on the same test procedure. Furthermore, none of the cells exhibit a semi-circle with the abscissa, which is a necessary result if simple relaxation processes as a function of frequency prevail in the electrode processes [4]. 
Argand diagrams for new (fresh or undischarged) C-size Leclanché cells of 4 different manufacturers are shown in figures 10, 13, 16, and 19, respectively; the corresponding diagrams for the respective cells after they were stored for 6 months are given in figures 11, 14, 17, and 20 , respectively. In the first group of figures OCV, SCC, and PT mean the same as above. The figures also show the wide difference in the impedance of cells of the same size (c) but of different manufacture. Here, however, the difference is not as marked as for AA-size cells and the diagrams approximate a semi-circle much more closely. After the cells were discharged on the general-purpose 4-ohm intermittent test they exhibited, respectively, the impedance shown in figures 12, 15, 18, and 21.

\subsection{D-Size General-Purpose Cells.}

Argand diagrams for D-size general-purpose Leclanché cells of 5 different manufacture when new, after 6-month storage, after discharge on the light-industrial test, 2.25-ohm test, and the general-purpose 4-ohm test are shown in the corresponding figures as listed below:

\begin{tabular}{cccccc} 
Brand & New & 6-month & IIF & 2.25-ohm & 4-ohm \\
\cline { 3 - 5 } 1 & 22 & 23 & 24 & 25 & 26 \\
2 & 27 & 28 & 29 & 30 & - \\
3 & 31 & - & 32 & - & - \\
4 & 33 & 34 & - & 35 & - \\
5 & 36 & 37 & 38 & 39 & 40 \\
6 & 41 & 42 & 43 & 44 & 45
\end{tabular}

Here again, we see the wide difference in the impedance of cells of the same size bit of different manufacture. In some cases the Argand diagrams approach a semi-circle in shape; in other cases a semi-circle would become complete only at very low frequencies, if at all.

\subsection{D-Size Industrial Cells.}

Argand diagrams for D-size industrial Leclanché cells of 2 different manufacture when new, after 3-month storage, after discharge on the lightindustrial test, and after the heavy-industrial test are shown in the corresponding figures as listed below:

$\begin{array}{ccccc}\text { Brand } & \text { New } & \text { 3-month } & \text { IIF } & \text { HIF } \\ 1 & 46 & 47 & 48 & - \\ 2 & 49 & 50 & 51 & 52\end{array}$


As with D-size general-purpose cells the diagrams are different for cells of different make. Again, semi-circles are approximated.

\section{General Considerations}

In the above it has been shown that the impedance of Leclanche dry cells of different make, size, type, and condition varies widely, not only at a particular frequency, but as a function of frequency. In some cases the impedance tends toward a maximum at a particular frequency and then decreases as the frequency is lowered. In other cases, the impedance tends to increase, as the frequency is lowered. The over-all characteristics of the Leclanche cell depend on the type of cell construction and since this is not known and frequently cannot be ascertained no correlation of impedance with cell construction is possible, here. Even so, relative changes that occur in the impedance of Leclanche cells on storage or on electrical discharge may be followed by the method described here.

The authors wish to thank $\mathrm{Dr}$. W. J. Hamer for his patient guidance and his help in preparing the manuscript. It is also appropriate to acknowledge the discussions with many mamebers of the staff of the National Bureau of Standards during the course of this investigation, especially Drs. F. R. Kotter, J. Lauritzen, J. D. Hoffman and C. H. Page. Also the authors thank $\mathrm{W}$. J. Vadnais for his help in conducting the standard tests.

\section{References}

[1] "Specification for Dry Cells and Batteries", Natl, Bur. Standards Handbook 71, December 29, 1959; American Standards Association Standard C18.1-1959; UDC 621.352.7.

[2] F. W. Grover, Bull. Natl. Bur. Standards 3, 378(1907).

[3] G.W. Vinal, "Storage Batteries", 4th Ed., p. 328, John Wiley and Sons, New York, N. Y., 1955. 
Table 1. Impedance Data on AA-size General-purpose Leclanché Dry Cells; Average of 3 Cells in Each Case.

[AA Cells: diameter, 17/32 inch; can height, $17 / 8$ inches]

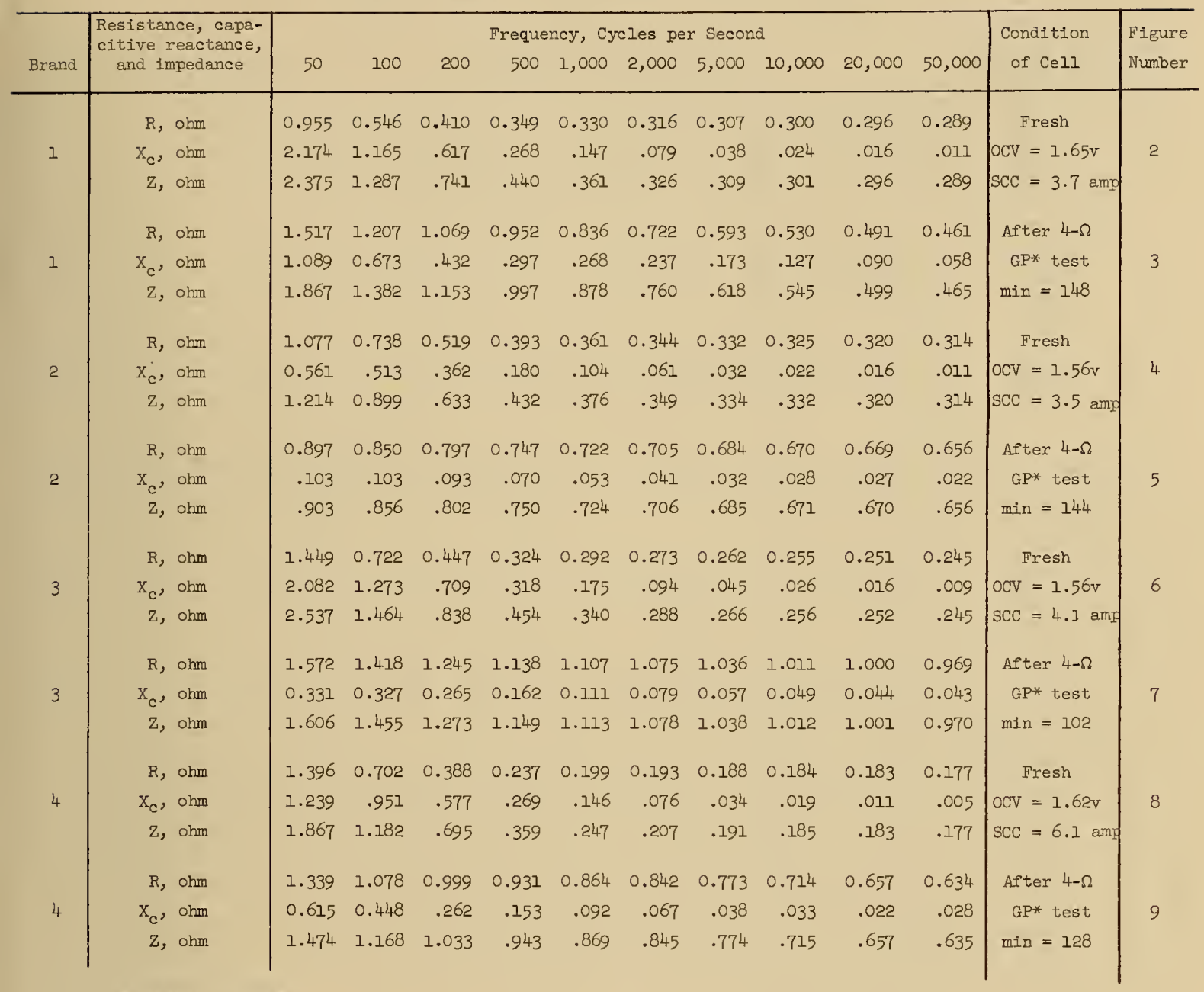

* $-G P=$ general purpose 
Table 2. Impedance Data on C-size General-purpose Leclanché Dry Cells; Average of 3 Cells in Each Case.

[C Cells: diameter, 15/16 inch; can height 1 13/16 inches]

\begin{tabular}{|c|c|c|c|c|c|c|c|c|c|c|c|c|c|}
\hline Brand & $\begin{array}{l}\text { Resistance, capa- } \\
\text { citive reactance, } \\
\text { and Impedance }\end{array}$ & 50 & 100 & 200 & $\begin{array}{l}\text { Freque } \\
500\end{array}$ & $\begin{array}{l}\text { ncy, Cy } \\
1,000\end{array}$ & $\begin{array}{l}\text { cles pe } \\
2,000\end{array}$ & $\begin{array}{l}\text { r Secon } \\
5,000\end{array}$ & 10,000 & 20,000 & 50,000 & $\begin{array}{l}\text { Condition } \\
\text { of Cell }\end{array}$ & $\begin{array}{l}\text { Figure } \\
\text { Number }\end{array}$ \\
\hline \multirow{3}{*}{1} & $\mathrm{R}$, ohm & 0.509 & 0.487 & 0.356 & 0.297 & 0.259 & 0.237 & 0.224 & 0.218 & 0.215 & 0.213 & Fresh & \\
\hline & $x_{c}$, ohm & .035 & .048 & .067 & .074 & .059 & .038 & .020 & .013 & .008 & .004 & $O \mathrm{CV}=1.60 \mathrm{v}$ & 10 \\
\hline & Z, ohm & .510 & .489 & .362 & .306 & .266 & .240 & .225 & .219 & .215 & .213 & $\mathrm{sCC}=5.4 \mathrm{amp}$ & \\
\hline \multirow{3}{*}{1} & R, ohm & 0.638 & 0.586 & 0.437 & 0.307 & 0.262 & 0.246 & 0.233 & 0.229 & 0.226 & 0.225 & After 6- & \\
\hline & $x_{c}, o h m$ & .136 & .186 & .198 & .139 & .086 & .052 & .026 & .016 & .009 & .005 & month & 11 \\
\hline & $\mathrm{Z}$, ohm & .652 & .615 & .480 & $\cdot 337$ & .276 & .251 & .234 & .230 & .226 & .225 & aglng & \\
\hline \multirow{3}{*}{1} & $\mathrm{R}$, ohm & 1.396 & 1.296 & 1.148 & 1.006 & 0.931 & 0.871 & 0.803 & 0.785 & 0.774 & 0.742 & After $4-\Omega$ & \\
\hline & $\mathrm{x}_{\mathrm{c}}$, ohm & 0.212 & 0.242 & 0.243 & 0.204 & .156 & .117 & .076 & .068 & .058 & .050 & GP* test & 12 \\
\hline & $\mathrm{z}, \mathrm{ohm}$ & 1.412 & 1.319 & 1.174 & 1.026 & .944 & .879 & .807 & .788 & .776 & .744 & $\min =430$ & \\
\hline \multirow{3}{*}{2} & $R$, ohm & 0.521 & 0.501 & 0.476 & 0.414 & 0.374 & 0.343 & 0.320 & 0.306 & 0.301 & 0.291 & Fresh & \\
\hline & $x_{c}$, ohm & .031 & .046 & .068 & .082 & .070 & .054 & .037 & .027 & .019 & .011 & $\mathrm{OCV}=1.56 \mathrm{v}$ & 13 \\
\hline & $\mathrm{z}, \mathrm{ohm}$ & .522 & .503 & .481 & .422 & .381 & .347 & $\cdot 322$ & $\cdot 307$ & $\cdot 302$ & .291 & $\mathrm{SCC}=3.8 \mathrm{amp}$ & \\
\hline \multirow{3}{*}{2} & $R$, ohm & 0.869 & 0.682 & 0.513 & 0.404 & 0.365 & 0.344 & 0.323 & 0.309 & 0.303 & 0.293 & After 6- & \\
\hline & $\mathrm{x}_{\mathrm{c}}$, ohm & $\cdot 317$ & .365 & .246 & .145 & .094 & .063 & .040 & .029 & .021 & .013 & month & 14 \\
\hline & $\mathrm{Z}$, ohm & .925 & .774 & .569 & .429 & $\cdot 377$ & .350 & $\cdot 326$ & .310 & .304 & .293 & agIng & \\
\hline \multirow{3}{*}{2} & $R$, ohm & 1.172 & 1.108 & 1.056 & 1.052 & 0.980 & 0.933 & 0.898 & 0.880 & 0.865 & 0.852 & After $4-\Omega$ & \\
\hline & $\mathrm{X}_{\mathrm{c}}, \mathrm{ohm}$ & 0.102 & 0.116 & 0.113 & 0.093 & .079 & .062 & .047 & .041 & .038 & .035 & GP* test & 15 \\
\hline & Z, ohm & 1.177 & 1.114 & 1.062 & 1.056 & .983 & .935 & .899 & .881 & .866 & .852 & $\min =406$ & \\
\hline \multirow{3}{*}{3} & $R$, ohm & 0.876 & 0.778 & 0.617 & 0.387 & 0.305 & 0.260 & 0.236 & 0.228 & 0.225 & 0.223 & Fresh & \\
\hline & $\mathrm{X}_{\mathrm{c}}, \mathrm{ohm}$ & .159 & .238 & .286 & .240 & .164 & .095 & .048 & .026 & .014 & .006 & $\mathrm{OCV}=1.61 \mathrm{v}$ & 16 \\
\hline & Z, ohm & .890 & .814 & .680 & .455 & .346 & .277 & .241 & .229 & .225 & .223 & $\mathrm{SCC}=5.3 \mathrm{amp}$ & \\
\hline \multirow{3}{*}{3} & $\mathrm{R}$, ohm & 1.521 & 0.971 & 0.545 & 0.341 & 0.289 & 0.268 & 0.253 & 0.247 & 0.247 & 0.244 & After 6- & \\
\hline & $\mathrm{X}_{\mathrm{c}}$, ohm & 0.964 & .862 & .596 & .296 & .167 & .094 & .044 & .024 & .012 & .006 & month & 17 \\
\hline & Z, ohm & 1.801 & 1.298 & .808 & .452 & .334 & .284 & .257 & .248 & .247 & .244 & aging & \\
\hline \multirow{3}{*}{3} & $R$, ohm & 1.143 & 1.081 & 1.011 & 0.969 & 0.953 & 0.935 & 0.925 & 0.923 & 0.909 & 0.898 & After $4-\Omega$ & \\
\hline & $\mathrm{x}_{\mathrm{c}}$, ohm & 0.141 & 0.125 & 0.098 & .061 & .044 & .032 & .024 & .022 & .020 & .021 & GP* test & 18 \\
\hline & Z, ohm & 1.152 & 1.089 & 1.016 & 971 & .954 & .936 & .925 & .923 & .909 & .898 & $\min =420$ & \\
\hline \multirow{3}{*}{4} & $R$, ohm & 0.625 & 0.547 & 0.457 & 0.376 & 0.336 & 0.331 & 0.323 & 0.317 & 0.313 & 0.308 & Fresh & \\
\hline & $x_{c}$, ohm & .110 & .147 & .148 & .098 & .064 & .040 & .021 & .015 & .011 & .009 & OCV $=1.59 \mathrm{v}$ & 19 \\
\hline & $\mathrm{z}, \mathrm{ohm}$ & .635 & .566 & .480 & $\cdot 389$ & $\cdot 342$ & .333 & $\cdot 324$ & $\cdot 317$ & .313 & $\cdot 308$ & $\mathrm{SCC}=4.0 \mathrm{amp}$ & \\
\hline \multirow{3}{*}{4} & $R$, ohm & 0.754 & 0.625 & 0.480 & 0.382 & 0.350 & 0.335 & 0.323 & 0.318 & 0.316 & 0.310 & After 6- & \\
\hline & $x_{c}$, ohm & .213 & .219 & .201 & .121 & .075 & .045 & .025 & .017 & .012 & .008 & month & 20 \\
\hline & Z, ohm & .784 & .662 & .520 & .401 & .358 & .338 & $\cdot 324$ & .319 & $\cdot 316$ & .310 & agling & \\
\hline \multirow{3}{*}{4} & $\mathrm{R}$, ohm & 1.550 & 1.494 & 1.465 & 1.406 & 1.372 & 1.345 & 1.315 & 1.303 & 1.277 & 1.251 & After $4-\Omega$ & \\
\hline & $\mathrm{x}_{\mathrm{c}}$, ohm & .024 & .066 & .072 & .075 & .071 & .061 & .051 & .047 & .043 & .044 & GP* test & 21 \\
\hline & Z, ohm & 1.550 & 1.495 & 1.467 & 1.408 & 1.374 & 1.346 & 1.316 & 1.304 & 1.278 & 1.252 & $\min =462$ & \\
\hline
\end{tabular}

* - GP = general purpose 
Table 3. Impedance Data on D-size General-purpose Leclanche Dry Cells; Average of 9 Cells in Each Case

[D Cells: diameter, $11 / 4$ inches; can height, $21 / 4$ inches]

\begin{tabular}{|c|c|c|c|c|c|c|c|c|c|c|c|c|c|}
\hline Brand & $\begin{array}{l}\text { Resistance, capa- } \\
\text { citive reactance, } \\
\text { and impedance }\end{array}$ & 50 & 100 & 200 & $\begin{array}{l}\text { Frequer } \\
500\end{array}$ & $\begin{array}{l}\text { ney, Cyc } \\
1,000\end{array}$ & $\begin{array}{l}\text { cles per } \\
2,000\end{array}$ & $\begin{array}{l}r \text { Second } \\
5,000\end{array}$ & 10,000 & 20,000 & 50,000 & $\begin{array}{c}\text { Condition } \\
\text { of Cell }\end{array}$ & $\begin{array}{l}\text { Figure } \\
\text { Number }\end{array}$ \\
\hline \multirow{3}{*}{1} & $\mathrm{R}$, ohm & 0.246 & 0.238 & 0.232 & 0.211 & 0.189 & 0.174 & 0.160 & 0.153 & 0.151 & 0.151 & Fresh & \multirow{3}{*}{22} \\
\hline & $x_{c}, o h m$ & .007 & .015 & .023 & .034 & .035 & .028 & .015 & .011 & .007 & .004 & $\mathrm{OCV}=1.58 \mathrm{v}$ & \\
\hline & $\mathrm{z}$, ohm & .246 & .238 & .233 & .214 & .192 & .176 & .161 & .153 & .151 & .151 & $\mathrm{SCC}=7.1 \mathrm{amp}$ & \\
\hline \multirow{3}{*}{1} & $\mathrm{R}$, ohm & 0.262 & 0.251 & 0.239 & 0.206 & 0.191 & 0.165 & 0.163 & 0.159 & 0.159 & 0.154 & After 6- & \multirow{3}{*}{23} \\
\hline & $x_{c}$, ohm & .014 & .022 & .034 & .049 & .036 & .026 & .015 & .010 & .007 & .003 & month & \\
\hline & Z, ohm & .262 & .252 & .241 & .212 & .194 & .167 & .164 & .159 & .159 & .154 & aging & \\
\hline \multirow{3}{*}{1} & $R$, ohm & 0.719 & 0.690 & 0.658 & 0.602 & 0.565 & 0.526 & 0.482 & 0.461 & 0.452 & 0.448 & After & \multirow{3}{*}{24} \\
\hline & $x_{c}$, ohm & .065 & .066 & .072 & .084 & .087 & .077 & .059 & .046 & .033 & .022 & $\operatorname{LIF}^{\mathrm{a}}$ & \\
\hline & Z, ohm & .722 & .693 & .662 & .608 & .572 & .532 & .486 & .463 & .453 & .449 & & \\
\hline \multirow{3}{*}{1} & $\mathrm{R}$, ohm & 1.180 & 1.149 & 1.109 & 1.043 & 0.963 & 0.833 & 0.794 & 0.753 & 0.718 & 0.693 & After $2.25-\Omega$ & \multirow{3}{*}{25} \\
\hline & $x_{c}$, ohr & .034 & .085 & 0.106 & 0.138 & .154 & .147 & .116 & .088 & .065 & .047 & GP* test ${ }^{b}$ & \\
\hline & Z, ohm & 1.180 & 1.153 & 1.114 & 1.052 & .975 & .845 & .802 & .758 & .721 & .695 & $\min =444$ & \\
\hline \multirow{3}{*}{1} & R, ohrm & 1.253 & 1.224 & 1.192 & 1.115 & 1.032 & 0.938 & 0.826 & 0.772 & 0.742 & 0.713 & After $4-\Omega$ & \multirow{3}{*}{26} \\
\hline & $\mathrm{X}_{\mathrm{c}}$, ohm & .068 & .083 & 0.106 & 0.119 & 0.179 &. .79 & .139 & .102 & .116 & .046 & GP* test & \\
\hline & $\mathrm{z}$, ohm & 1.255 & 1.227 & 1.197 & 1.121 & 1.047 & .955 & .838 & .779 & .751 & .714 & $\min =584$ & \\
\hline \multirow{3}{*}{2} & $\mathrm{R}$, ohm & 0.330 & 0.303 & 0.263 & 0.214 & 0.196 & 0.183 & 0.171 & 0.164 & 0.159 & 0.155 & Fresh & \multirow{3}{*}{27} \\
\hline & $\mathrm{x}_{\mathrm{c}}$, ohm & .045 & .064 & .068 & .053 & .038 & .028 & .018 & .013 & .008 & .004 & $\mathrm{OCV}=1.56 \mathrm{v}$ & \\
\hline & Z, ohm & .333 & .336 & .272 & .220 & .199 & .185 & .172 & .165 & .159 & .155 & $\mathrm{SCC}=6.9 \mathrm{amp}$ & \\
\hline \multirow{3}{*}{2} & $\mathrm{R}$, ohm & 0.458 & 0.343 & 0.259 & 0.212 & 0.195 & 0.184 & 0.174 & 0.170 & 0.165 & 0.165 & After 6- & \multirow{3}{*}{28} \\
\hline & $x_{c}$, ohm & .277 & .166 & .124 & .070 & .046 & .031 & .020 & .014 & .010 & .005 & month & \\
\hline & Z, ohm & .491 & .381 & .287 & .223 & .200 & .187 & .175 & .171 & .165 & .165 & aging & \\
\hline \multirow{3}{*}{2} & $R$, ohre & 0.328 & 0.319 & 0.298 & 0.284 & 0.276 & 0.273 & 0.270 & 0.267 & 0.265 & 0.259 & After & \multirow{3}{*}{29} \\
\hline & $x_{c}, o h m$ & .029 & .033 & .029 & .019 & .014 & .007 & .007 & .005 & .004 & .002 & $\operatorname{LIF}^{\mathrm{a}}$ & \\
\hline & $\mathrm{Z}$, ohm & $\cdot 329$ & $\cdot 321$ & .299 & .285 & .276 & .273 & .271 & .267 & .265 & .259 & $\min =642$ & \\
\hline \multirow{3}{*}{2} & $R$, ohm & 0.756 & 0.708 & 0.675 & 0.650 & 0.635 & 0.633 & 0.625 & 0.622 & 0.617 & 0.613 & After $2.25-\Omega$ & \multirow{3}{*}{30} \\
\hline & $x_{c}$, onm & .087 & .072 & .058 & .040 & .032 & .026 & .020 & .015 & .013 & .010 & GP* test & \\
\hline & $\mathrm{z}$, ohm & .161 & .712 & .678 & .651 & .636 & .634 & .625 & .622 & .617 & .613 & $\min =533$ & \\
\hline \multirow{3}{*}{$3_{1}$} & $\mathrm{R}$, ohm & 0.335 & 0.314 & 0.241 & 0.238 & 0.224 & 0.207 & 0.184 & 0.181 & 0.180 & 0.175 & Fresh & \multirow{3}{*}{31.} \\
\hline & $\mathrm{X}_{\mathrm{c}}$, ohm & .006 & .005 & .011 & .021 & .028 & .030 & .022 & .015 & .010 & .008 & $\mathrm{OCV}=1.68 \mathrm{v}$ & \\
\hline & $\mathrm{z}, \mathrm{ohm}$ & .335 & .314 & .241 & .239 & .226 & .209 & .185 & .182 & .180 & .175 & $\mathrm{sCC}=7.3 \mathrm{amp}$ & \\
\hline \multirow{3}{*}{31} & $\mathrm{R}$, ohm & 0.639 & 0.608 & 0.5961 & 0.507 & 0.482 & 0.468 & 0.460 & 0.455 & 0.449 & 0.444 & After & \multirow{3}{*}{32} \\
\hline & $x_{c}$, ohm & .056 & .075 & .082 & .064 & .044 & .029 & .016 & .011 & .009 & .008 & $\mathrm{LIF}^{\mathrm{a}}$ & \\
\hline & Z, ohm & .641 & .613 & .567 & .511 & .484 & .469 & .460 & .455 & .449 & .444 & $\min =693$ & \\
\hline \multirow{3}{*}{32} & $\mathrm{R}$, ohm & 0.975 & 0.755 & 0.502 & 0.298 & 0.233 & 0.212 & 0.194 & 0.190 & 0.188 & 0.188 & Fresh & \multirow{3}{*}{33} \\
\hline & $x_{c}$, ohm & .310 & .409 & $\cdot 377$ & .230 & .135 & .077 & .036 & .020 & .011 & .005 & $\mathrm{OCV}=1.61 \mathrm{v}$ & \\
\hline & Z, ohm & 1.023 & .859 & .628 & $\cdot 376$ & .269 & .225 & .197 & .191 & .188 & .188 & $\mathrm{scc}=6.5 \mathrm{amp}$ & \\
\hline
\end{tabular}


Table 3. (CONTINUED)

\begin{tabular}{|c|c|c|c|c|c|c|c|c|c|c|c|c|c|}
\hline Brand & $\begin{array}{l}\text { Resistance, capa- } \\
\text { citive reactance, } \\
\text { and impedance }\end{array}$ & 50 & 100 & 200 & $\begin{array}{l}\text { Freque } \\
500\end{array}$ & $\begin{array}{l}\text { ney, Cy } \\
1,000\end{array}$ & $\begin{array}{l}\text { cles pe } \\
2,000\end{array}$ & 5,000 & 10,000 & 20,000 & 50,000 & $\begin{array}{c}\text { Condition } \\
\text { of Cell }\end{array}$ & $\begin{array}{l}\text { Figure } \\
\text { Number }\end{array}$ \\
\hline \multirow{3}{*}{32} & $\mathrm{R}$, ohm & 1.255 & 0.663 & 0.383 & 0.258 & 0.229 & 0.215 & 0.205 & 0.204 & 0.201 & 0.201 & After 6- & \multirow{3}{*}{34} \\
\hline & $x_{c}$, ohm & 1.275 & .910 & .522 & .239 & .131 & .073 & .035 & .018 & .011 & .005 & month & \\
\hline & Z, ohm & 1.789 & 1.126 & .647 & .352 & .264 & .227 & .208 & .205 & .201 & .201 & aging & \\
\hline \multirow{3}{*}{32} & $R$, ohm & 0.882 & 0.792 & 0.720 & 0.676 & 0.655 & 0.636 & 0.620 & 0.607 & 0.605 & 0.592 & After $2.25-\Omega$ & \multirow{3}{*}{35} \\
\hline & $x_{c}, o h m$ & .184 & .157 & .119 & .073 & .054 & .040 & .029 & .025 & .023 & .021 & GP* test & \\
\hline & Z, ohm & .901 & .807 & .729 & .680 & .657 & .637 & .621 & .607 & .605 & .592 & $\min =538$ & \\
\hline \multirow{3}{*}{4} & $\mathrm{R}$, ohm & 0.401 & 0.354 & 0.307 & 0.241 & 0.208 & 0.193 & 0.185 & 0.181 & 0.178 & 0.175 & Fresh & \multirow{3}{*}{36} \\
\hline & $x_{c}, o h m$ & .049 & .077 & .090 & .074 & .051 & .034 & .017 & .011 & .007 & .005 & $\mathrm{OCV}=1.63 \mathrm{v}$ & \\
\hline & Z, ohm & .404 & $\cdot 362$ & .320 & .252 & .214 & .196 & .186 & .181 & .178 & .175 & $\mathrm{SCC}=6.9 \mathrm{amp}$ & \\
\hline \multirow{3}{*}{4} & $\mathrm{R}$, ohm & 0.438 & 0.378 & 0.306 & 0.243 & 0.215 & 0.203 & 0.194 & 0.190 & 0.189 & 0.183 & After 6- & \multirow{3}{*}{37} \\
\hline & $x_{c}$, ohm & .095 & .121 & .115 & .075 & .053 & .033 & .018 & .012 & .009 & .006 & month & \\
\hline & Z, ohm & .448 & .397 & .327 & .254 & .221 & .206 & .195 & .190 & .189 & .183 & aglng & \\
\hline \multirow{3}{*}{4} & $R$, obm & 0.556 & 0.531 & 0.501 & 0.459 & 0.434 & 0.423 & 0.408 & 0.404 & 0.397 & 0.390 & After & \multirow{3}{*}{38} \\
\hline & $x_{c}, o h m$ & .038 & .056 & .060 & .057 & .044 & .032 & .021 & .016 & .012 & .008 & $\operatorname{LIF}^{\mathrm{a}}$ & \\
\hline & Z, ohm & .557 & .534 & .505 & .463 & .436 &. .424 & .409 & .404 & $\cdot 397$ & $\cdot 390$ & $\min =695$ & \\
\hline \multirow{3}{*}{4} & R, ohm & 0.993 & 0.966 & 0.947 & 0.911 & 0.878 & 0.855 & 0.819 & 0.794 & 0.775 & 0.751 & After $2.25-\Omega$ & \multirow{3}{*}{39} \\
\hline & $x_{c}, o h m$ & .051 & .061 & .054 & .060 & .061 & .059 & .055 & .051 & .046 & .033 & $\mathrm{GP} *$ test & \\
\hline & Z, ohm & .995 & .968 & .949 & .913 & .880 & .857 & .821 & .796 & .776 & .752 & $\min =497$ & \\
\hline \multirow{3}{*}{4} & $R$, ohm & 1.130 & 1.099 & 1.064 & 0.994 & 0.938 & 0.884 & 0.829 & 0.797 & 0.768 & 0.736 & After $4-\Omega$ & \multirow{3}{*}{40} \\
\hline & $x_{c}$, ohm & .080 & .102 & .101 & .110 & .110 & .102 & .086 & .073 & .062 & .052 & GP* test & \\
\hline & $\mathrm{Z}, \mathrm{ohm}$ & 1.133 & 1.104 & 1.069 & 1.000 & .945 & .890 & .834 & .803 & .770 & .738 & $\min =758$ & \\
\hline \multirow{3}{*}{5} & $R$, ohm & 0.696 & 0.314 & 0.271 & 0.204 & 0.180 & 0.166 & 0.153 & 0.149 & 0.145 & 0.141 & Fresh & \multirow{3}{*}{41} \\
\hline & $x_{c}, o h m$ & .546 & .415 & .247 & .128 & .077 & .047 & .026 & .017 & .012 & .010 & $\mathrm{OCV}=1.62 \mathrm{v}$ & \\
\hline & Z, ohm & .885 & .520 & $\cdot 366$ & .241 & .196 & .172 & .155 & .150 & .146 & .141 & $\mathrm{scc}=7.1 \mathrm{amg}$ & \\
\hline \multirow{3}{*}{5} & $R, o h m$ & 0.478 & 0.313 & 0.240 & 0.190 & 0.182 & 0.155 & 0.154 & 0.150 & 0.148 & 0.142 & After 6- & \multirow{3}{*}{42} \\
\hline & $x_{c}$, ohm & $\cdot 399$ & .265 & .165 & .088 & .056 & .036 & .020 & .014 & .010 & .008 & month & \\
\hline & Z, ohm & .623 & .410 & .291 & .209 & .190 & .159 & .155 & .151 & .148 & .142 & ag1ng & \\
\hline \multirow{3}{*}{5} & $R$, ohm & 0.431 & 0.349 & 0.307 & 0.286 & 0.278 & 0.276 & 0.271 & 0.268 & 0.260 & 0.257 & After & \multirow{3}{*}{43} \\
\hline & $x_{c}$, ohm & .194 & .137 & .085 & .044 & .028 & .019 & .013 & .010 & .009 & .009 & $\operatorname{LIF}^{\mathrm{a}}$ & \\
\hline & Z, ohm & .473 & $\cdot 375$ & .319 & .289 & .279 & .277 & .271 & .268 & .260 & .257 & $\min =823$ & \\
\hline \multirow{3}{*}{5} & $\mathrm{R}$, ohm & --- & 1.707 & 1.526 & 1.401 & 1.350 & 1.315 & 1.275 & 1.246 & 1.219 & 1.182 & After $2.25-\Omega$ & \multirow{3}{*}{44} \\
\hline & $\mathrm{x}_{\mathrm{c}}, \mathrm{ohm}$ & --- & 0.583 & 0.387 & 0.221 & 0.151 & 0.109 & 0.082 & 0.073 & 0.069 & 0.073 & GP* test & \\
\hline & Z, ohm & --- & 1.804 & 1.574 & 1.418 & 1.358 & 1.319 & 1.277 & 1.248 & 1.221 & 1.184 & $\min =526$ & \\
\hline \multirow{3}{*}{5} & R, ohm & 1.319 & 1.219 & 1.162 & 1.118 & 1.090 & 1.073 & 1.046 & 1.033 & 1.014 & --- & After $4-\Omega$ & \multirow{3}{*}{45} \\
\hline & $x_{c}$, ohm & 0.354 & 0.230 & 0.151 & 0.093 & 0.068 & 0.053 & 0.045 & 0.043 & 0.043 & --- & GP* test & \\
\hline & Z, ohm & 1.365 & 1.240 & 1.172 & 1.122 & 1.092 & 1.074 & 1.047 & 1.034 & 1.015 & --- & $\min =904$ & \\
\hline
\end{tabular}

a - to a 0.9 -volt cutoff

b - when more than one test, results were obtalned on separate cells within same production lot

$3_{1}$ and $3_{2}$ were of different production lots 
Table 4. Impedance Data on D-size Industrial Leclanche Dry Cells; Average of 6 Cells in Each Case.

[D Cells: diameter, $11 / 4$ inches; can height, 2 1/4 inches]

\begin{tabular}{|c|c|c|c|c|c|c|c|c|c|c|c|c|c|}
\hline Brand & $\begin{array}{l}\text { Resistance, capa- } \\
\text { citive reactance, } \\
\text { and impedance }\end{array}$ & 50 & 100 & 200 & $\begin{array}{r}\text { Freque } \\
500\end{array}$ & $\begin{array}{l}\text { ney, Cy } \\
1,000\end{array}$ & $\begin{array}{l}\text { cles pe } \\
2,000\end{array}$ & 5,000 & 10,000 & 20,000 & 50,000 & $\begin{array}{l}\text { Condition } \\
\text { of Cell }\end{array}$ & $\begin{array}{l}\text { Figure } \\
\text { Number }\end{array}$ \\
\hline \multirow{3}{*}{1} & $R$, ohm & 0.314 & 0.301 & 0.285 & 0.254 & 0.231 & 0.219 & 0.207 & 0.199 & 0.196 & 0.191 & Fresh & \multirow{3}{*}{46} \\
\hline & $x_{c}$, ohm & .018 & .028 & .036 & .040 & .034 & .026 & .018 & .013 & .007 & .006 & $\mathrm{OCV}=1.62 \mathrm{v}$ & \\
\hline & Z, ohm & .315 & .302 & .287 & .257 & .234 & .220 & .208 & .199 & .196 & .191 & $\mathrm{SCC}=6.8 \mathrm{amp}$ & \\
\hline \multirow{3}{*}{1} & $R$, ohm & 0.377 & 0.348 & 0.307 & 0.262 & 0.242 & 0.225 & 0.217 & 0.211 & 0.207 & 0.203 & After 3- & \multirow{3}{*}{47} \\
\hline & $x_{c}$, ohm & .053 & .061 & .071 & .057 & .041 & .028 & .019 & .014 & .011 & .008 & month & \\
\hline & Z, ohm & .381 & .353 & $\cdot 315$ & .268 & .245 & .227 & .218 & .211 & .207 & .203 & aging & \\
\hline \multirow{3}{*}{1} & $R$, ohm & 1.319 & 1.266 & 1.200 & 1.079 & 0.972 & 0.873 & 0.778 & 0.732 & 0.700 & 0.663 & After & \multirow{3}{*}{48} \\
\hline & $x_{c}$, ohm & 0.119 & 0.140 & 0.162 & 0.195 & .199 & .172 & .124 & .095 & .072 & .053 & $I I F^{a}$ & \\
\hline & Z, ohm & 1.324 & 1.274 & 1.211 & 1.097 & .992 & .890 & .788 & .738 & .704 & .665 & $\min =913$ & \\
\hline \multirow{3}{*}{2} & $R$, ohm & 0.363 & 0.336 & 0.294 & 0.242 & 0.222 & 0.208 & 0.197 & 0.192 & 0.187 & 0.183 & Fresh & \multirow{3}{*}{49} \\
\hline & $x_{c}, o h m$ & .045 & .066 & .073 & .057 & .041 & .028 & .016 & .012 & .007 & .005 & $O C V=1.66 \mathrm{v}$ & \\
\hline & Z, ohm & .366 & $\cdot 342$ & .303 & .249 & .226 & .210 & .198 & .192 & .187 & .183 & $\mathrm{sCC}=6.7 \mathrm{amp}$ & \\
\hline \multirow{3}{*}{2} & $\mathrm{R}$, ohm & 0.506 & 0.368 & 0.286 & 0.243 & 0.229 & 0.214 & 0.207 & 0.200 & 0.198 & 0.194 & After 3- & \multirow{3}{*}{50} \\
\hline & $x_{c}$, ohm & .230 & .203 & .138 & .072 & .047 & .030 & .020 & .014 & .009 & .005 & month & \\
\hline & Z, ohm & .556 & .420 & $\cdot 318$ & .253 & .233 & .216 & .208 & .200 & .198 & .194 & aging & \\
\hline \multirow{3}{*}{2} & $\mathrm{R}$, ohm & 0.584 & 0.547 & 0.516 & 0.478 & 0.459 & 0.449 & 0.435 & 0.429 & 0.419 & 0.418 & After & \multirow{3}{*}{51} \\
\hline & $\mathrm{x}_{\mathrm{c}}$, ohm & .072 & .065 & .060 & .044 & .035 & .027 & .020 & .014 & .010 & .005 & $L I F^{a}$ & \\
\hline & Z, ohm & .589 & .551 & .519 & .480 & .460 & .450 & .435 & .429 & .419 & .418 & $\min =891$ & \\
\hline \multirow{3}{*}{2} & $\mathrm{R}$, ohm & --- & 0.466 & 0.427 & 0.401 & 0.385 & 0.374 & 0.367 & 0.361 & 0.356 & 0.347 & After & \multirow{3}{*}{$\cdot 52$} \\
\hline & $x_{c}, o h m$ & --- & .093 & .070 & .041 & .031 & .023 & .017 & .013 & .008 & .009 & $\mathrm{HIF} \mathrm{F}^{\mathrm{a}, \mathrm{b}}$ & \\
\hline & Z, ohm & -- & .475 & .433 & .403 & .386 & .375 & .367 & .361 & .356 & .349 & $-1 n=775$ & \\
\hline
\end{tabular}

a - to a 0.9 -volt cutoff

b - obtained on similar celk within same production lot 
Table 5. Impedance Data on 45-volt Leclanché Dry Batteries; Average of Either 2 or 3 Batteries in Each Case. [Composed of Flat Cells of Varlous Sizes*; all Batteries 1 to 4 Months 0ld]

\begin{tabular}{|c|c|c|c|c|c|c|c|c|c|c|c|c|}
\hline Brand & $\begin{array}{l}\text { Resistance, capa- } \\
\text { c1tive reactance, } \\
\text { and impedance }\end{array}$ & 50 & 100 & 200 & $\begin{array}{l}\text { Frequen } \\
500\end{array}$ & $\begin{array}{l}c y, \text { Cyc1 } \\
1,000\end{array}$ & $\begin{array}{l}\text { es per } \mathrm{s} \\
2,000\end{array}$ & 5,000 & 10,000 & 20,000 & 50,000 & $\begin{array}{l}\text { Cell } \\
\text { Size }\end{array}$ \\
\hline \multirow{3}{*}{6} & $R$, ohms & 672.90 & 627.93 & 564.46 & 463.33 & 396.19 & 346.47 & 302.59 & $277 \cdot 36$ & 256.95 & -- & \multirow{3}{*}{ F20 } \\
\hline & $x_{c}$, ohms & 105.46 & 133.45 & 143.79 & 143.68 & 124.49 & 98.00 & 72.57 & 56.87 & 41.51 & -- & \\
\hline & z, ohms & 681.11 & 641.95 & 582.48 & 485.10 & 415.29 & 360.06 & 311.17 & 282.95 & 260.28 & -- & \\
\hline \multirow{3}{*}{6} & R, ohms & 375.00 & 224.89 & 154.78 & $106 \cdot 38$ & 82.48 & 73.24 & 62.86 & $57 \cdot 76$ & 54.04 & 50.23 & \multirow{3}{*}{$\mathrm{F} 4 \mathrm{O}$} \\
\hline & $\mathrm{x}_{\mathrm{c}}$, ohms & 491.59 & 336.87 & 204.33 & 106.47 & 65.69 & 40.95 & 22.90 & 15.41 & 10.83 & 7.44 & \\
\hline & Z, ohms & 618.29 & 405.04 & 256.33 & 150.51 & 105.44 & 83.91 & 66.90 & 59.78 & 55.11 & 50.78 & \\
\hline \multirow{3}{*}{6} & $R$, ohms & 131.51 & $89 \cdot 37$ & 58.08 & $35 \cdot 34$ & $27 \cdot 36$ & 22.79 & 18.95 & 16.86 & 15.17 & 13.52 & \multirow{3}{*}{$F 60^{a}$} \\
\hline & $\mathrm{x}_{\mathrm{c}}$, ohms & 85.21 & 74.44 & 55.88 & $32 \cdot 30$ & 20.58 & 13.26 & 8.00 & 5.70 & 4.13 & 2.60 & \\
\hline & Z, ohms & 156.70 & 116.31 & 80.60 & 47.88 & 34.23 & 26.37 & 20.57 & 17.80 & 15.72 & 13.77 & \\
\hline \multirow{3}{*}{6} & $\mathrm{R}$, ohms & 65.07 & $47 \cdot 37$ & 32.40 & 19.50 & 14.87 & 12.63 & 10.91 & 9.94 & 9.16 & 8.35 & \multirow{3}{*}{ F95 ${ }^{\mathrm{b}}$} \\
\hline & $\mathrm{x}_{\mathrm{c}}$, ohms & 31.75 & 31.39 & 26.33 & 16.59 & 10.49 & 6.54 & 3.79 & 2.72 & 1.95 & 1.13 & \\
\hline & Z, ohms & 72.40 & 56.83 & 41.75 & 25.60 & 18.20 & 14.22 & 11.55 & $10 \cdot 30$ & $9 \cdot 37$ & 8.54 & \\
\hline \multirow{3}{*}{6} & $R$, ohms & 46.47 & 41.82 & 38.04 & 33.65 & 30.54 & 27.59 & 24.14 & 21.92 & 19.98 & 17.49 & \multirow{3}{*}{ F100 } \\
\hline & $x_{c}$, ohms & 0.85 & 4.11 & 5.87 & 6.55 & 6.59 & 6.19 & 5.43 & 4.80 & 4.15 & 3.22 & \\
\hline & Z, ohms & 46.48 & 42.02 & 38.49 & 34.28 & 31.24 & 28.28 & 24.74 & 22.44 & 20.41 & $17 \cdot 78$ & \\
\hline \multirow{3}{*}{7} & $R$, ohms & 331.33 & 222.29 & 161.03 & 136.17 & 128.24 & 123.60 & $120 \cdot 38$ & 118.75 & 116.82 & 114.84 & \multirow{3}{*}{ F२O } \\
\hline & $\mathrm{x}_{c}$, ohms & 356.90 & 236.90 & 136.68 & 62.72 & 36.35 & 20.48 & 10.43 & 6.97 & $5 \cdot 38$ & 4.86 & \\
\hline & Z, ohms & 486.99 & 324.86 & 211.21 & 149.92 & 1.33 .29 & 125.28 & 120.83 & 118.96 & 116.94 & 114.94 & \\
\hline \multirow{3}{*}{7} & $\mathrm{R}$, ohms & 166.50 & 107.63 & 81.02 & 66.97 & 61.57 & 57.12 & 53.08 & 50.81 & 48.74 & 45.47 & \multirow{3}{*}{ F30 } \\
\hline & $x_{c}$, ohms & 256.63 & 148.75 & 79.27 & 40.88 & 24.67 & 15.94 & 9.48 & 7.12 & 5.93 & 4.94 & \\
\hline & Z, ohms & 348.29 & 183.60 & 113.35 & 78.46 & 66.33 & $59 \cdot 30$ & 53.92 & 50.10 & 49.10 & 45.74 & \\
\hline \multirow{3}{*}{7} & $R$, ohms & 85.29 & 57.43 & 46.87 & 41.00 & 38.63 & 37.14 & 35.68 & 34.63 & 33.54 & 31.98 & \multirow{3}{*}{ F60 } \\
\hline & $\mathrm{x}_{\mathrm{c}}$, ohms & 78.60 & 48.54 & 28.22 & 14.11 & 8.63 & 5.53 & 3.67 & 3.13 & 2.91 & 2.88 & \\
\hline & $\mathrm{z}$, ohms & 115.99 & 75.19 & 54.71 & $43 \cdot 36$ & 39.58 & $37 \cdot 55$ & 35.87 & 34.77 & 33.67 & 32.11 & \\
\hline \multirow{3}{*}{7} & $R$, ohms & 37.80 & 27.00 & 21.17 & 16.91 & 14.92 & 13.66 & 12.62 & 12.02 & 11.48 & 10.73 & \multirow{3}{*}{ F95 } \\
\hline & $x_{c}$, ohms & 13.59 & 12.77 & 9.75 & 6.34 & 4.49 & 3.09 & 2.04 & 1.67 & 1.46 & 1.34 & \\
\hline & z, ohms & 40.17 & 29.87 & $23 \cdot 30$ & 18.06 & 15.58 & 14.00 & 12.78 & 12.14 & 17.57 & 10.81 & \\
\hline \multirow{3}{*}{7} & $R$, ohms & 30.53 & 22.27 & 18.38 & 15.47 & 14.49 & 13.89 & 13.20 & 12.68 & 12.12 & 11.34 & \multirow{3}{*}{ F100 } \\
\hline & $x_{c}$, ohms & 6.84 & 8.17 & 6.01 & 3.61 & 2.45 & 1.79 & 1.41 & 1.33 & 1.29 & 1.25 & \\
\hline & $\mathrm{z}$, orms & 31.29 & 23.72 & $19 \cdot 34$ & 15.89 & 14.70 & 14.00 & 13.27 & 12.75 & 12.19 & 11.41 & \\
\hline
\end{tabular}

* Cell size Length, Inches Width, Inches Thickness, Inches

\begin{tabular}{|c|c|c|c|}
\hline jי20 & $15 / 16$ & $17 / 32$ & 0.11 \\
\hline F30 & $11 / 4$ & $27 / 32$ & .13 \\
\hline F40 & $11 / 4$ & $27 / 32$ & .21 \\
\hline F60 & $11 / 4$ & $11 / 4$ & .15 \\
\hline F95** & $23 / 8$ & $13 / 4$ & .28 \\
\hline F100 & $23 / 8$ & $125 / 32$ & .41 \\
\hline
\end{tabular}

* new size not included in NBS Handbook 71 [1]

a - cylindrical AA-size cells

b - cylindrical B-size cells; B cells have a diameter of $3 / 4$ inch and a can helght of $21 / 8$ inches. 
Table 6. Comparison of Output with Internal Resistance, Impedance, Open-circuit Voltage, and Short-circuit Current

[In increasing order for internal resistance within cell size]

\begin{tabular}{|c|c|c|c|c|c|c|c|}
\hline Cell & $\begin{array}{l}\mathrm{R}^{*} \\
\mathrm{ohm}\end{array}$ & $\begin{array}{l}\mathrm{Z}^{*} \\
\mathrm{ohm}\end{array}$ & $\begin{array}{c}\text { OCV } \\
\text { volts }\end{array}$ & $\begin{array}{c}\text { SCC } \\
\text { amperes }\end{array}$ & $\begin{array}{l}\text { Test No. } 1 \\
\text { minutes }\end{array}$ & $\begin{array}{l}\text { Test No. } 2 \\
\text { minutes }\end{array}$ & $\begin{array}{c}\text { Test No. } 3 \\
\text { minutes }\end{array}$ \\
\hline AA 4 & 0.199 & 0.247 & 1.62 & 6.1 & 128 & --- & -- \\
\hline AA3 & .292 & .340 & 1.56 & 4.1 & 102 & --- & --- \\
\hline AAI & .330 & .361 & 1.65 & 3.7 & 148 & --- & --- \\
\hline AA2 & .361 & .376 & 1.61 & 3.5 & 144 & --- & --- \\
\hline $\mathrm{Cl}$ & 0.259 & 0.266 & 1.60 & 5.4 & 430 & --- & --- \\
\hline C3 & .305 & .346 & 1.61 & $5 \cdot 3$ & 420 & -.- & --- \\
\hline $\mathrm{C} 4$ & .336 & .342 & 1.59 & 4.0 & 462 & -- & -.- \\
\hline $\mathrm{C} 2$ & .374 & .381 & 1.56 & 3.8 & 406 & --- & --- \\
\hline D5 & 0.180 & 0.196 & 1.62 & 7.1 & 904 & $526^{b}$ & 823 \\
\hline $\mathrm{DI}$ & .189 & .192 & 1.58 & 7.1 & 584 & 444 & --- \\
\hline D4 & .208 & .214 & 1.63 & 6.9 & 758 & 497 & 695 \\
\hline $\mathrm{D} 2$ & 0.196 & 0.199 & 1.56 & 6.9 & --- & 533 & 642 \\
\hline $\mathrm{D}_{1}$ & .224 & .226 & 1.68 & $7 \cdot 3$ & --- & --- & 693 \\
\hline $\mathrm{D}_{2}$ & .233 & .269 & 1.61 & 6.5 & --- & 538 & --- \\
\hline $\mathrm{D} 2^{\mathrm{a}}$ & 0.222 & 0.226 & 1.66 & 6.7 & --- & --- & 891 \\
\hline $\mathrm{DI}^{\mathrm{a}}$ & .231 & .234 & 1.62 & 6.8 & --- & --- & 913 \\
\hline
\end{tabular}

* - at $1000 \mathrm{cps}$

a - industrial type cell

b - when more than one test, results were obtained on a separate cells within same production lot. 


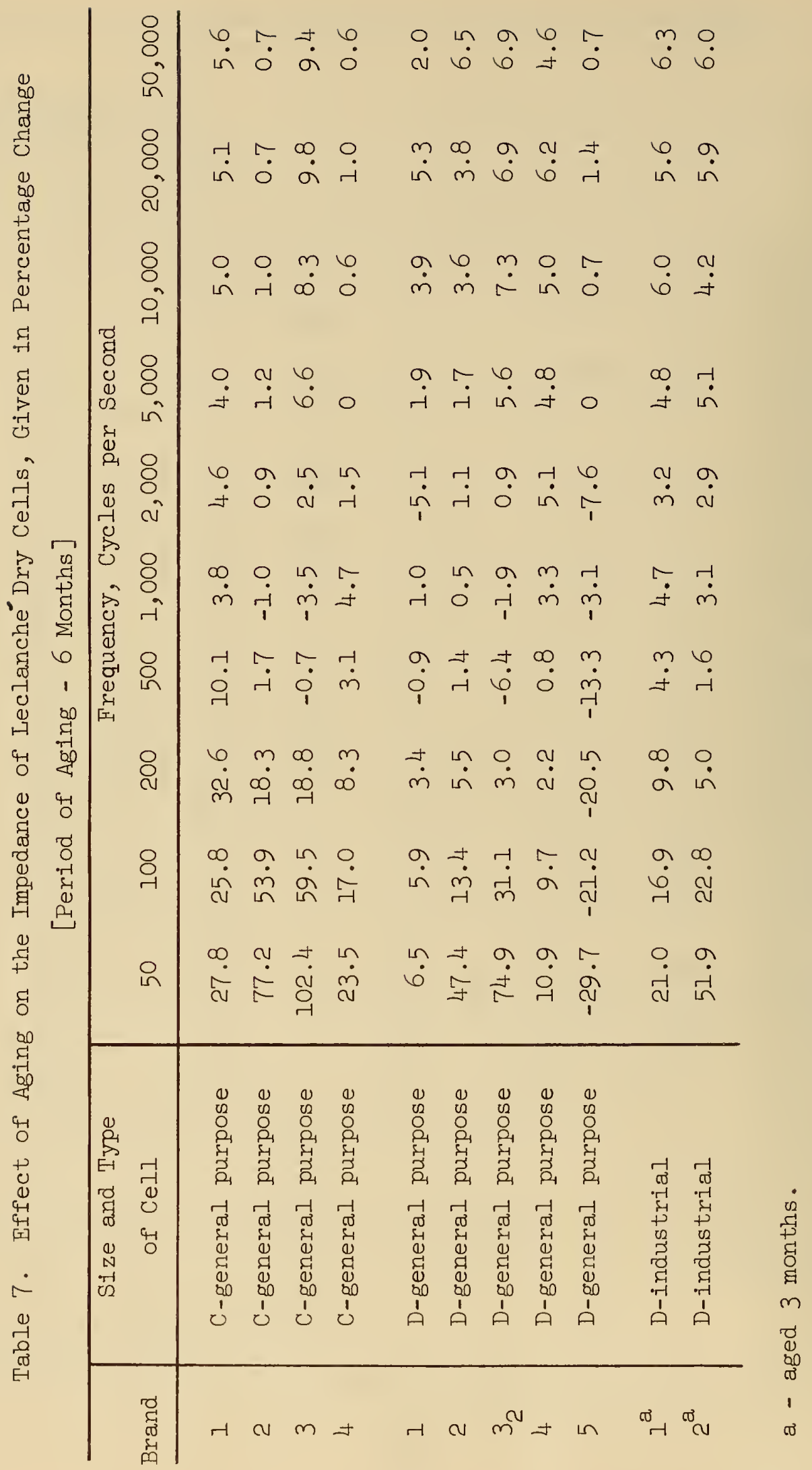


Table 8. Effect of Various Types of Discharge on the Impedance of Leclanché Dry Cells, given in Percentage Change

\begin{tabular}{|c|c|c|c|c|c|c|c|c|c|c|c|c|}
\hline \multirow[b]{2}{*}{ Brand } & \multirow[b]{2}{*}{ Size of Cell* } & \multicolumn{10}{|c|}{ Frequency, Cycles per Second } & \multirow{2}{*}{$\begin{array}{l}\text { Minutes } \\
\text { on } \\
\text { Discharge }\end{array}$} \\
\hline & & 50 & 100 & 200 & 500 & 1,000 & 2,000 & 5,000 & 10,000 & 20,000 & 50,000 & \\
\hline & & \multicolumn{10}{|c|}{ General-purpose 4-ohm Intermlttent Test } & \\
\hline 1 & $\mathrm{AA}$ & -21 & 7 & 56 & 127 & 143 & 133 & 100 & 81 & 69 & 61 & 148 \\
\hline 2 & AA & -26 & -5 & 27 & 74 & 93 & 102 & 105 & 102 & 109 & 109 & 144 \\
\hline 3 & $\mathrm{AA}$ & -37 & -1 & 52 & 151 & 227 & 274 & 290 & 295 & 297 & 296 & 102 \\
\hline 4 & $A A$ & -21 & -1 & 49 & 163 & 252 & 308 & 305 & 286 & 259 & 259 & 128 \\
\hline 1 & C & 177 & 170 & 224 & 235 & 255 & 266 & 259 & 260 & 261 & 249 & 430 \\
\hline 2 & C & 125 & 121 & 121 & 150 & 158 & 169 & 179 & 187 & 187 & 193 & 406 \\
\hline 3 & C & 29 & 34 & 49 & 113 & 176 & 238 & 283 & 303 & 304 & 303 & 420 \\
\hline 4 & C & 144 & 164 & 206 & 262 & 302 & 304 & 306 & 311 & 308 & 306 & 462 \\
\hline 1 & D & 410 & 416 & 4.14 & 424 & 445 & 442 & 420 & 409 & 397 & 373 & 584 \\
\hline 4 & D & 180 & 205 & 234 & 297 & 342 & 354 & 348 & 344 & 333 & 322 & 758 \\
\hline 5 & $D$ & 54 & 138 & 220 & 366 & 457 & 524 & 575 & 589 & 595 & --- & 904 \\
\hline & & \multicolumn{10}{|c|}{ General-purpose 2.25-ohm Intermittent Test } & \\
\hline 1 & $\mathrm{D}$ & 380 & 384 & 378 & 392 & 408 & 380 & 398 & 395 & 377 & 360 & 444 \\
\hline 2 & D & 129 & 112 & 149 & 196 & 220 & 243 & 263 & 277 & 288 & 295 & 533 \\
\hline 32 & $\mathrm{D}$ & -12 & -6 & 16 & 81 & 144 & 183 & 215 & 218 & 222 & 215 & 538 \\
\hline 4 & $\mathrm{D}$ & 146 & 167 & 197 & 262 & 321 & 337 & 341 & 340 & 336 & 330 & 497 \\
\hline 5 & $\mathrm{D}$ & -- & 247 & 330 & 488 & 593 & 667 & 724 & 732 & 736 & 740 & 526 \\
\hline & & \multicolumn{10}{|c|}{ Light-industrial Flashlight-cell Test (LIF) } & \\
\hline 1 & D & 193 & 191 & 184 & 184 & 197 & 202 & 202 & 202 & 200 & 196 & -- \\
\hline 2 & D & -1 & -4 & 10 & 30 & 39 & 48 & 58 & 62 & 67 & 67 & 642 \\
\hline $3_{1}$ & $D$ & 91 & 95 & 135 & 114 & 174 & 124 & 149 & 150 & 149 & 154 & 693 \\
\hline 4 & $D$ & 38 & 45 & 58 & 84 & 104 & 116 & 120 & 123 & 123 & 123 & 695 \\
\hline 5 & D & -47 & -28 & -13 & 20 & 42 & 61 & 75 & 79 & 78 & 82 & 823 \\
\hline 1 & $D^{\mathrm{a}}$ & 320 & 322 & 322 & 327 & 324 & 305 & 279 & 271 & 259 & 248 & 913 \\
\hline \multirow[t]{2}{*}{2} & $D^{\mathrm{a}}$ & 61 & 61 & 71 & 93 & 104 & 114 & 120 & 123 & 124 & 128 & 891 \\
\hline & & \multicolumn{10}{|c|}{ Heavy-industrial Flashlight-cell Test ( $\mathrm{HIF}$ ) } & \\
\hline 2 & $D^{a}$ & --- & 39 & 43 & 62 & 71 & 79 & 85 & 88 & 90 & 91 & 775 \\
\hline
\end{tabular}

* - All cells were of the general-purpose type except those marked with a superscript a.

a - Industrial type cells. 


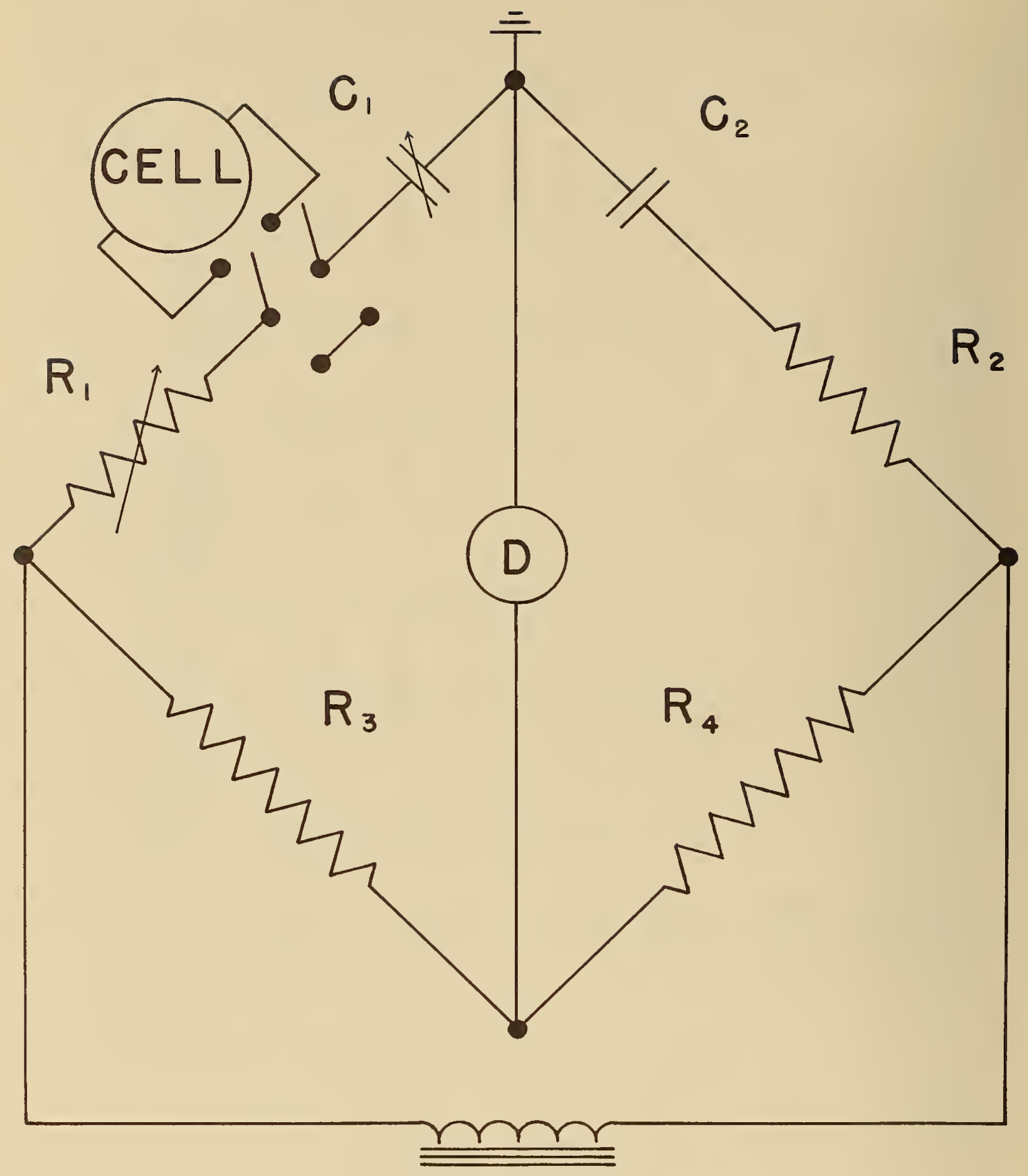

FIG. I WIEN IMPEDANCE BRIDGE CIRCUIT 


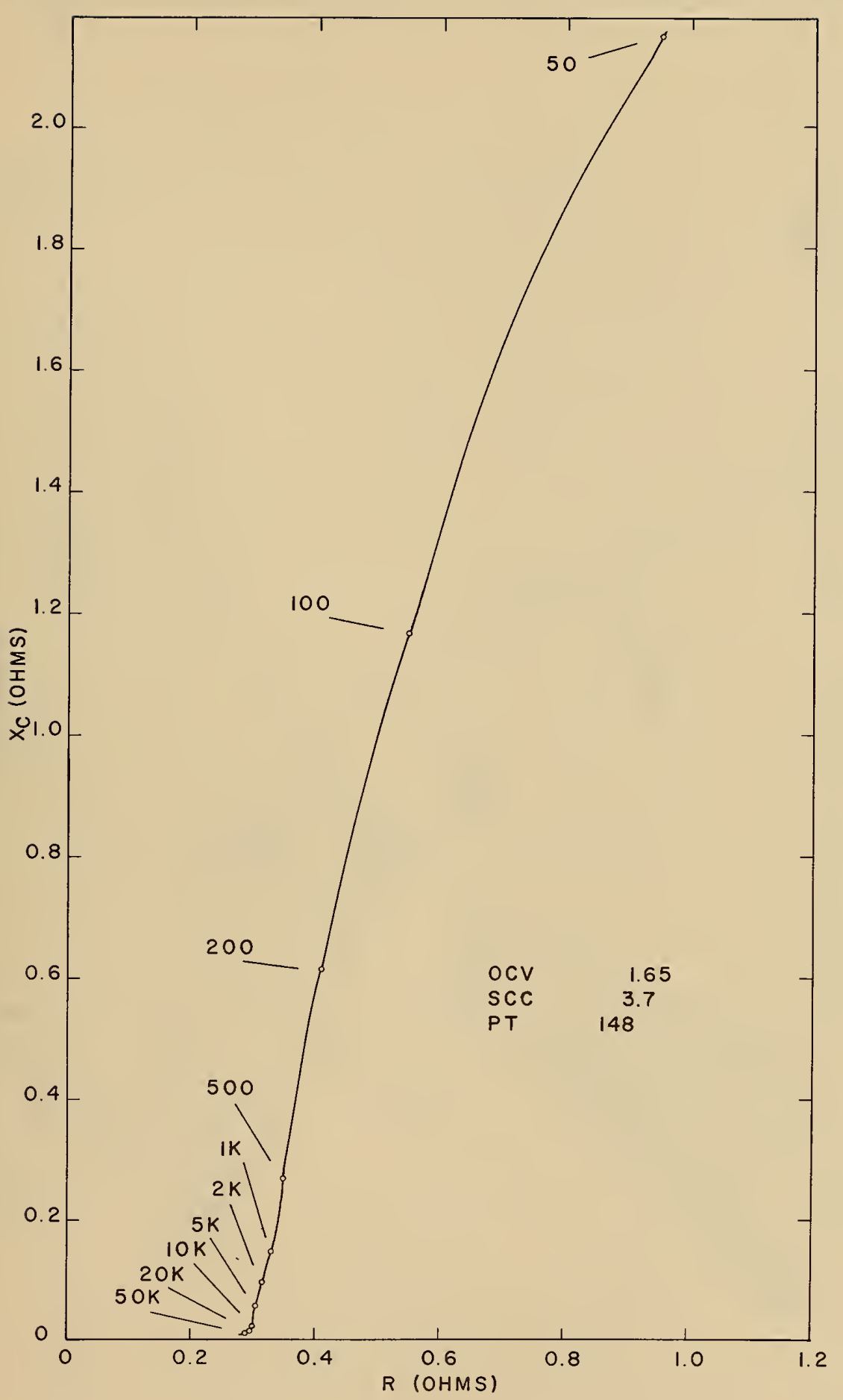

FIG. 2 RESISTANCE-REACTANCE CURVE OF AA-SIZE CELLS OF BRAND I BEFORE DISCHARGE 


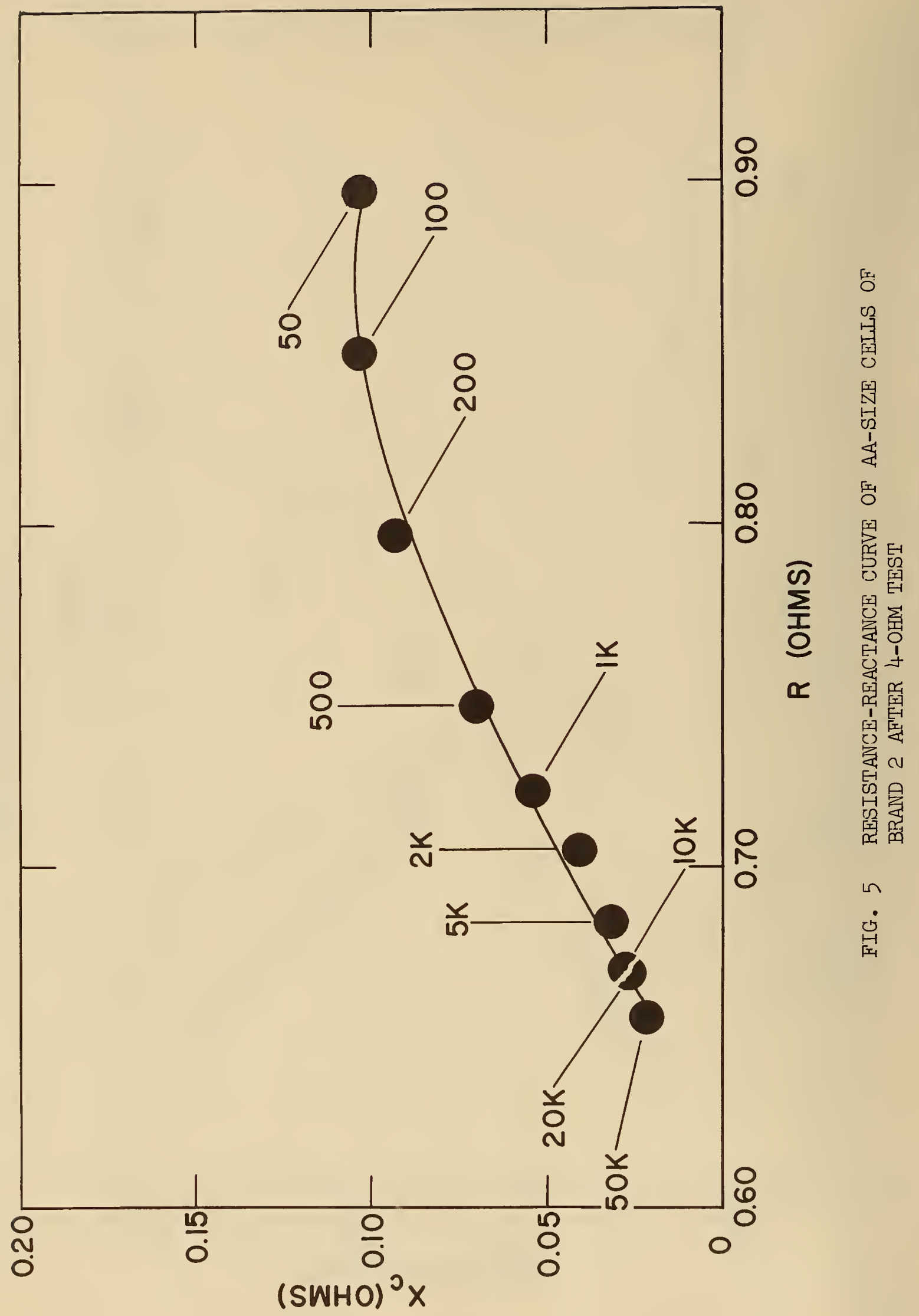




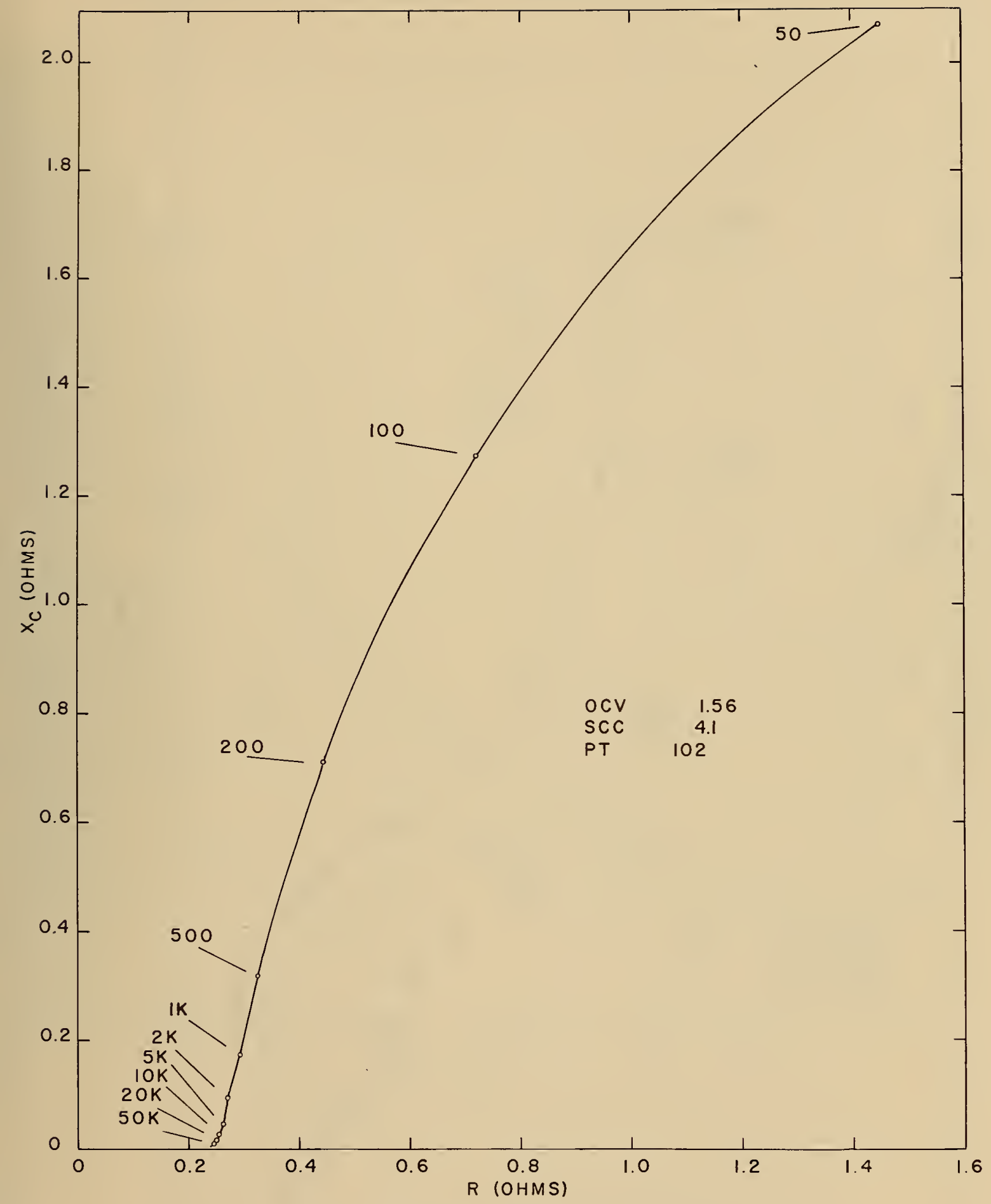

FIG. 6 RESISTANCE-REACTANCE CURVE OF AA-SIZE CELLS OF BRAND 3 BEFORE DISCHARGE 


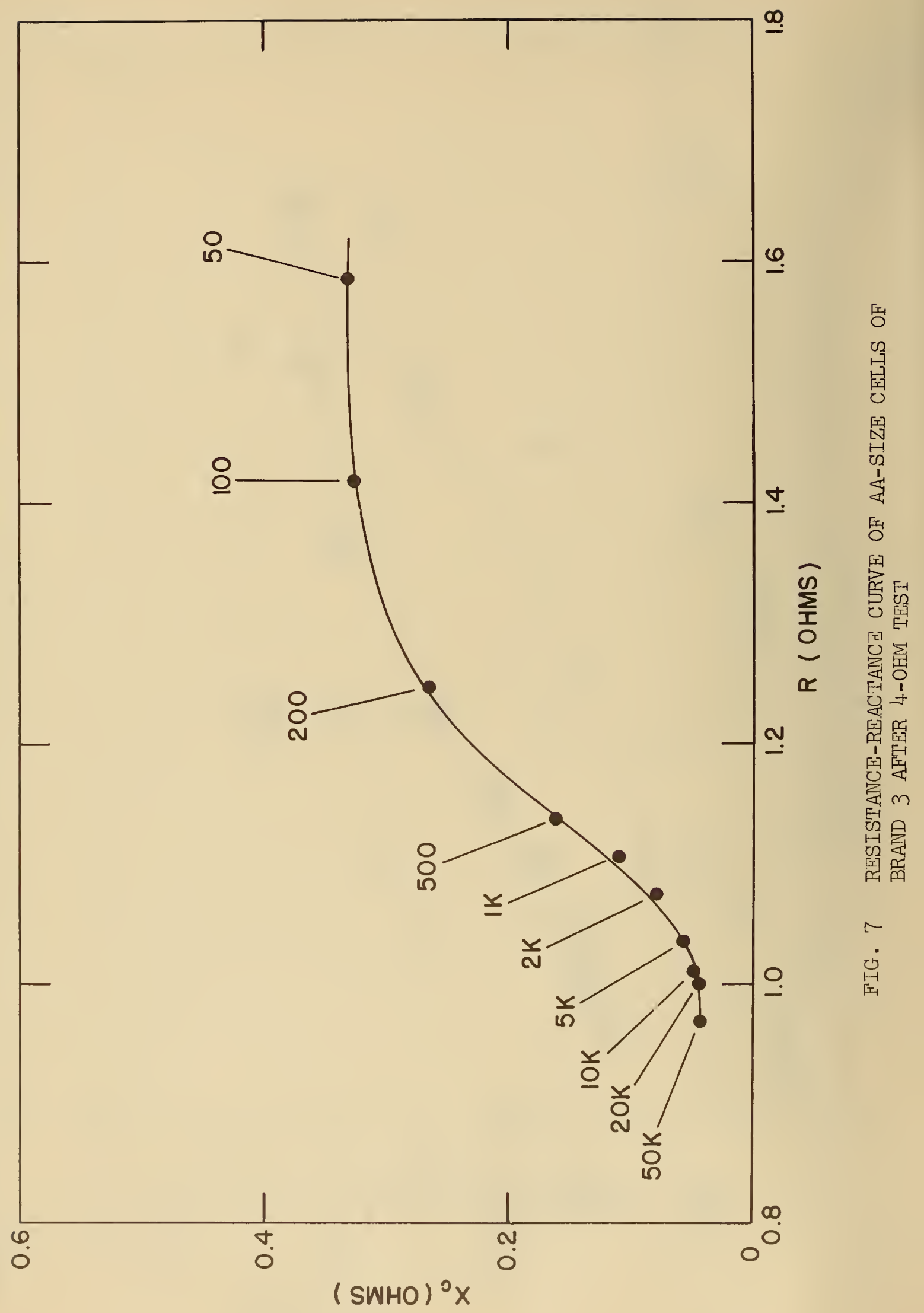




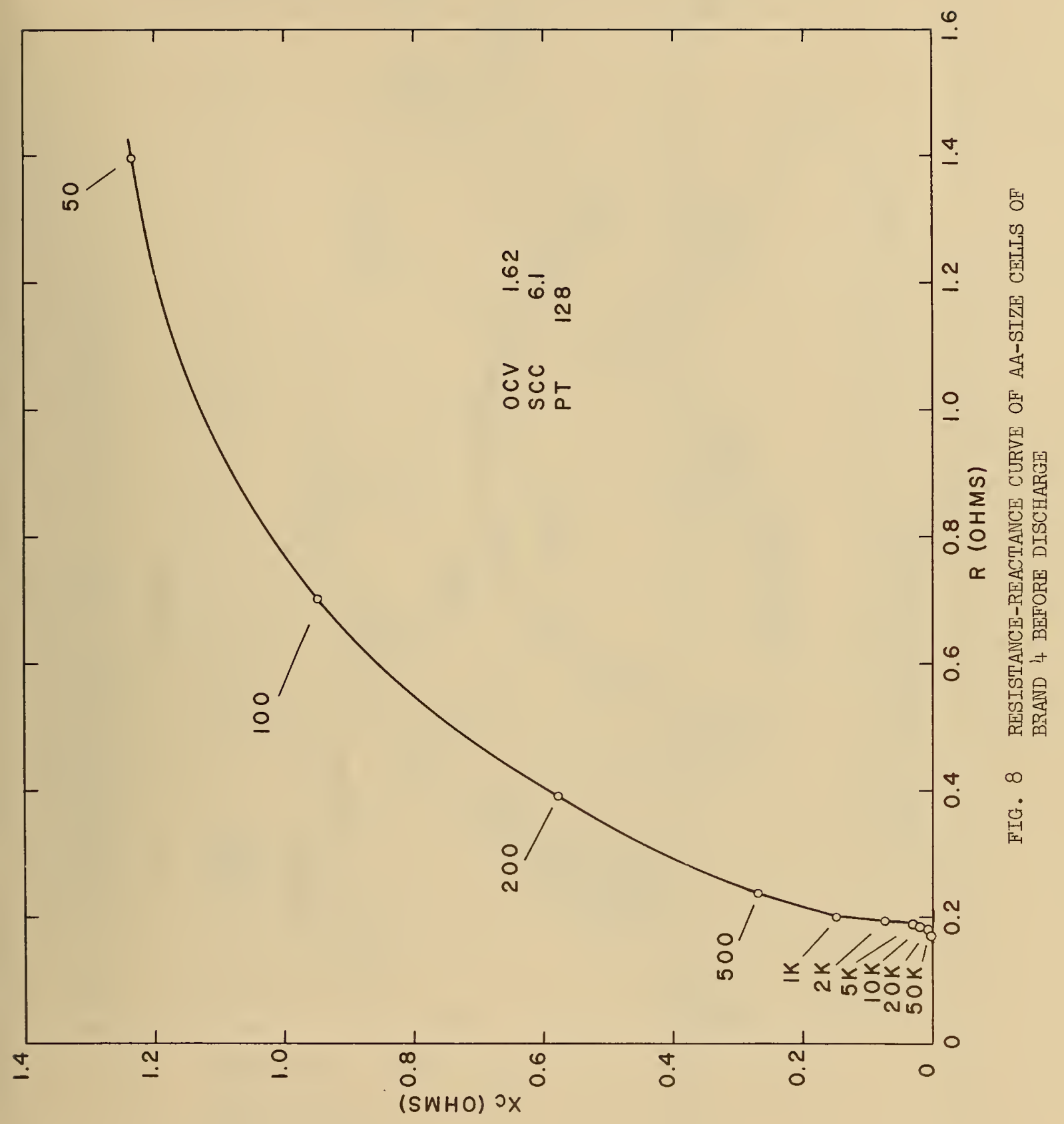




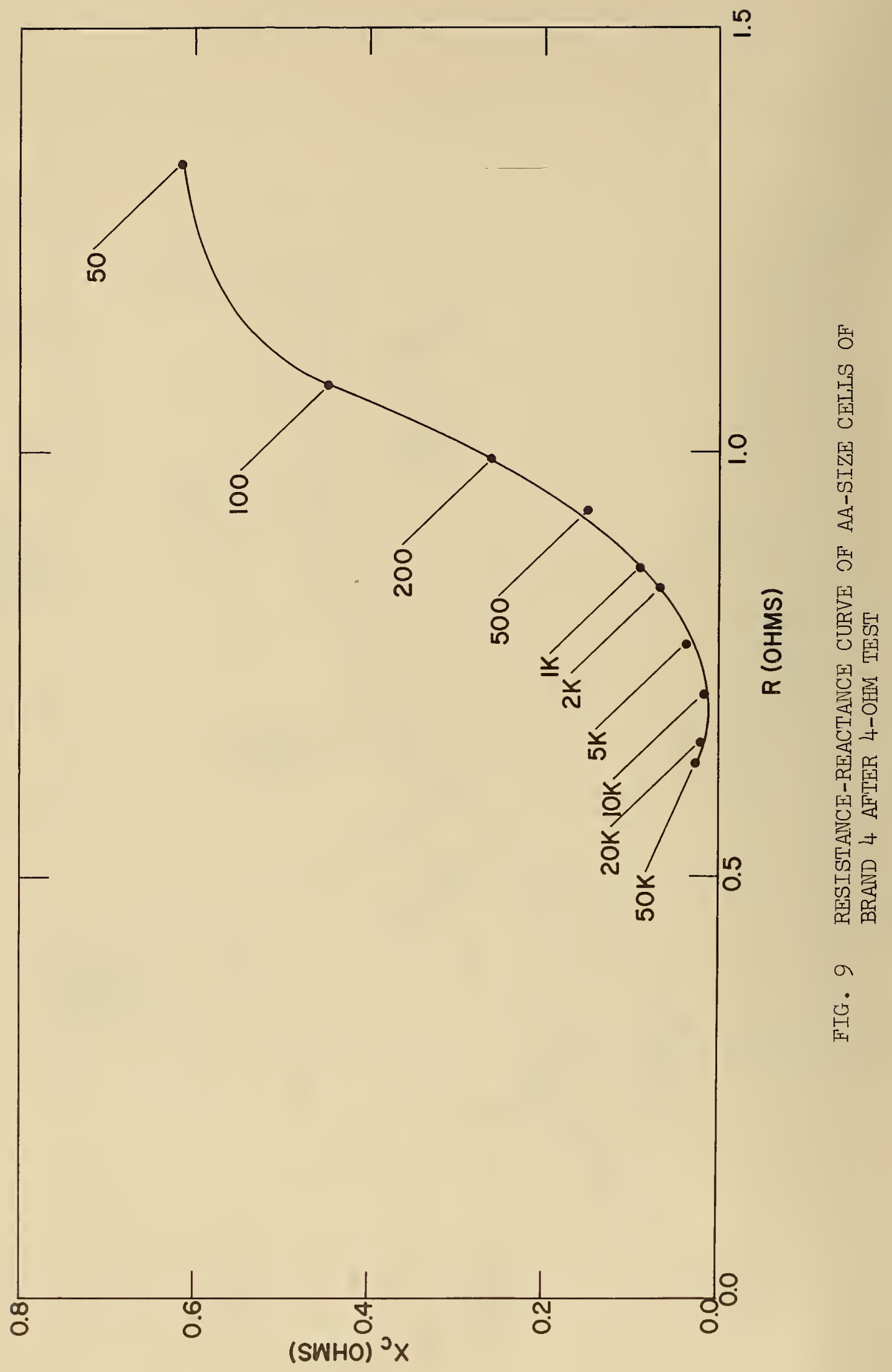




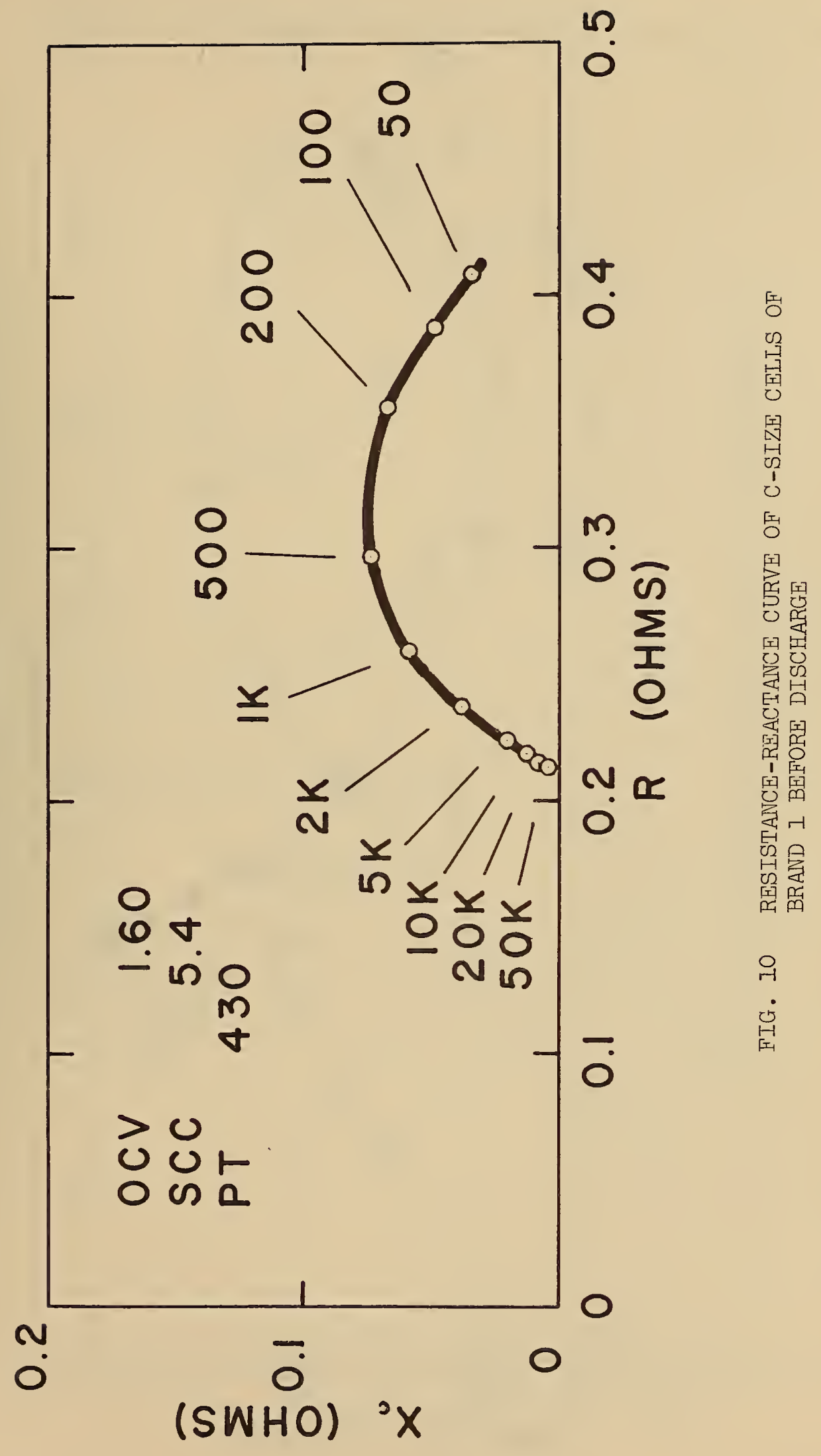




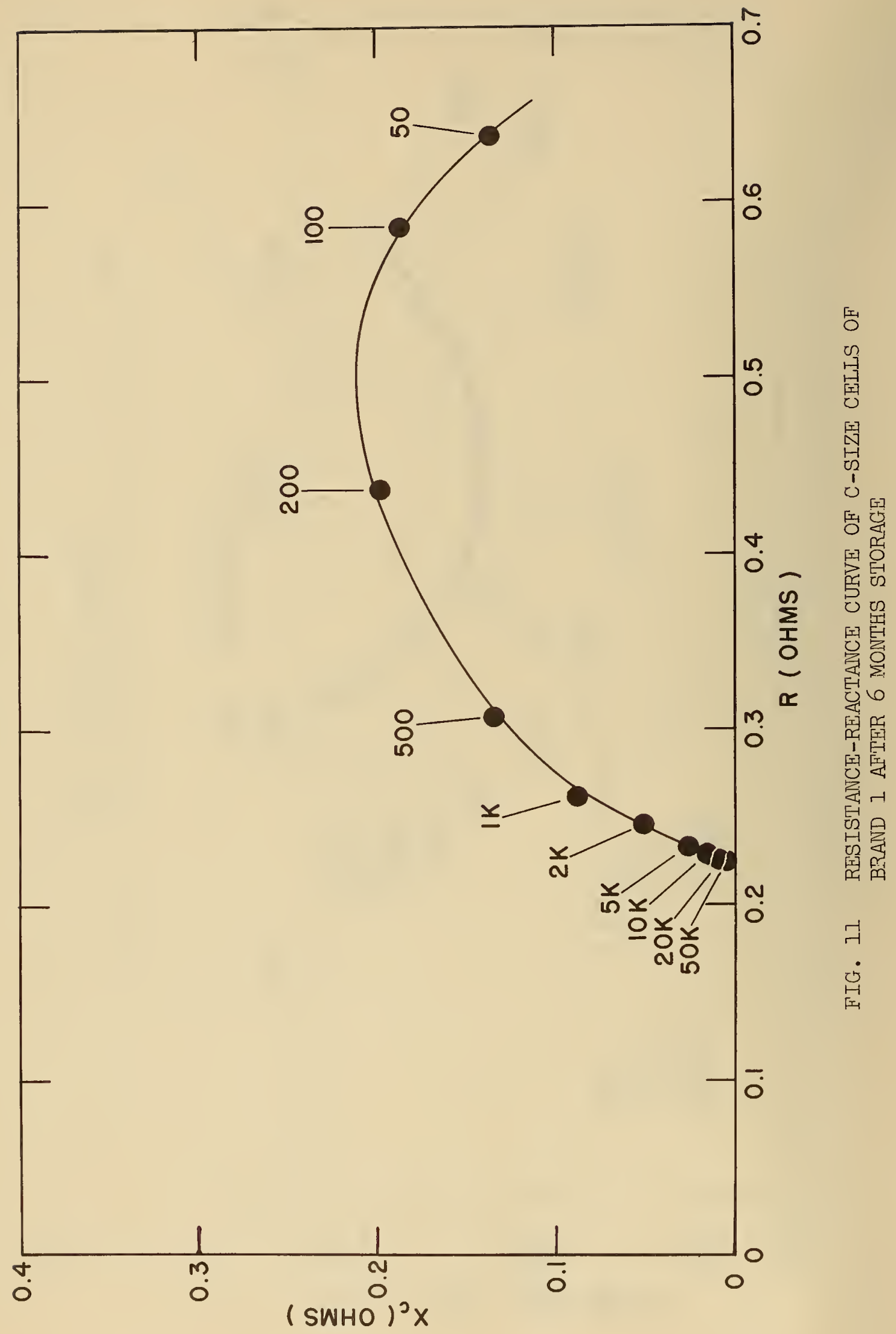




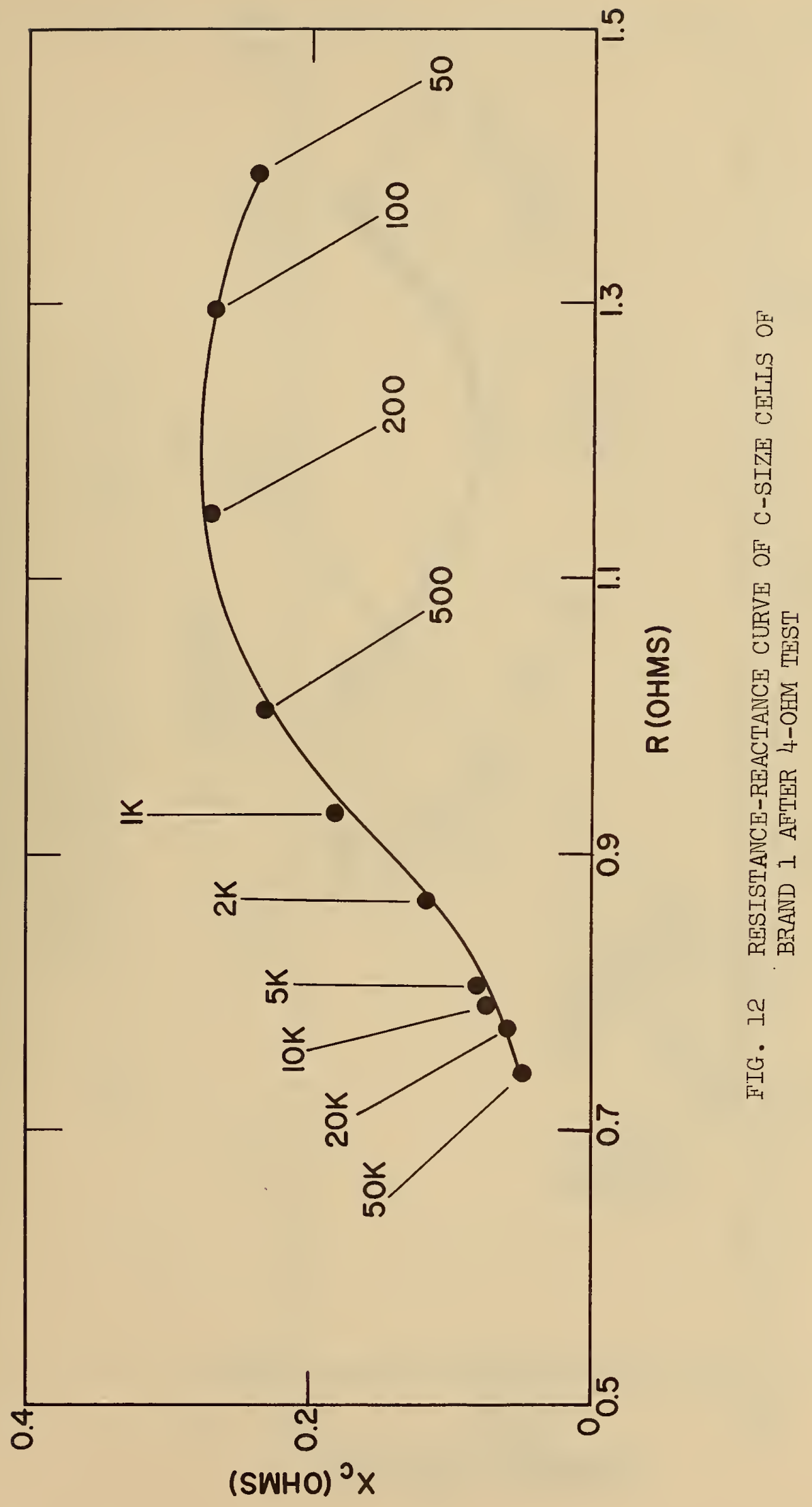




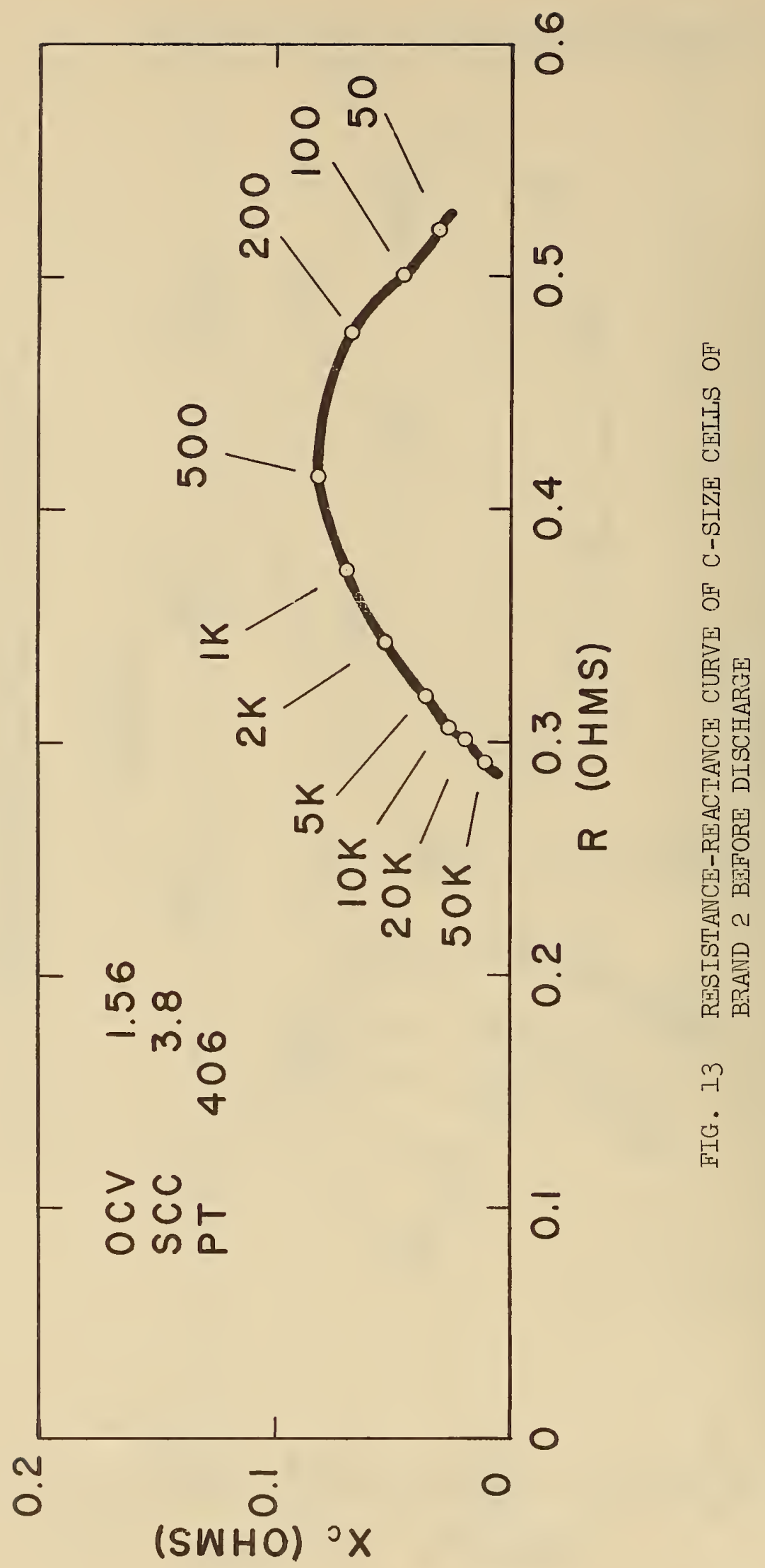




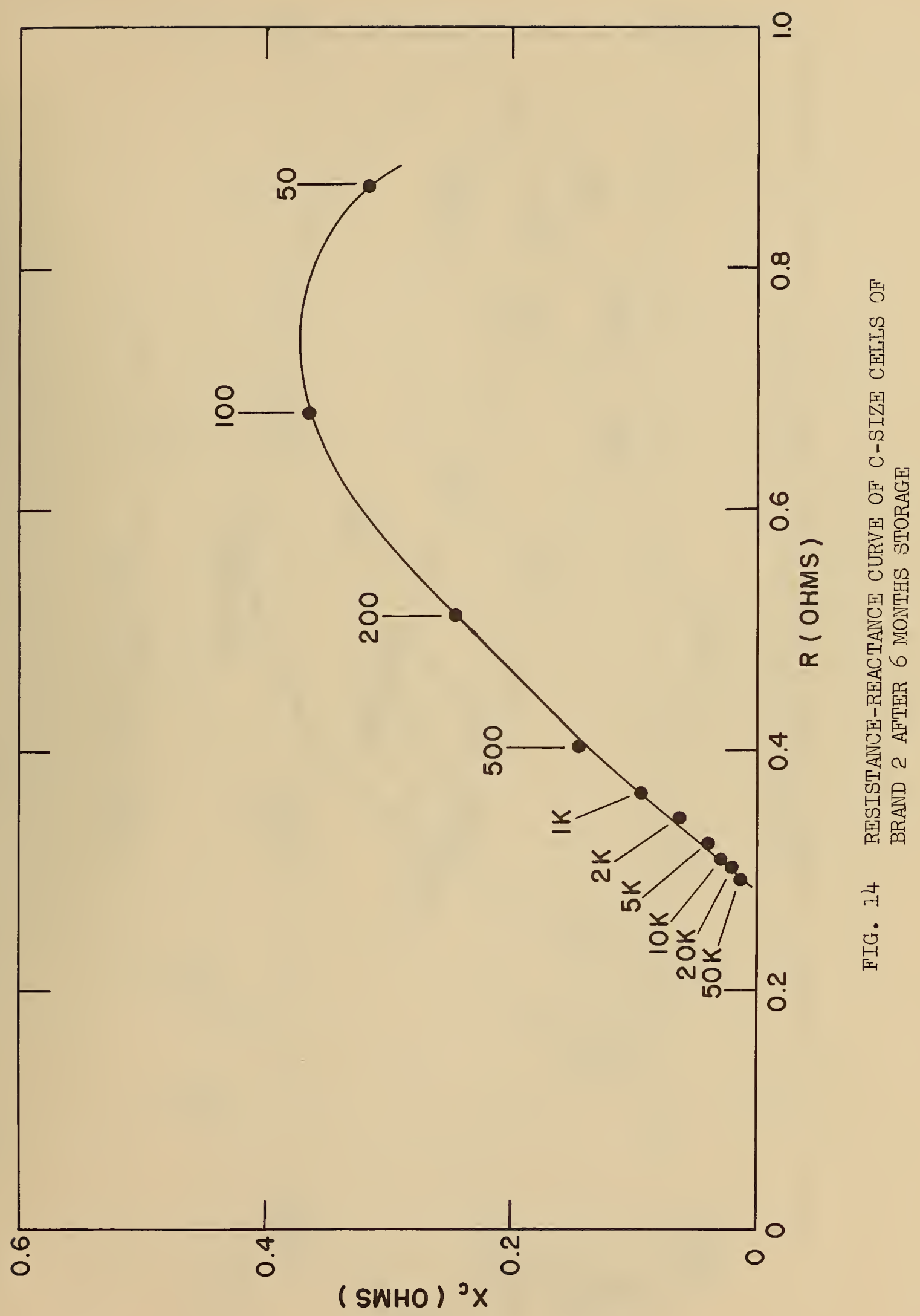




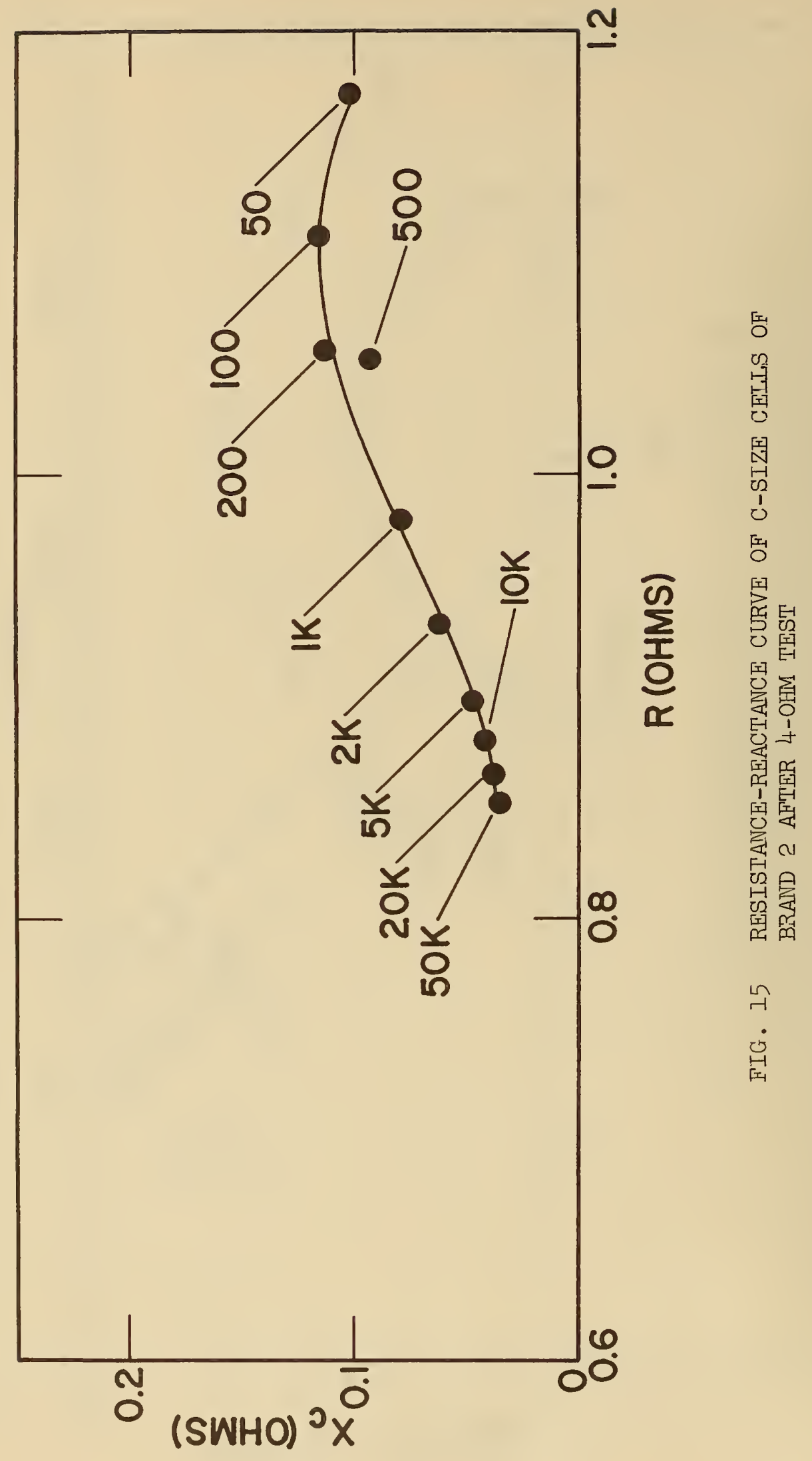




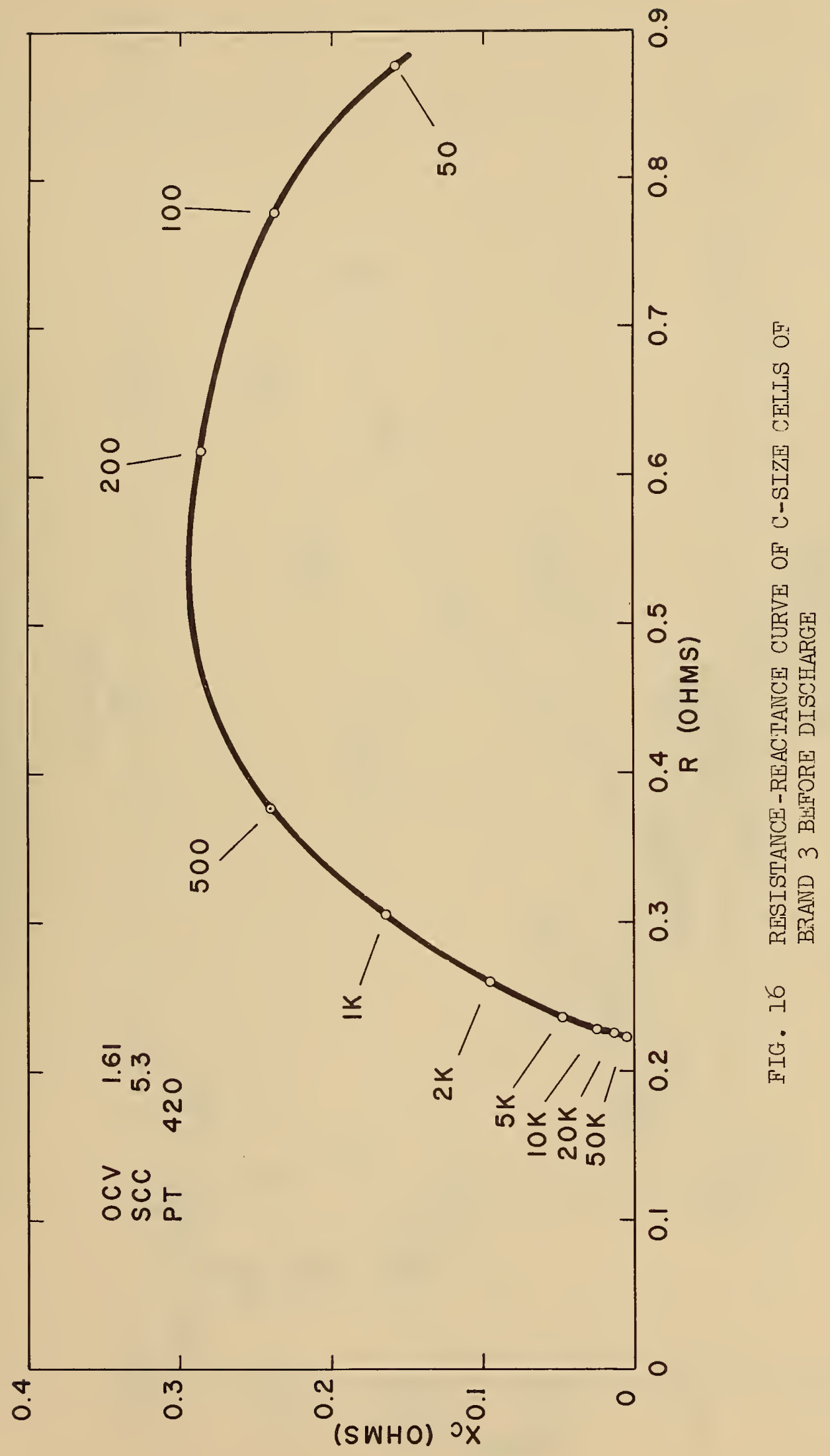




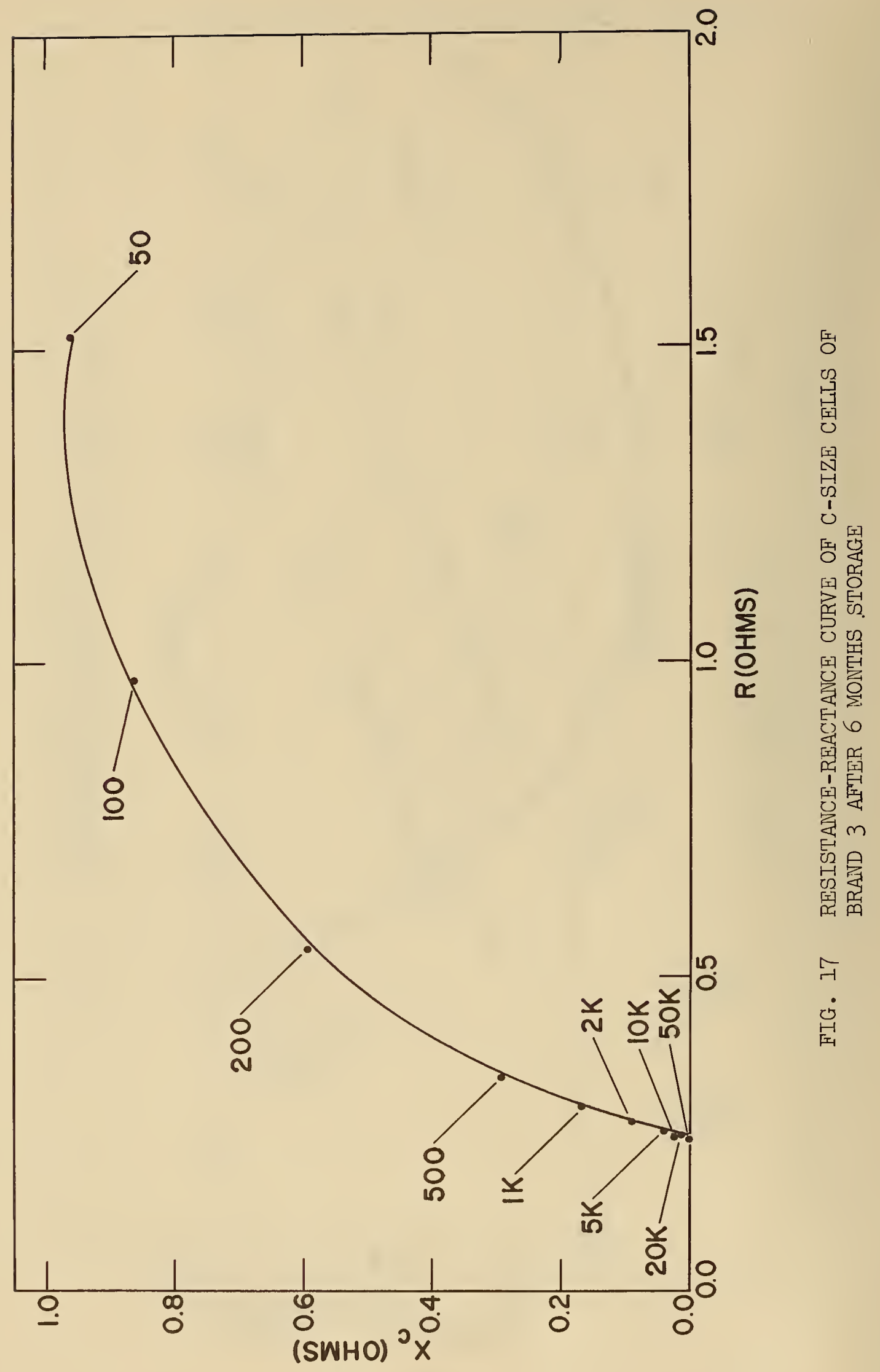




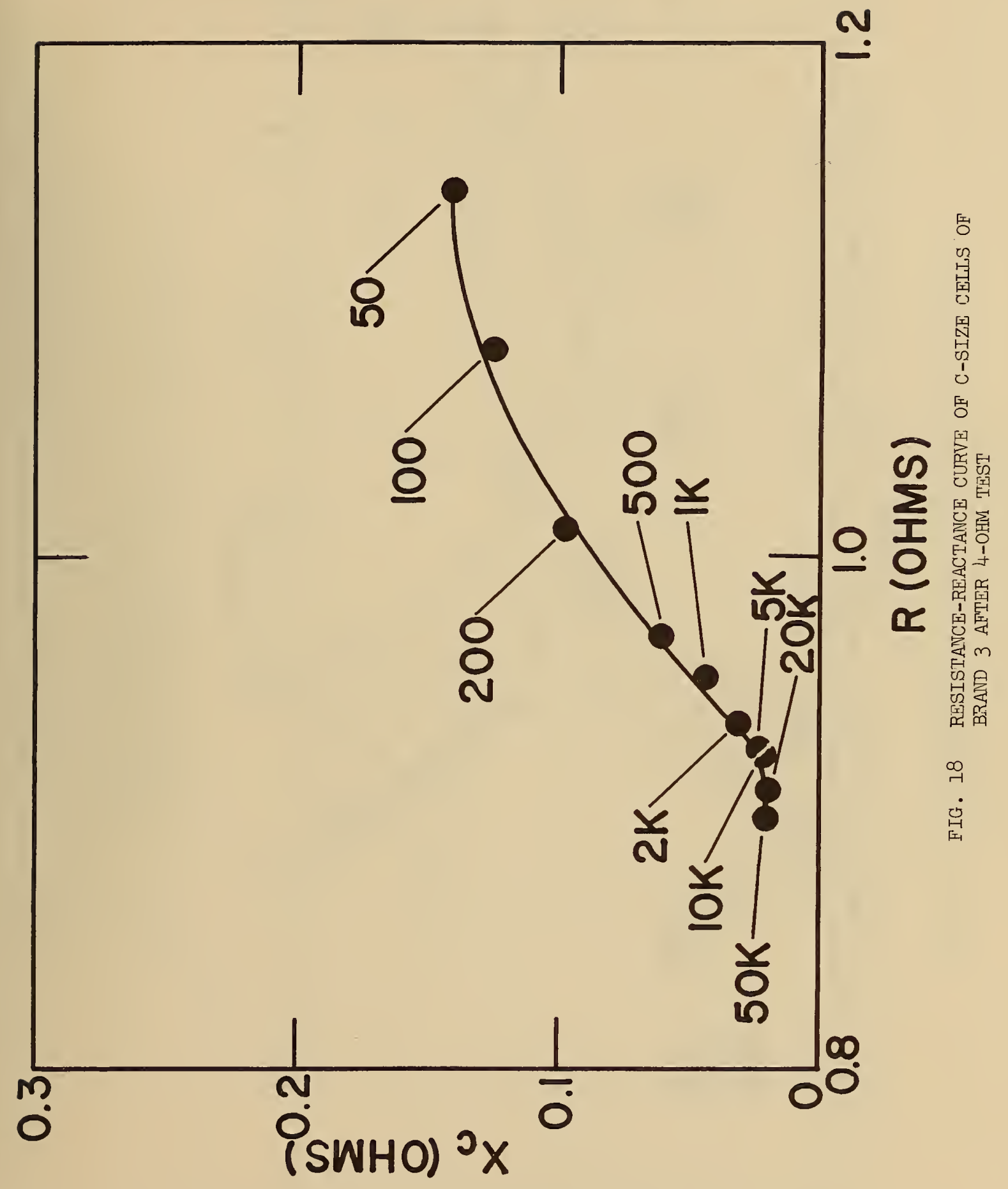




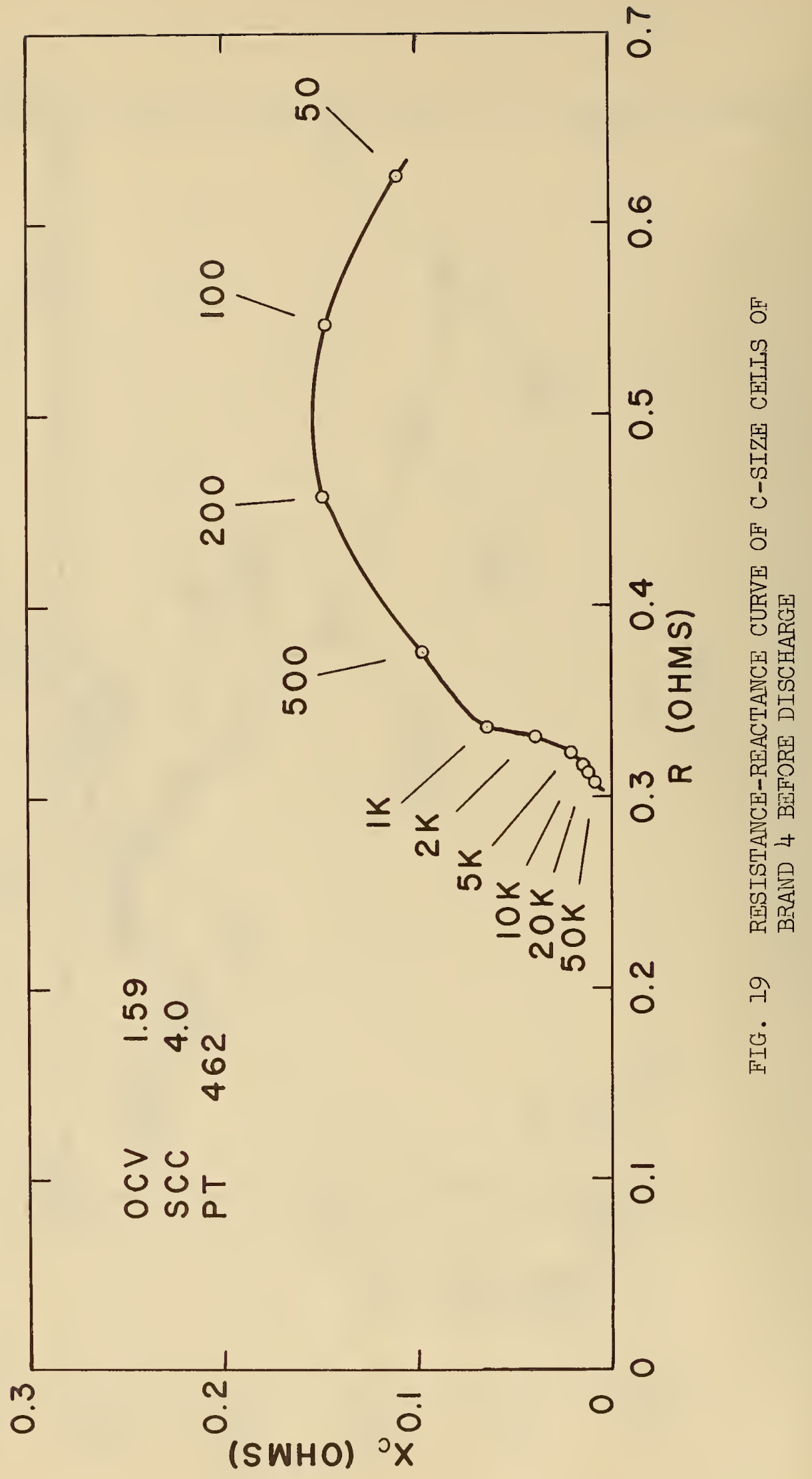




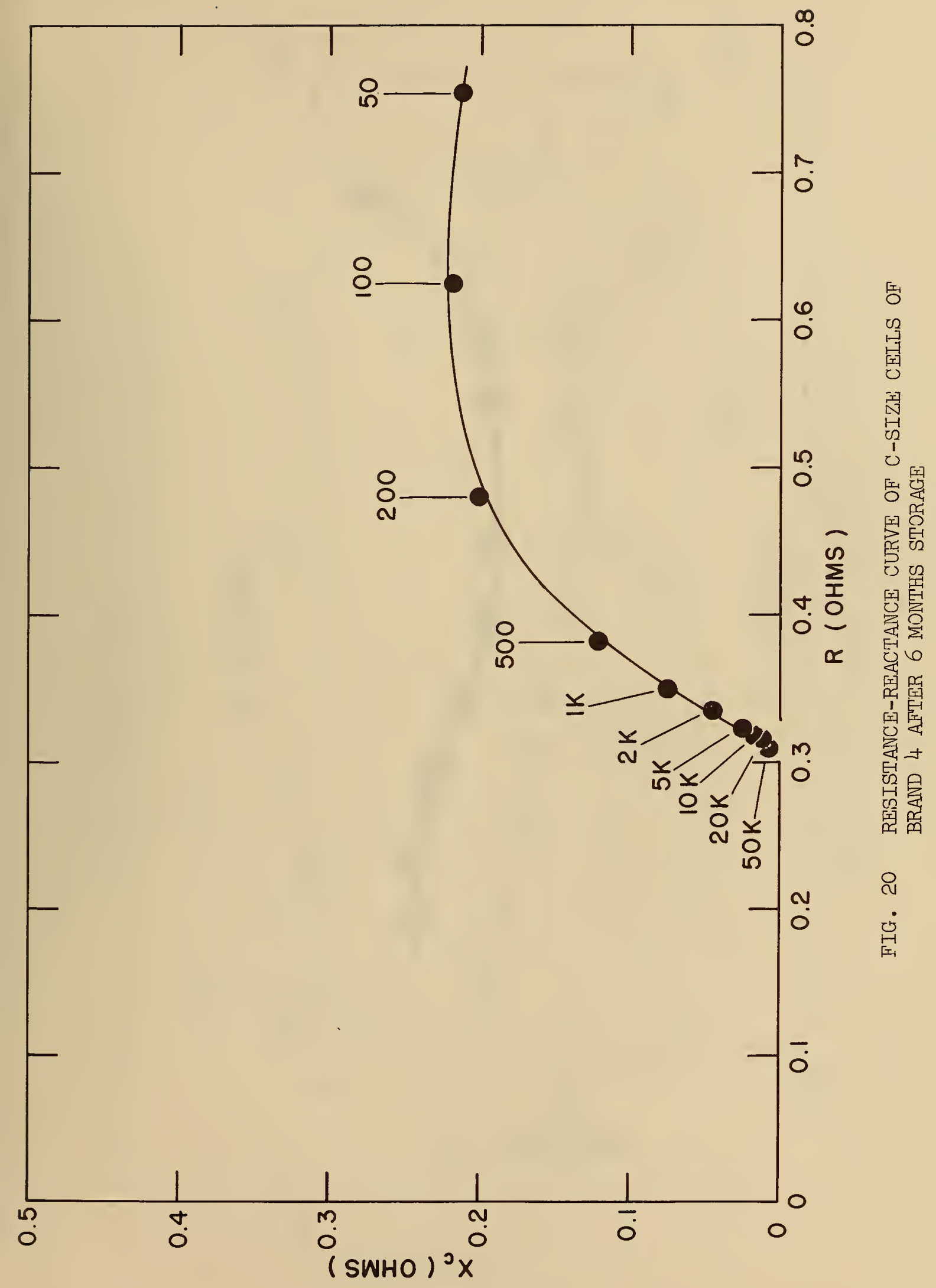




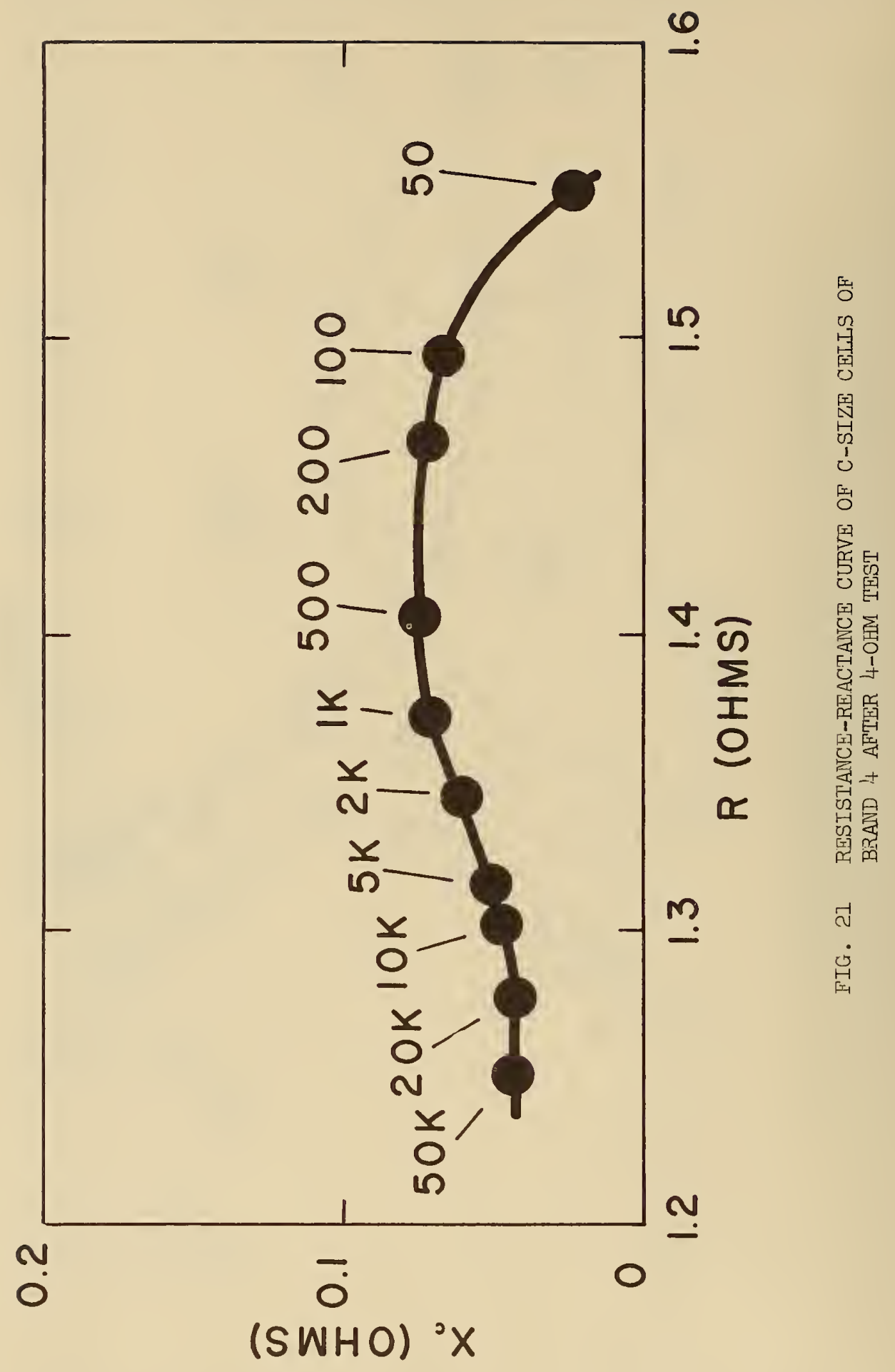




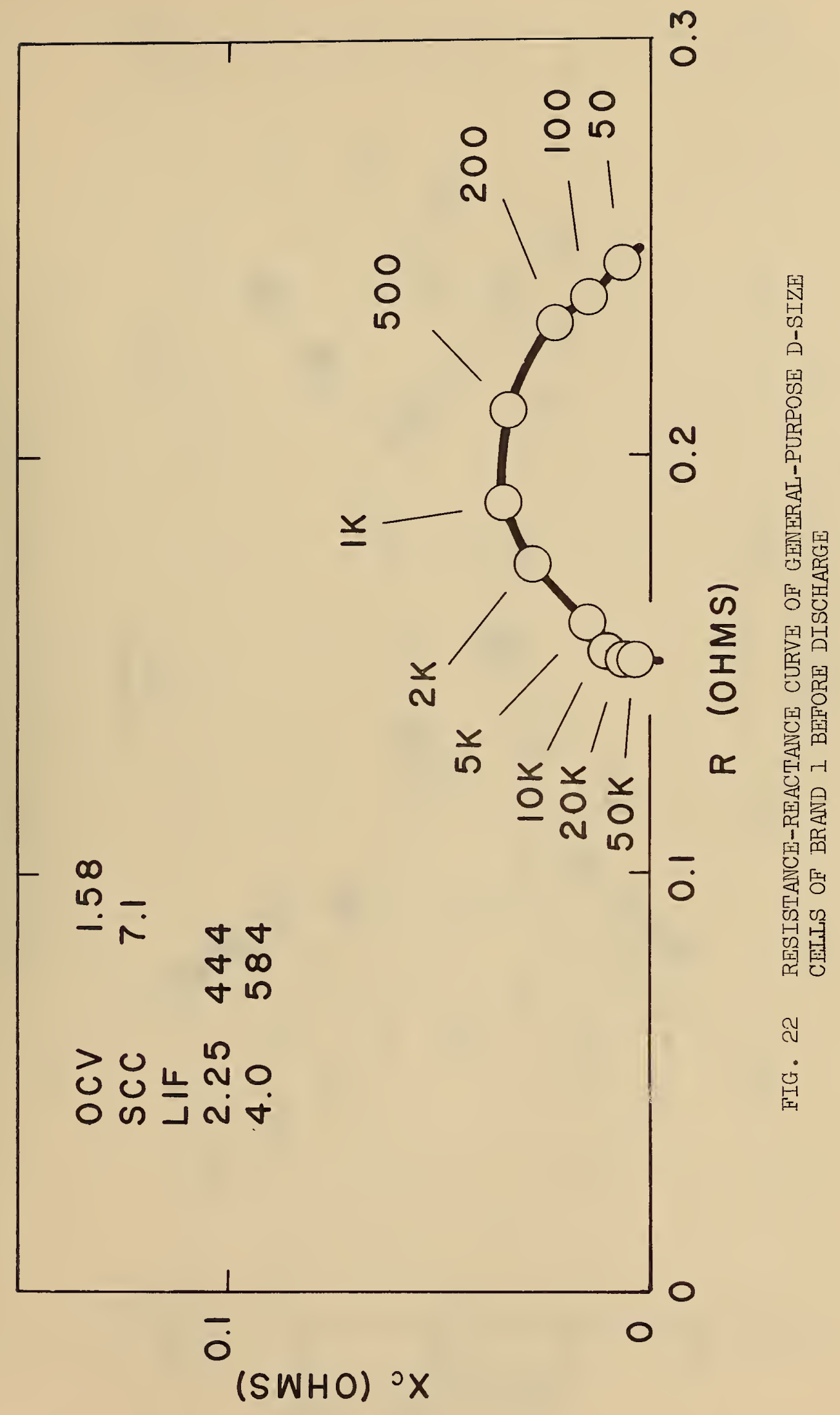




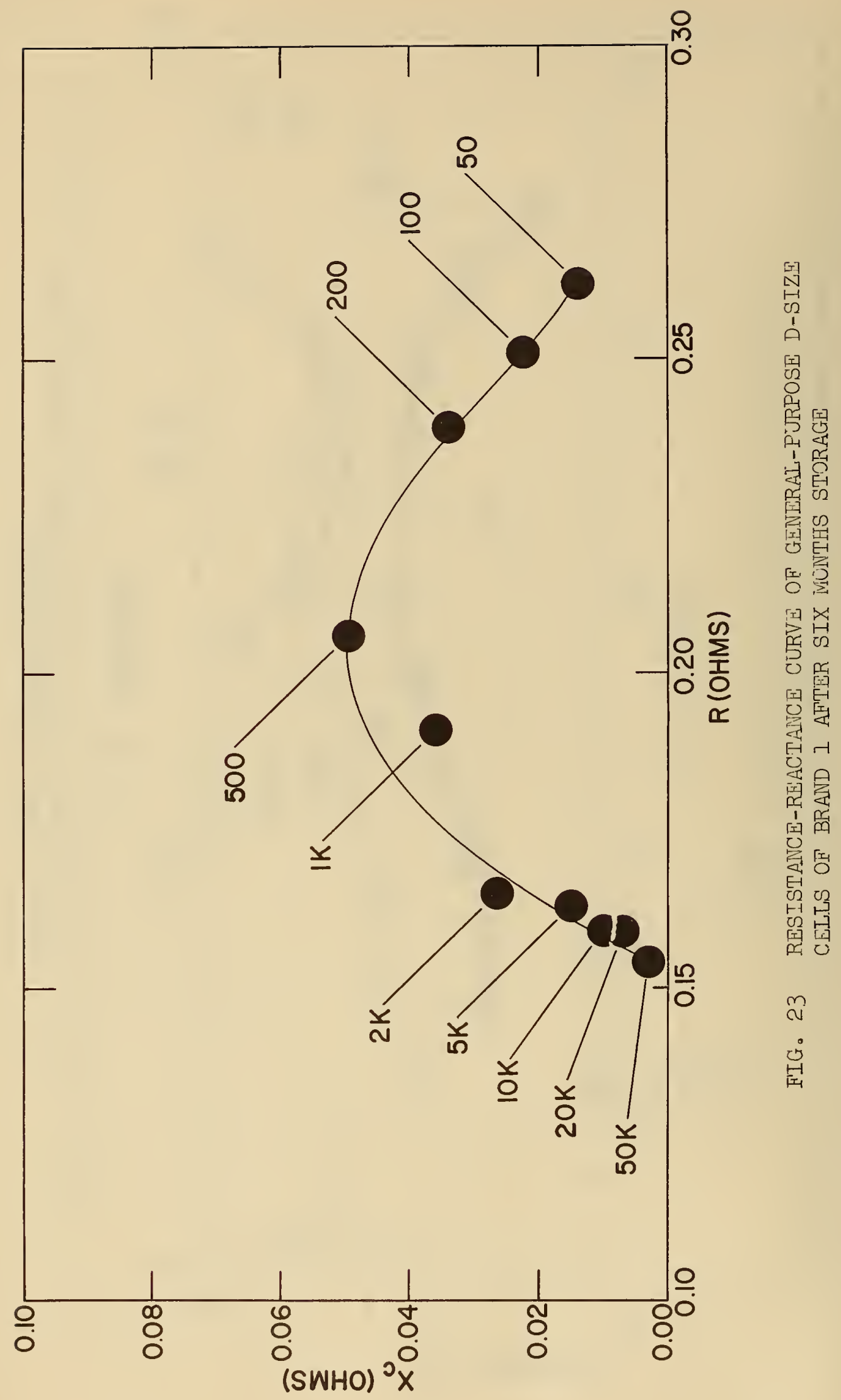




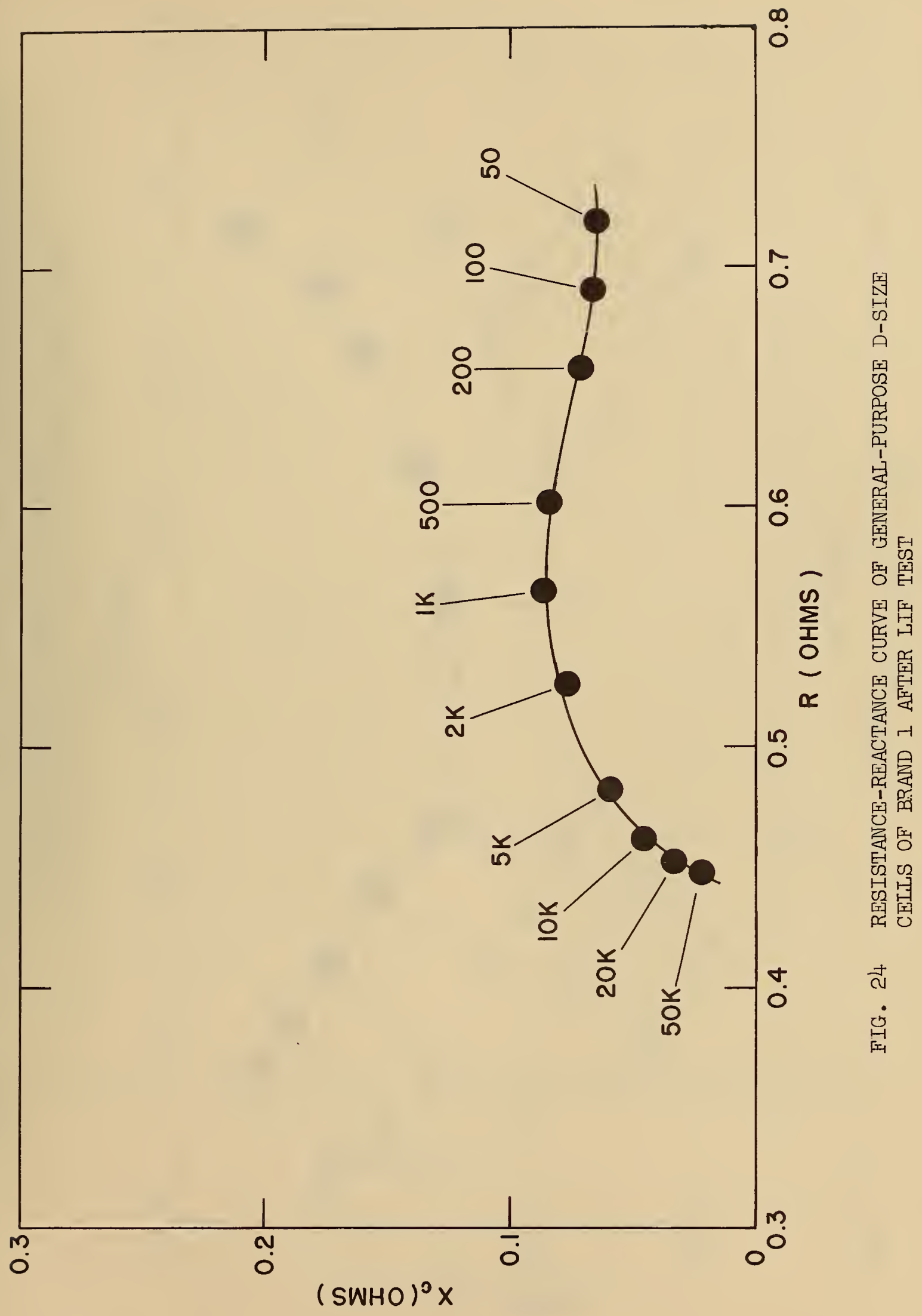




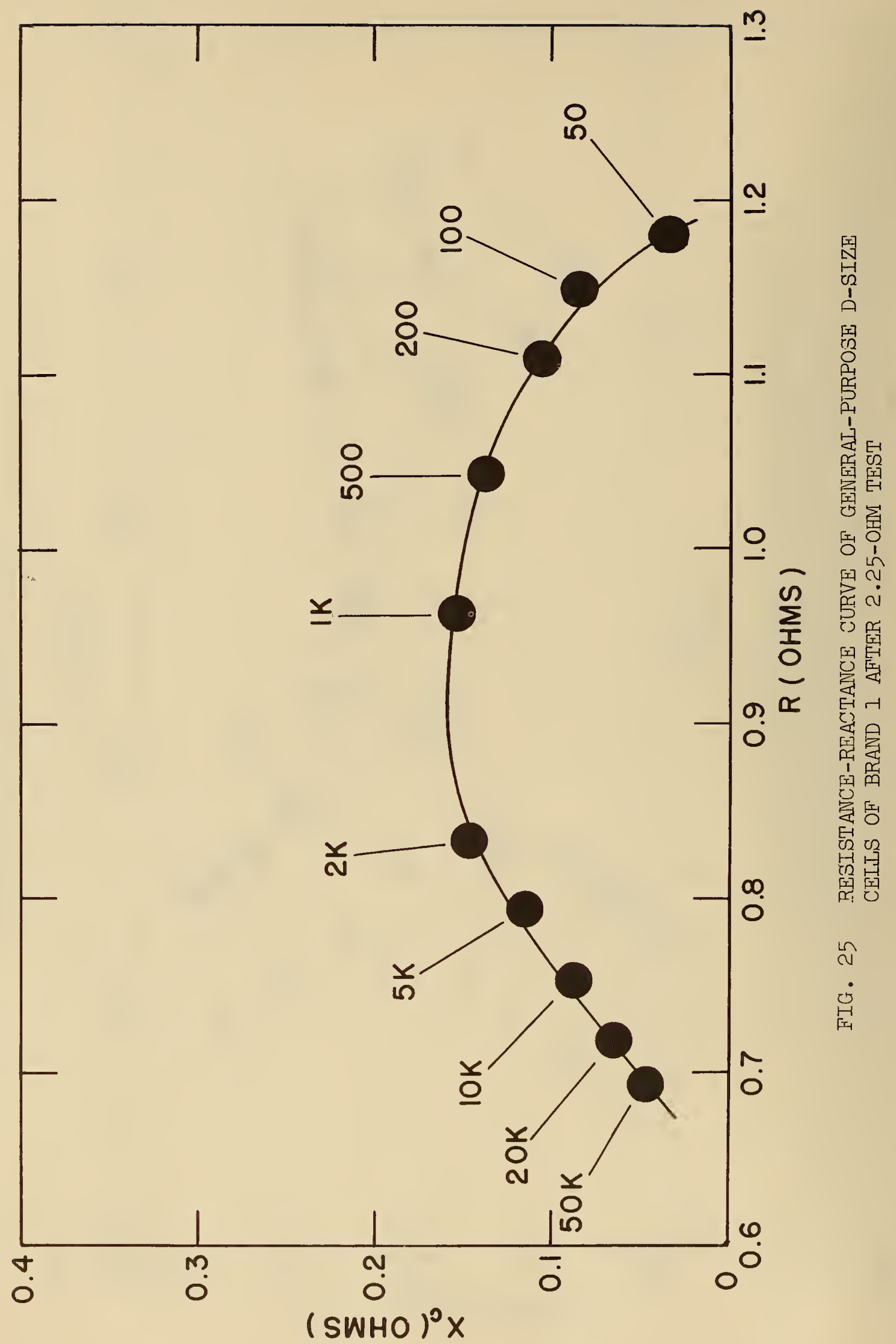




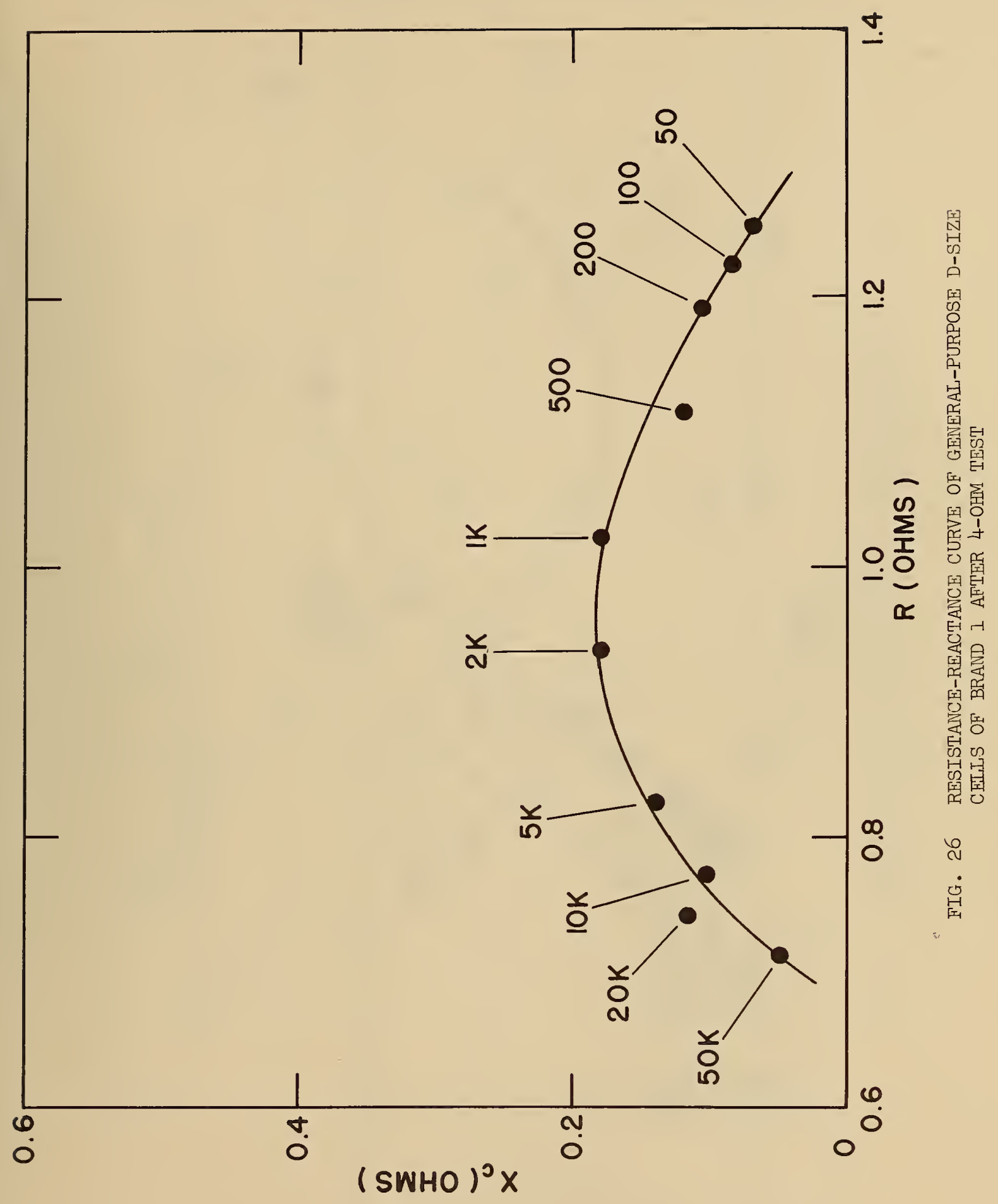




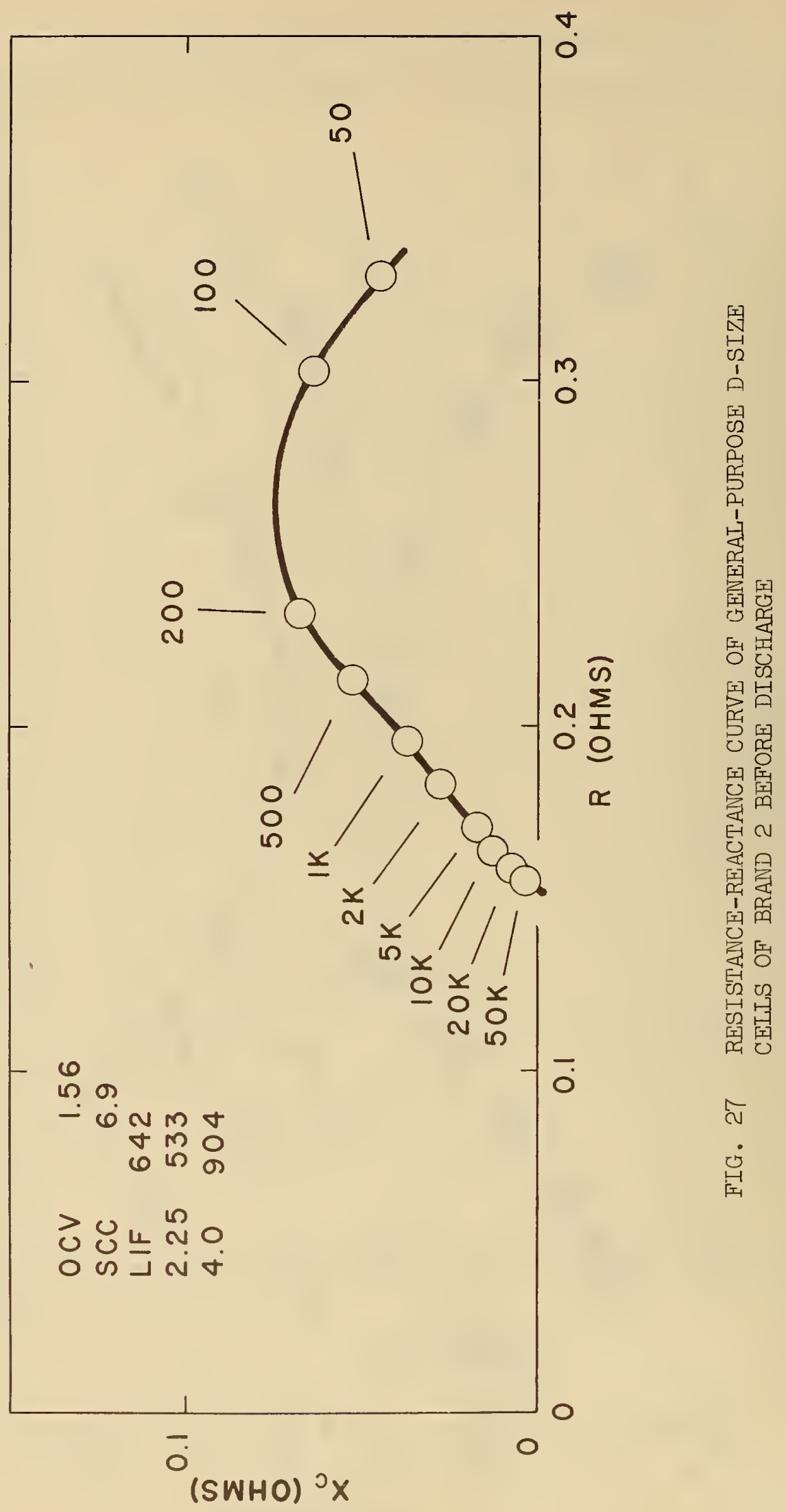




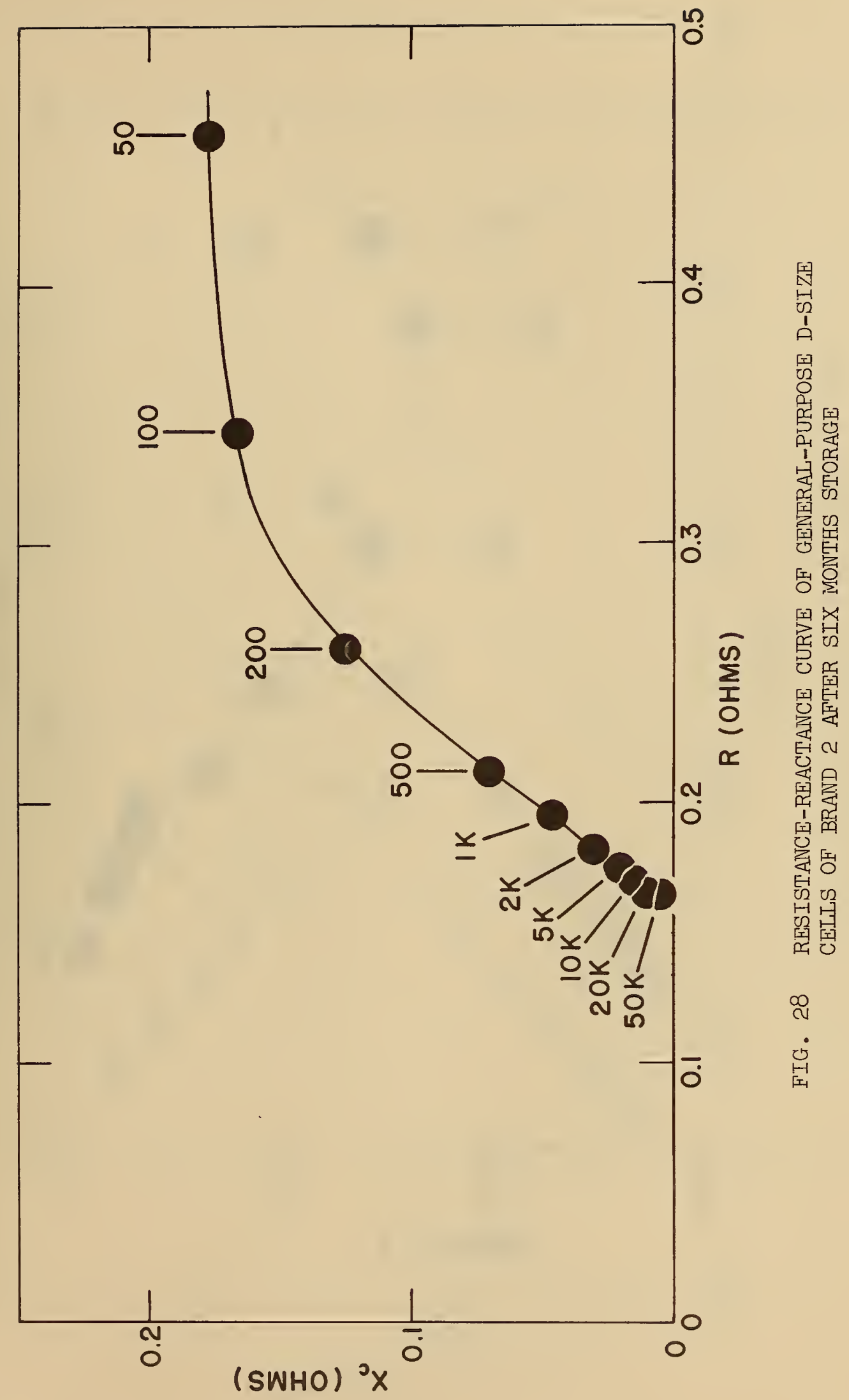




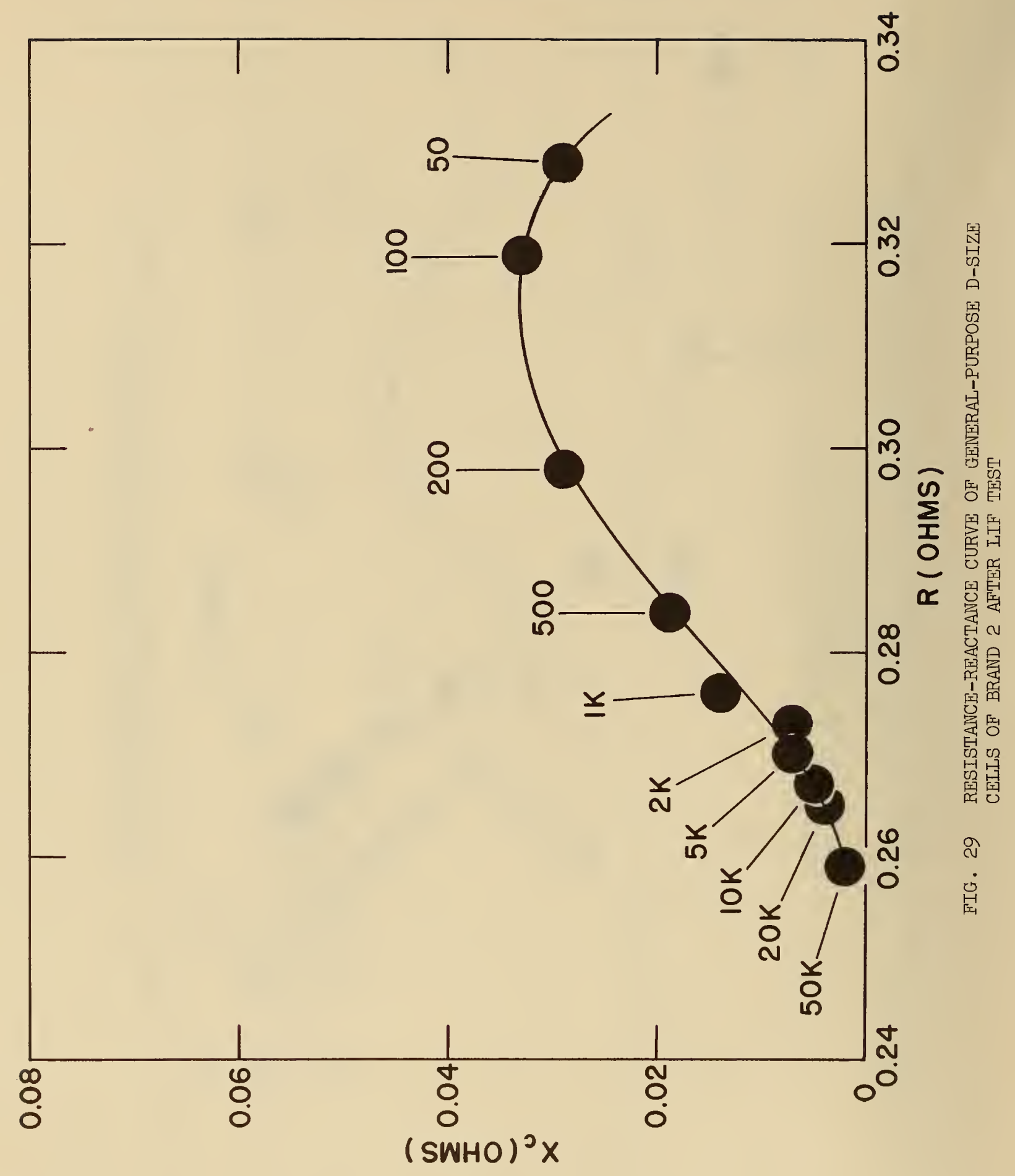




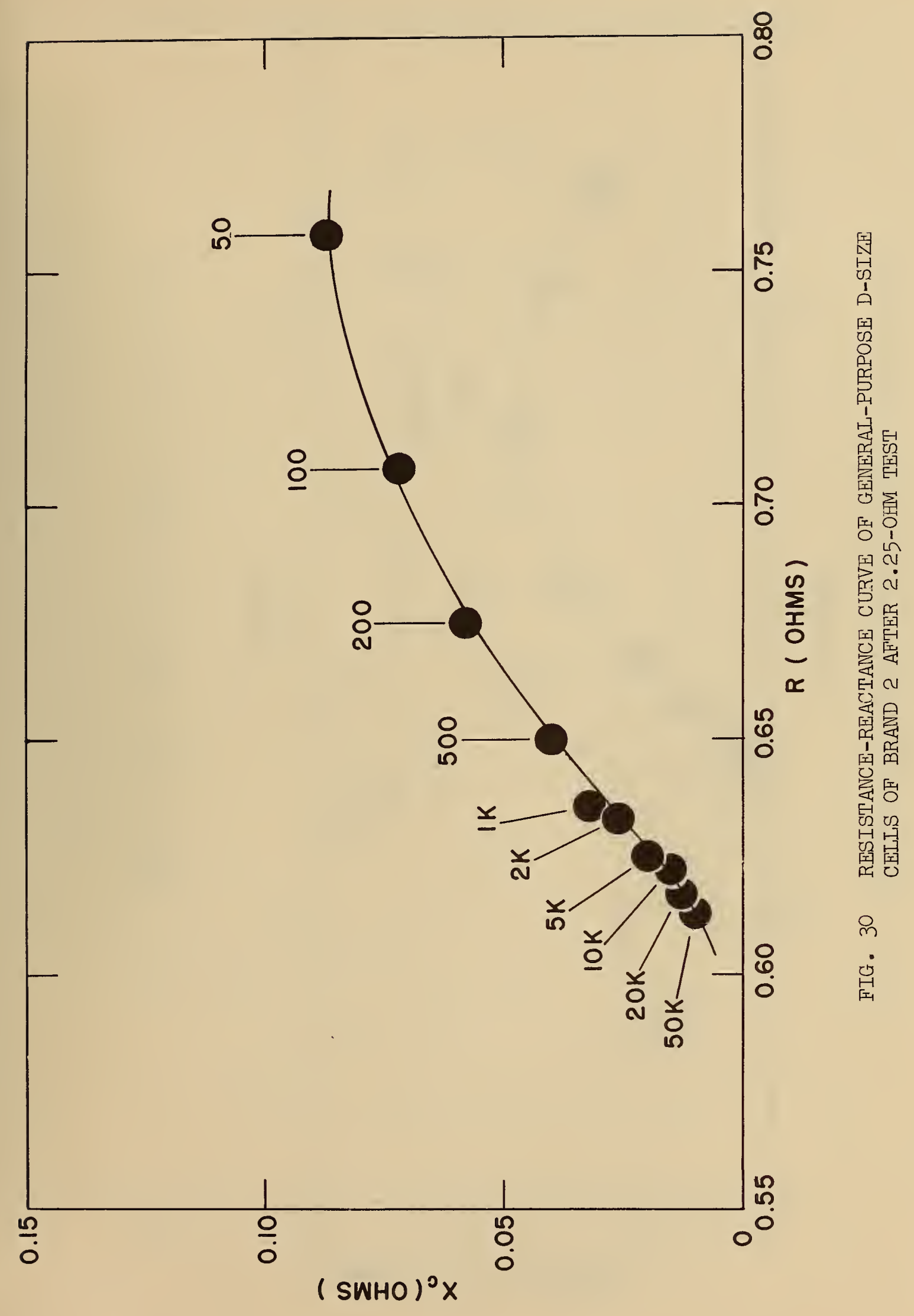




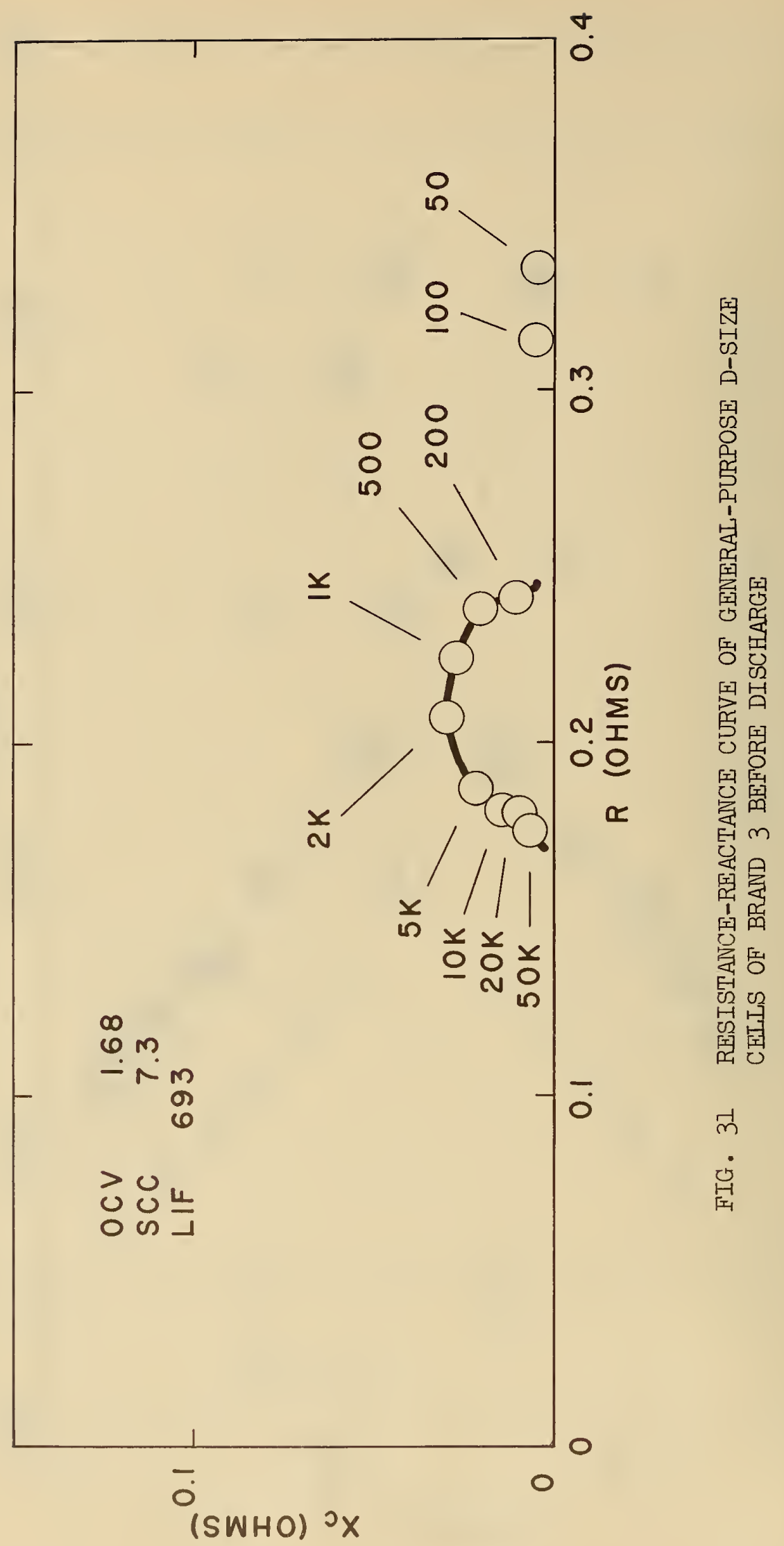




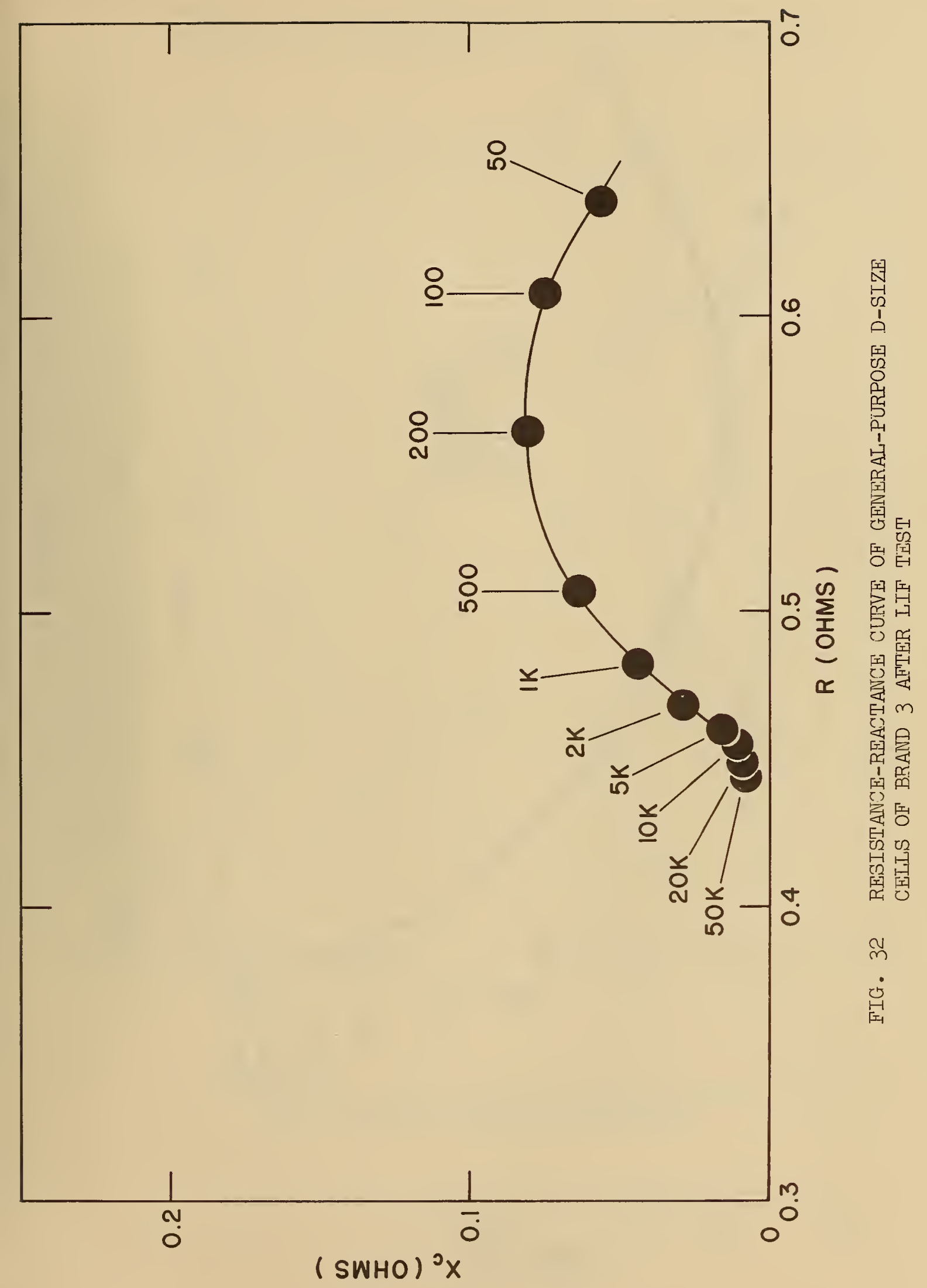




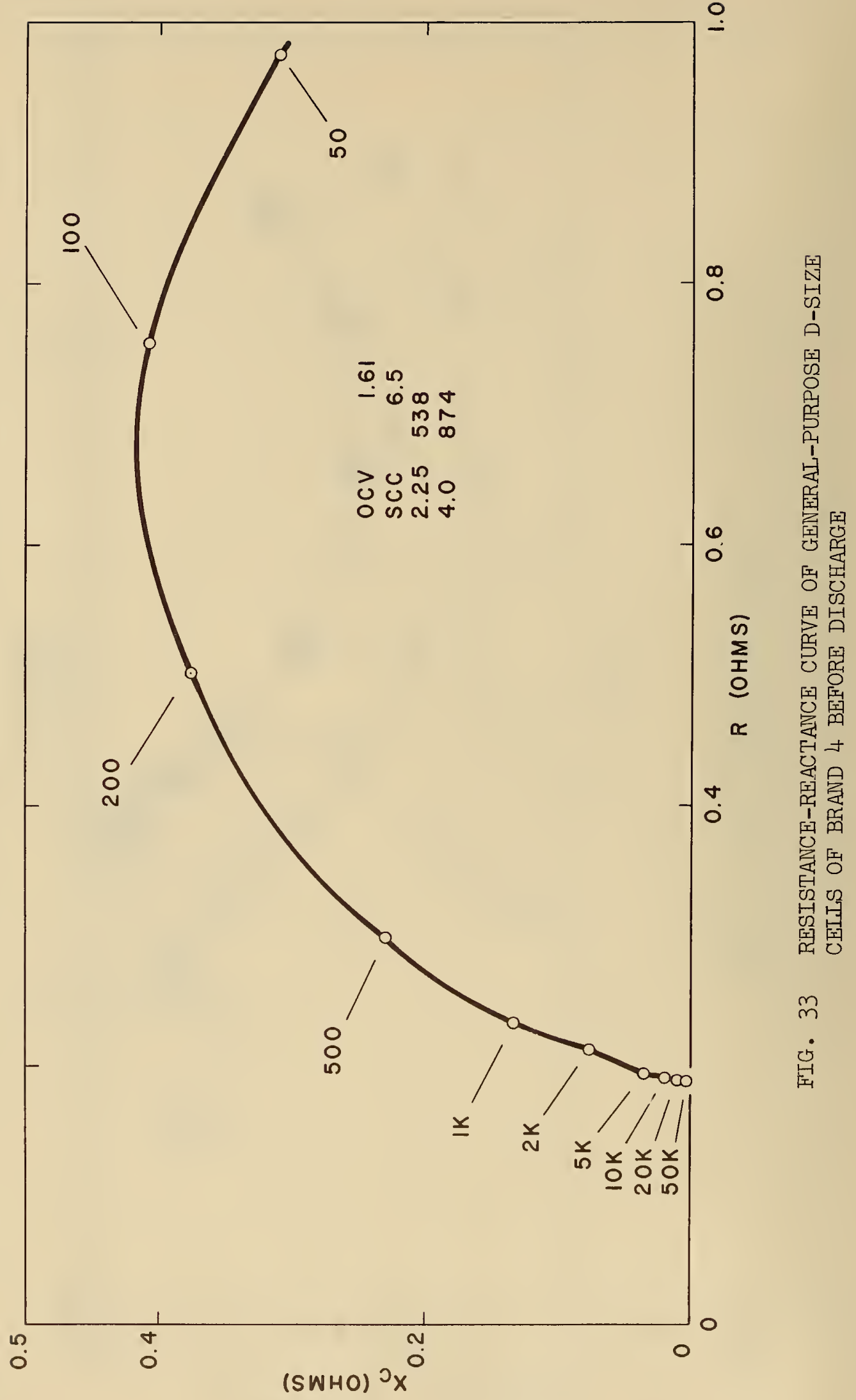




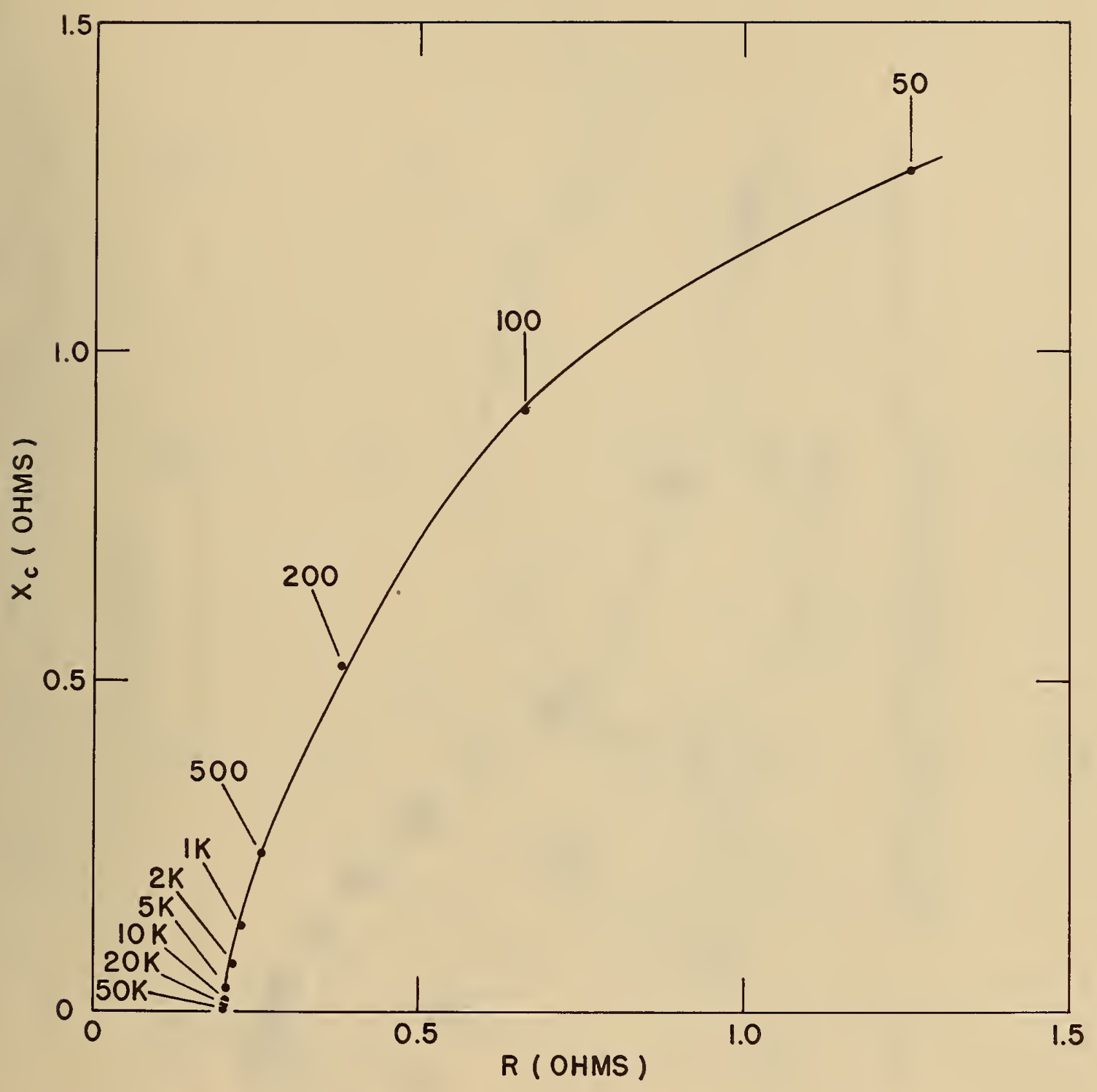

FIG. 34 RESISTANCE-REACTANCE CURVE OF GENERAL-PURPOSE D-SIZE CELIS OF BRAND 4 AF'TER SIX MONTHS STORAGE 


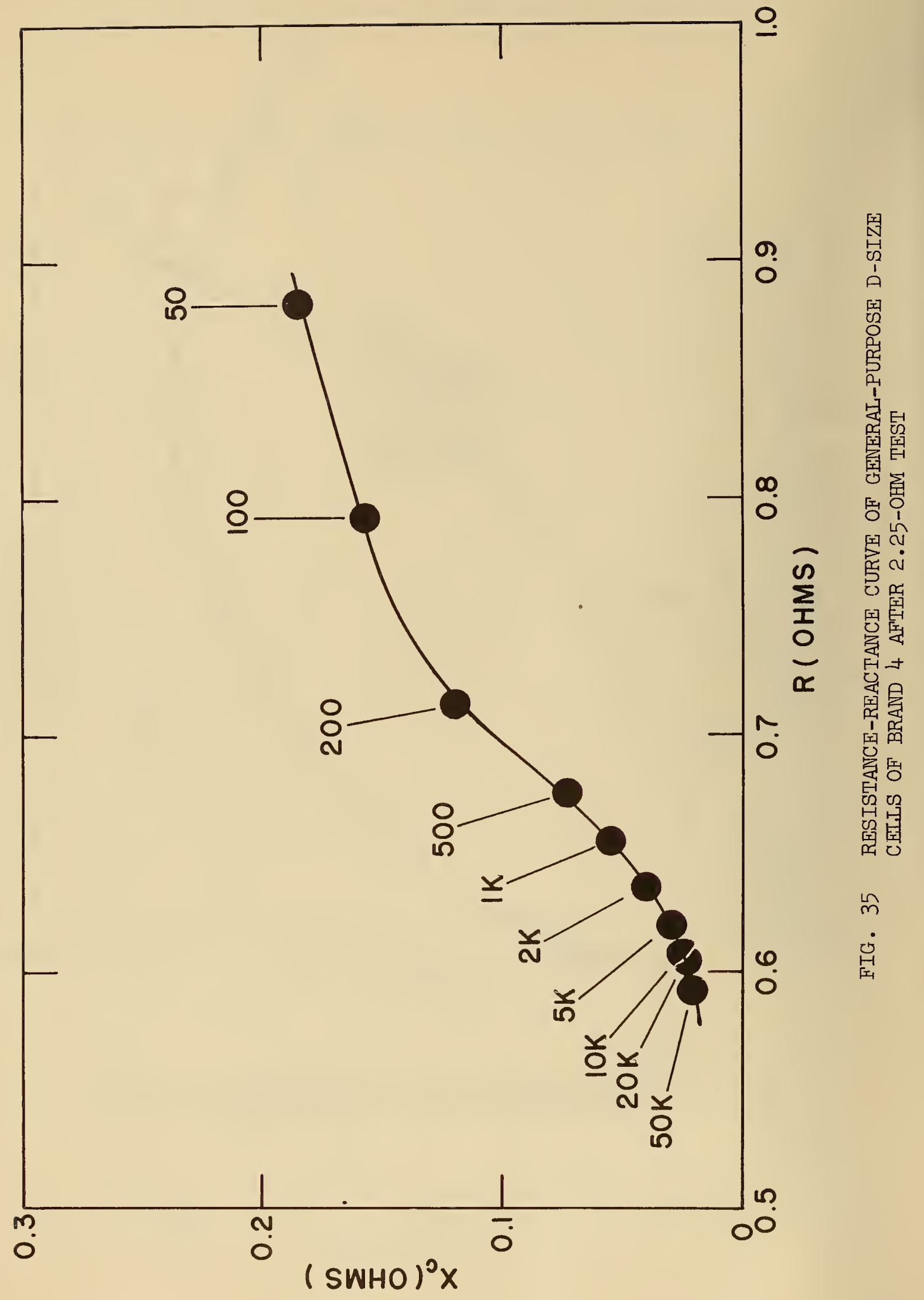




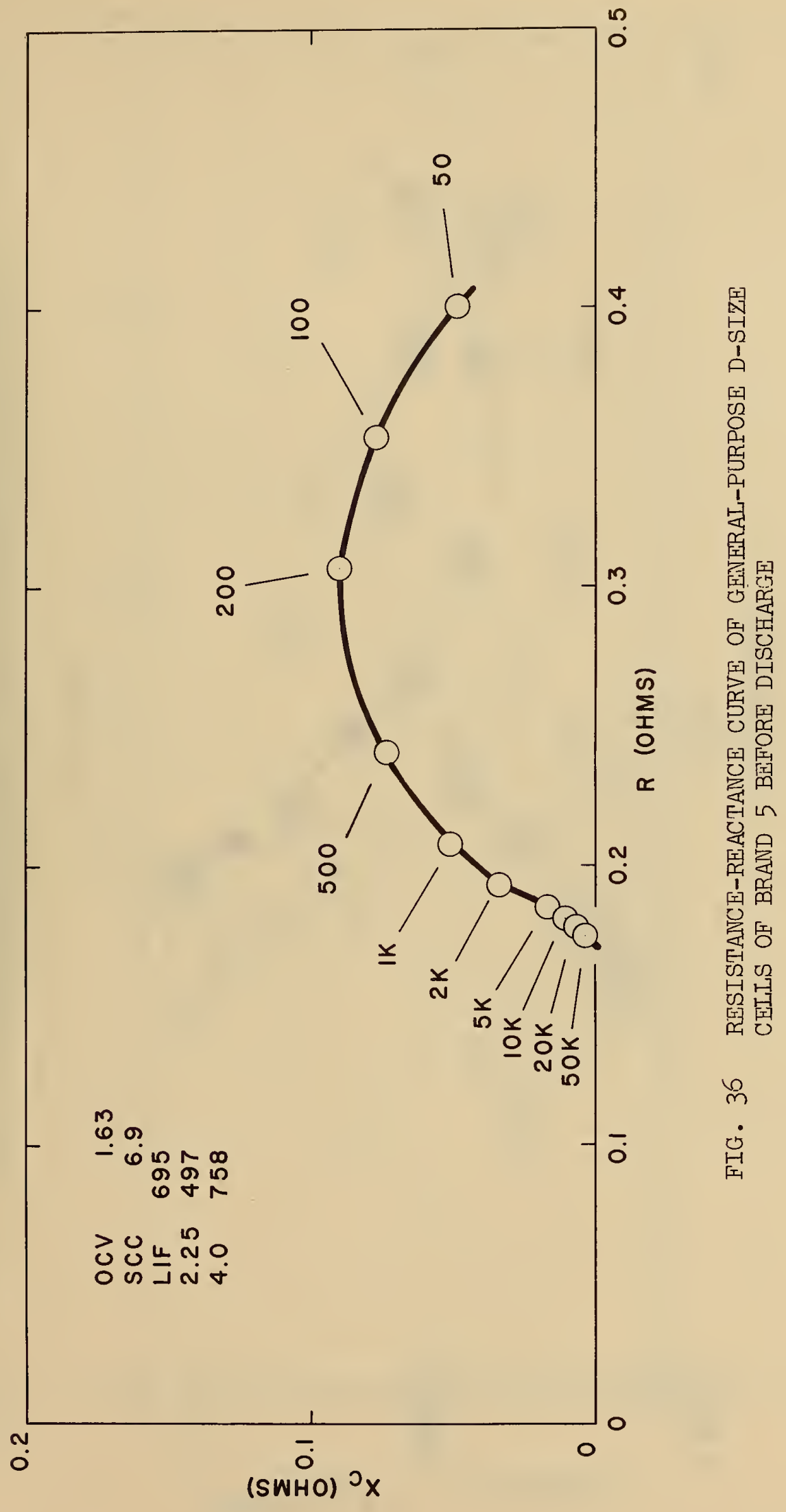




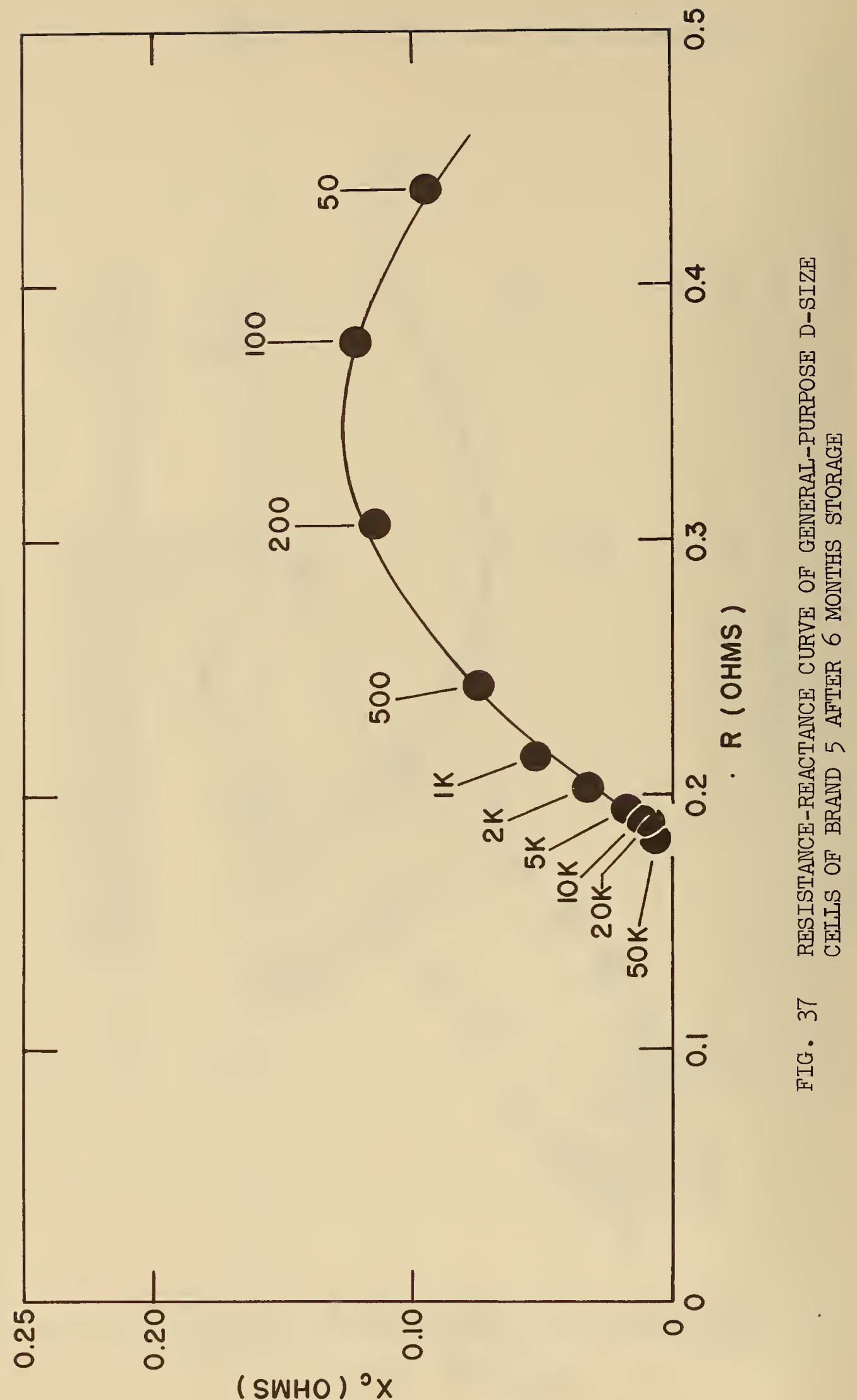




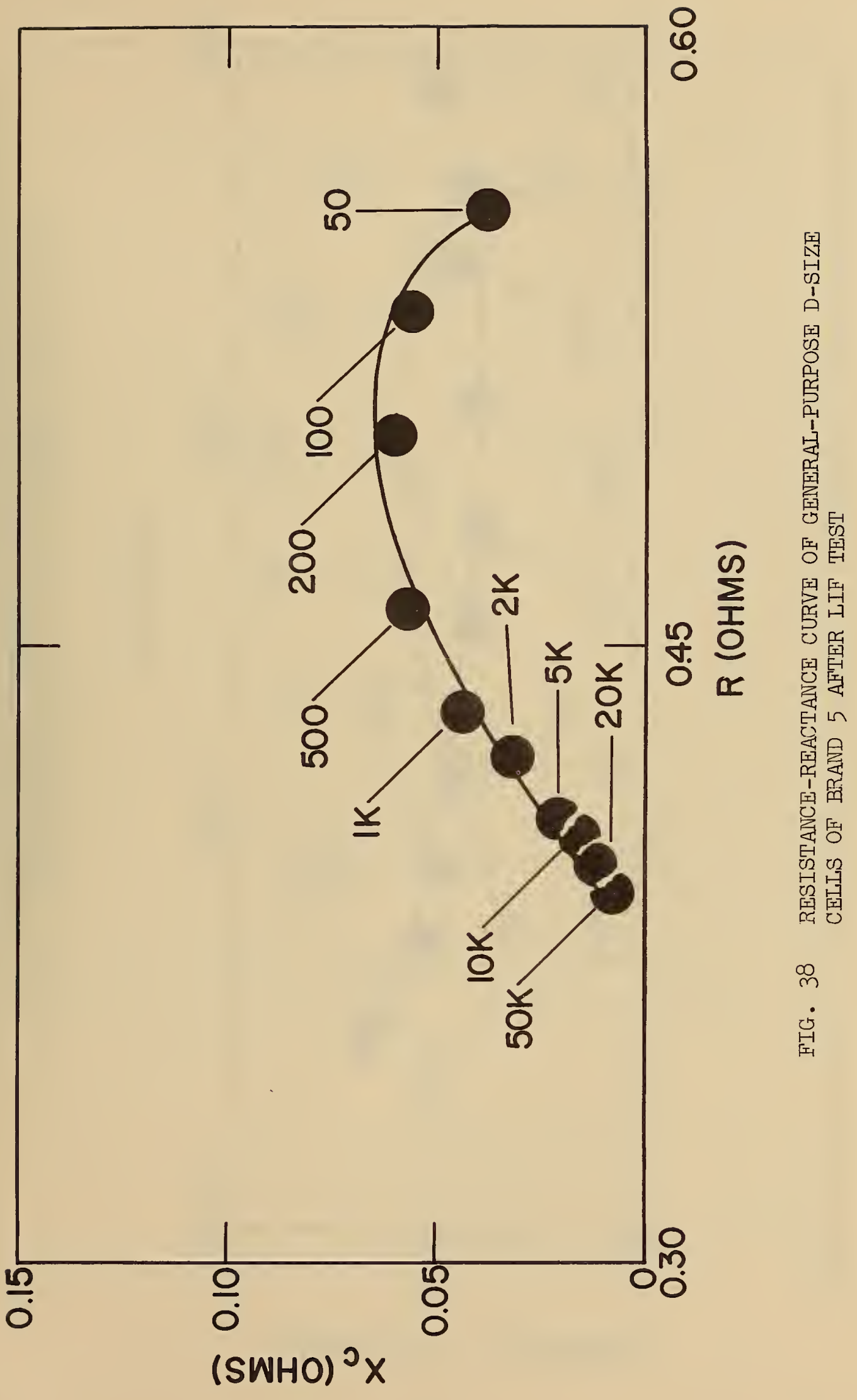




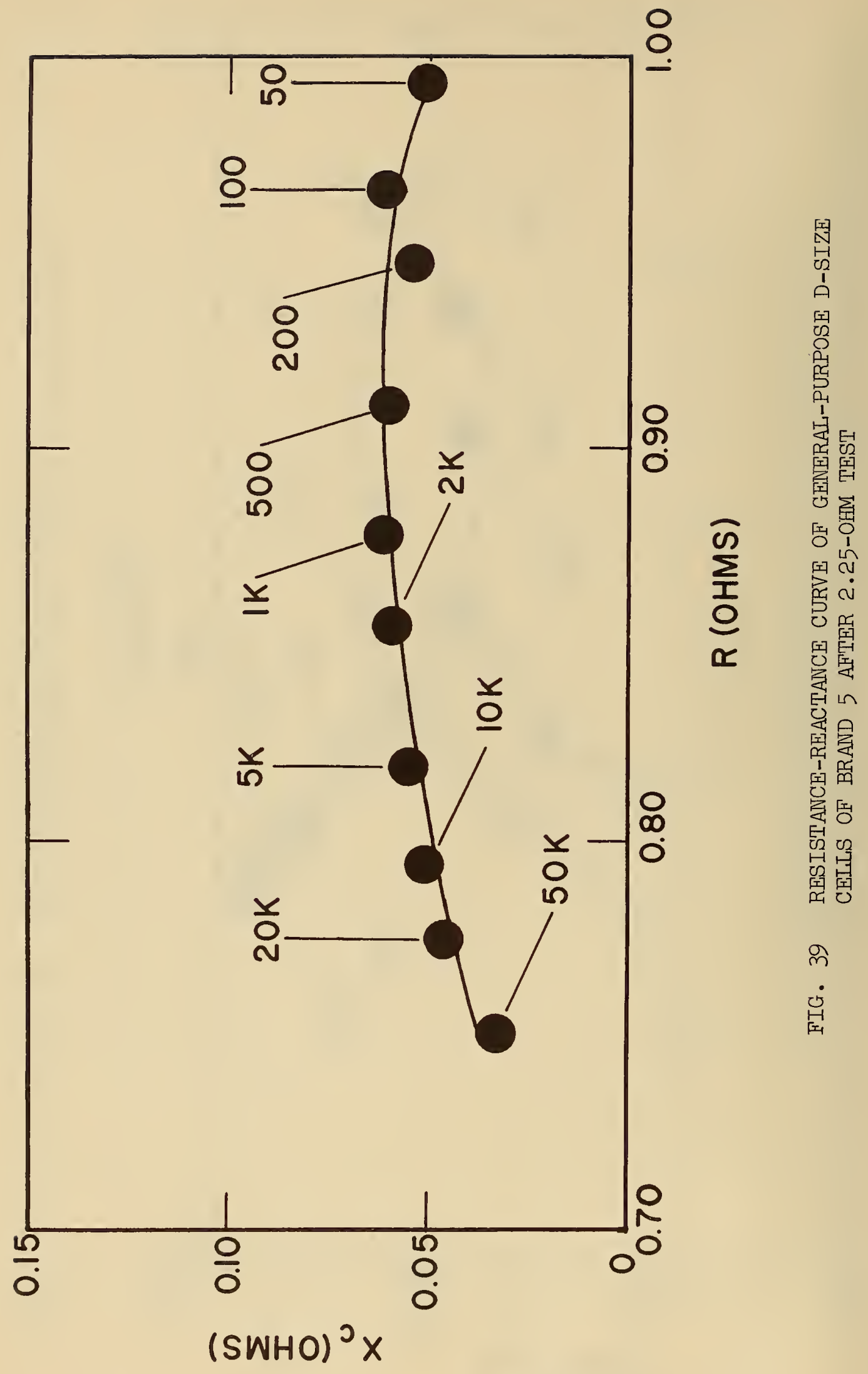




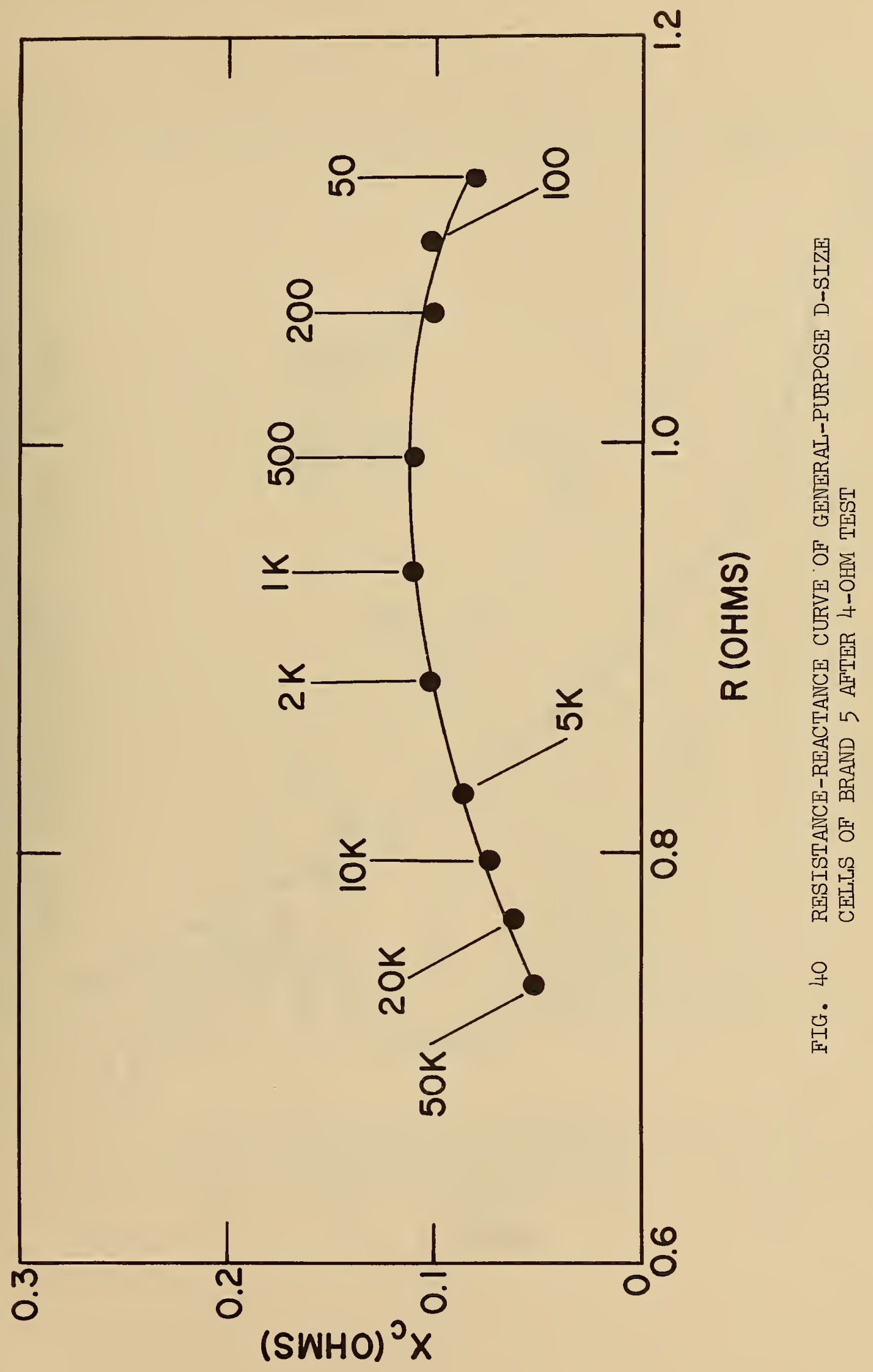




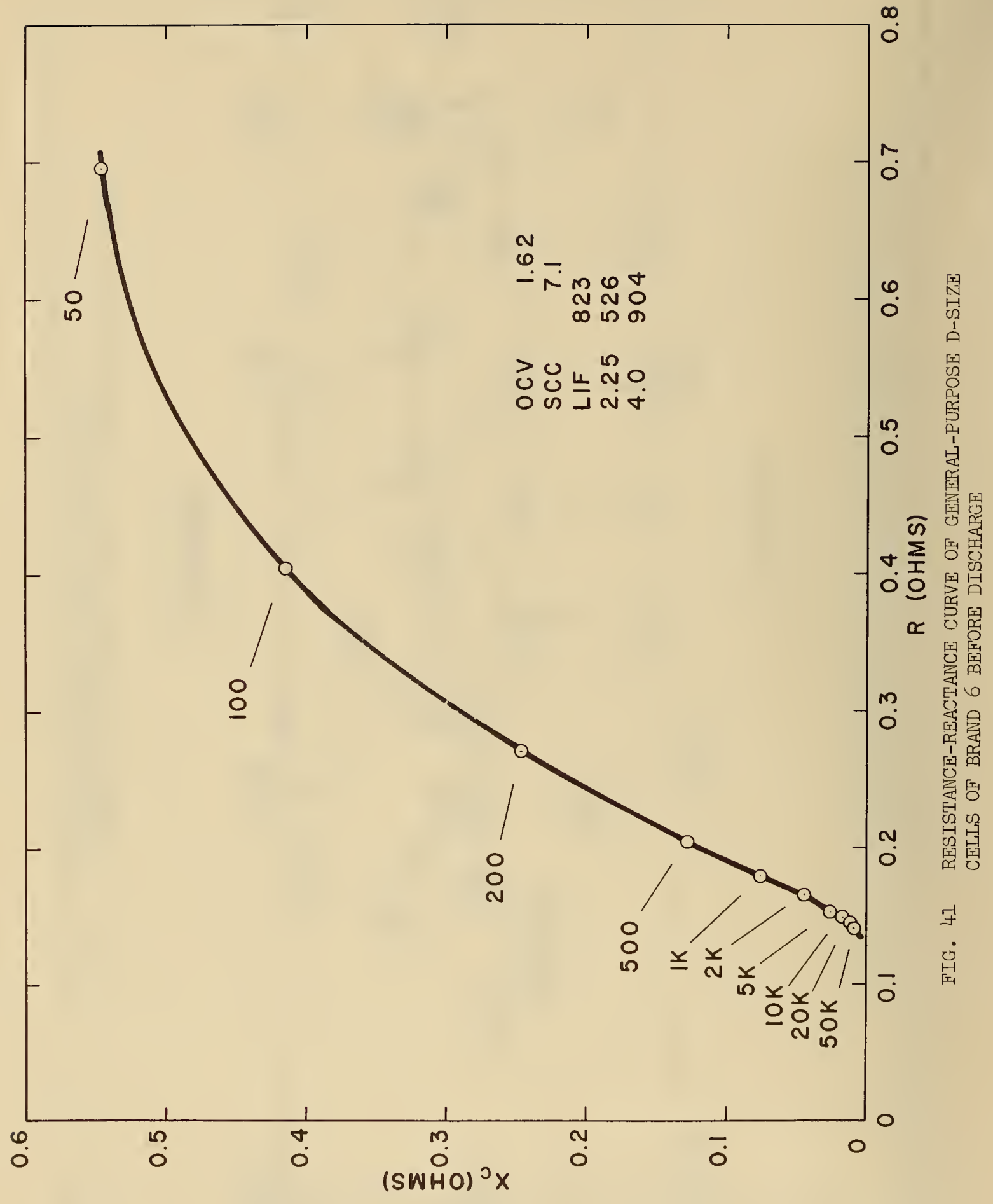




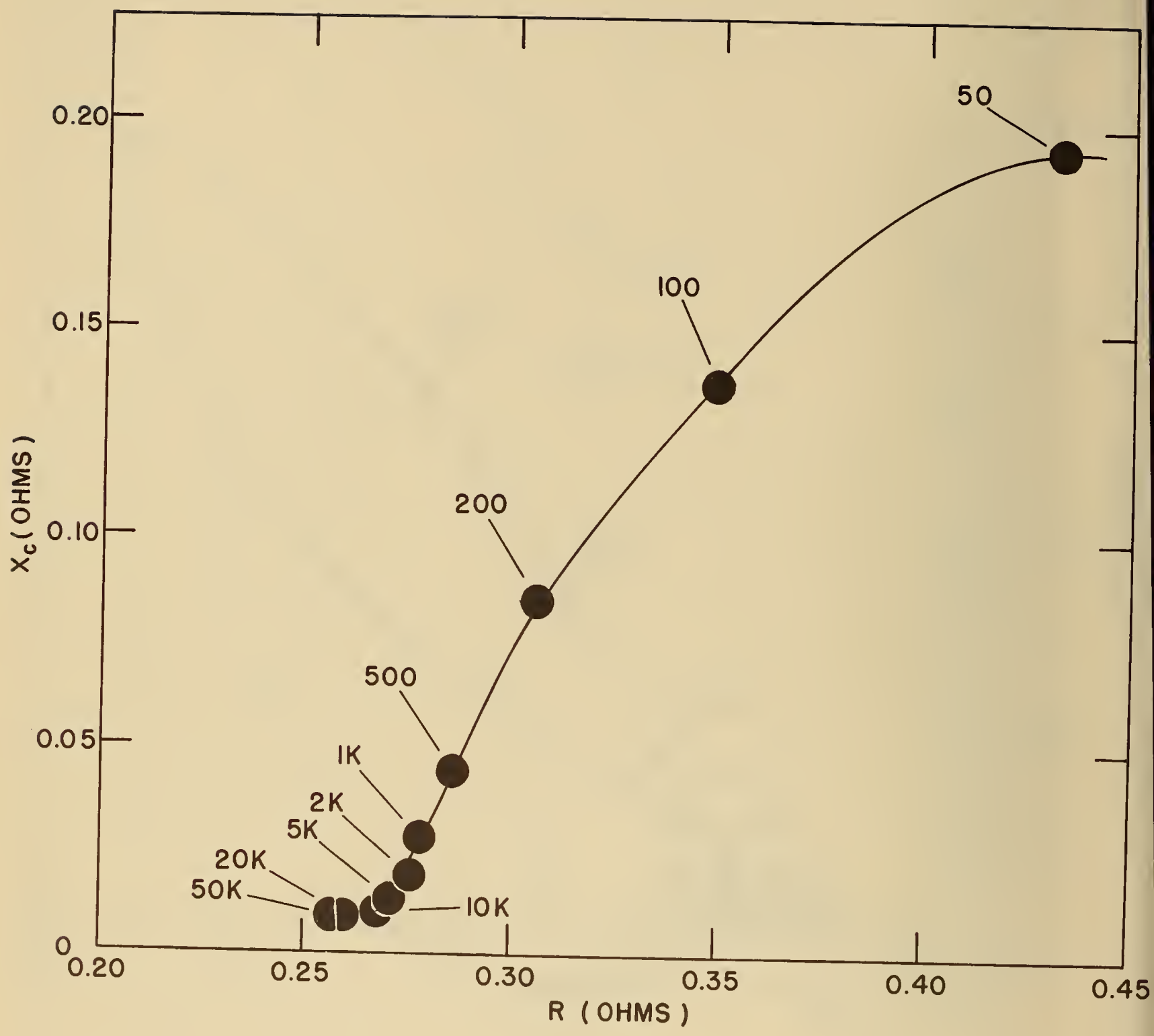

FIG. 43 RESISTANCE-REACTANCE CURVE OF GENERAL-PURPOSE D-SIZE CELIS OF BRAND 5 AFTER LIF TEST 


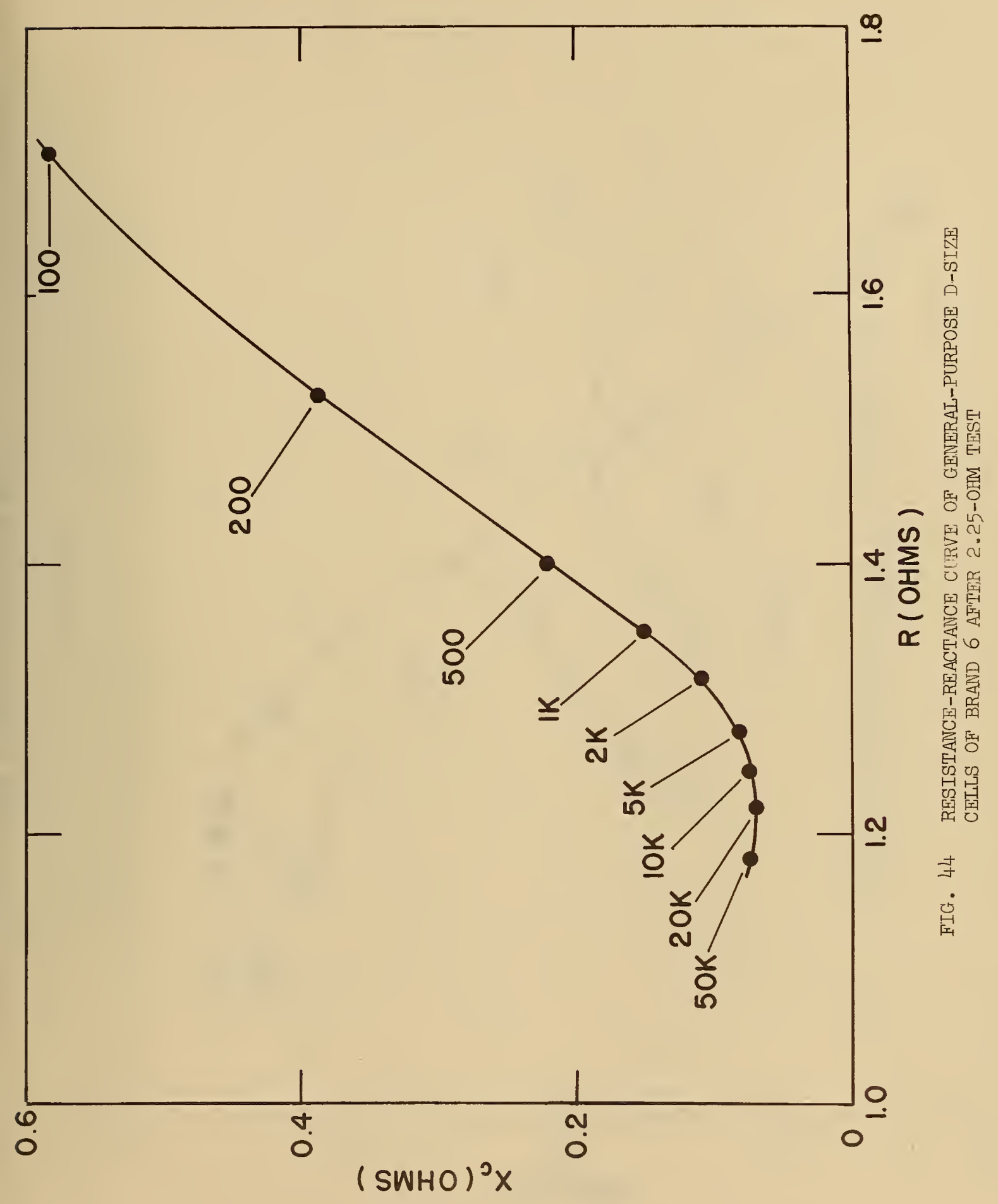




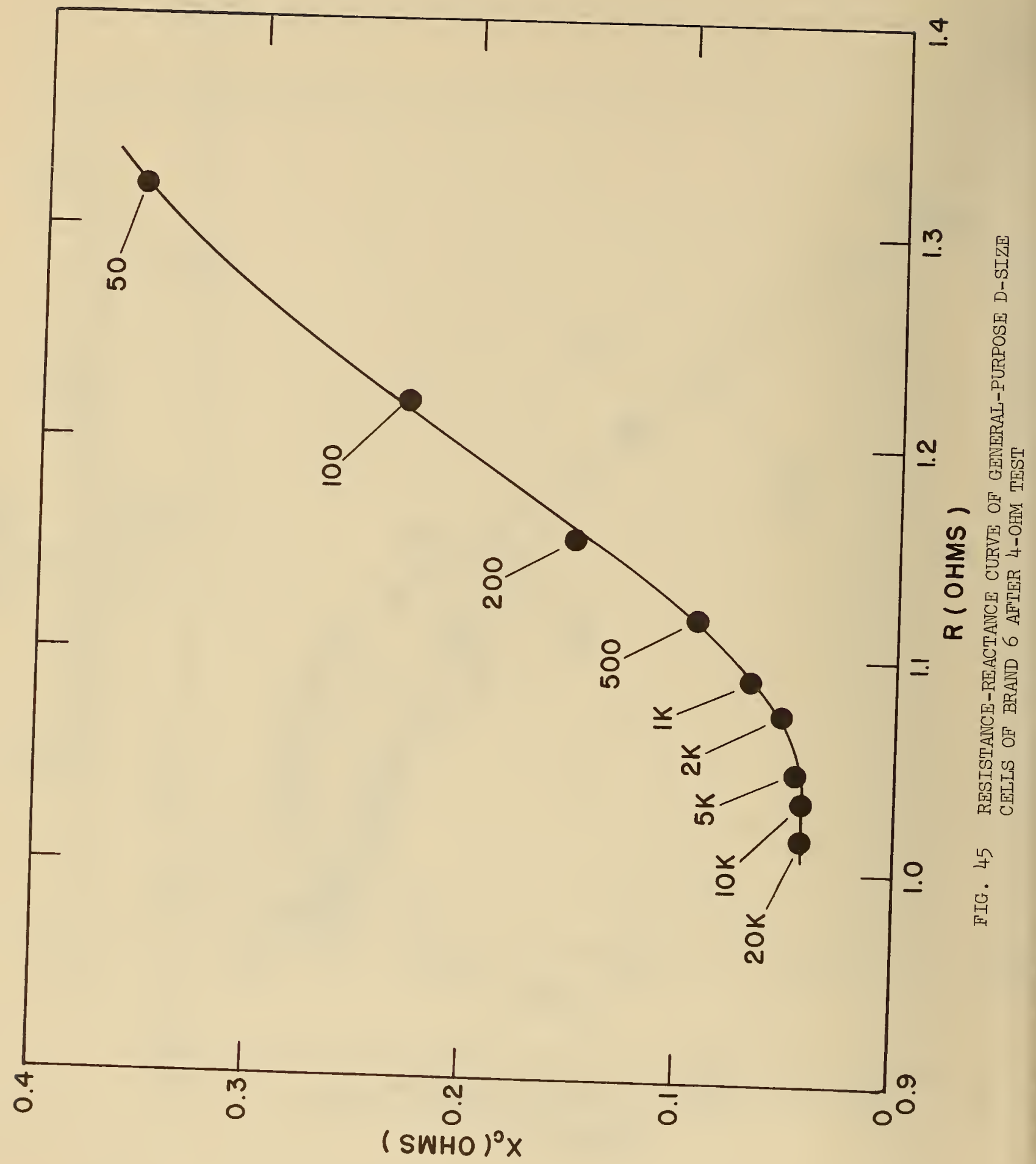




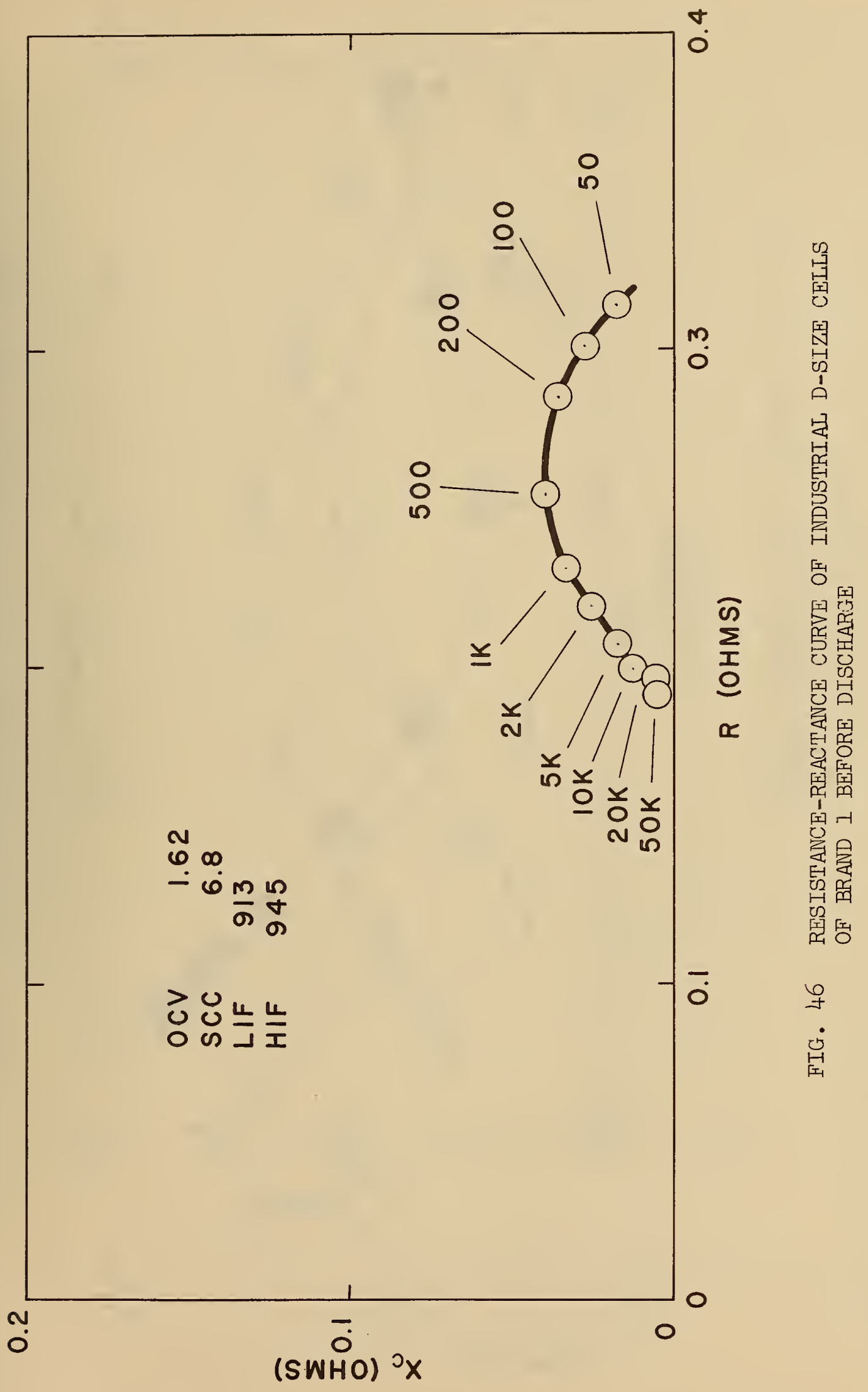




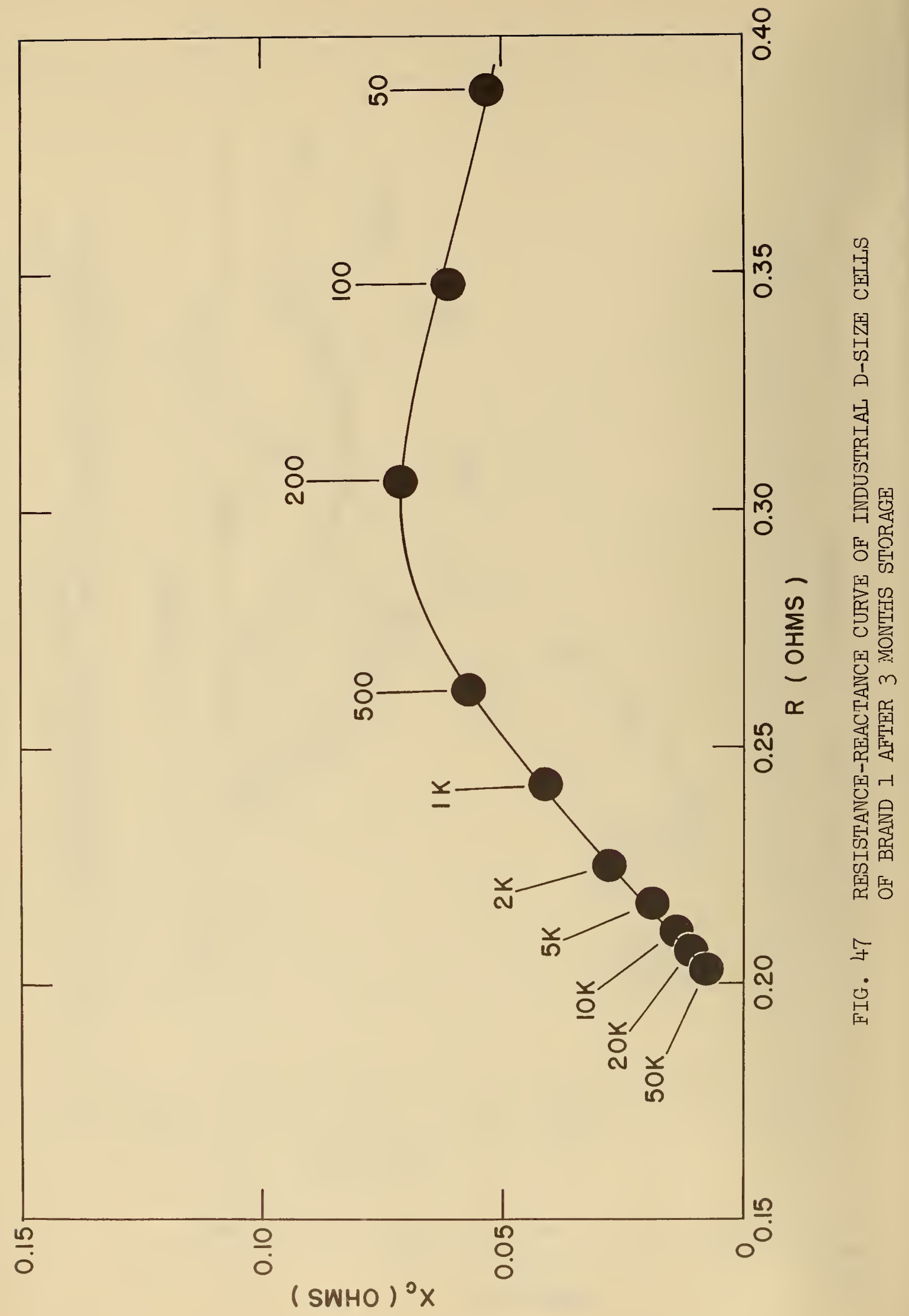




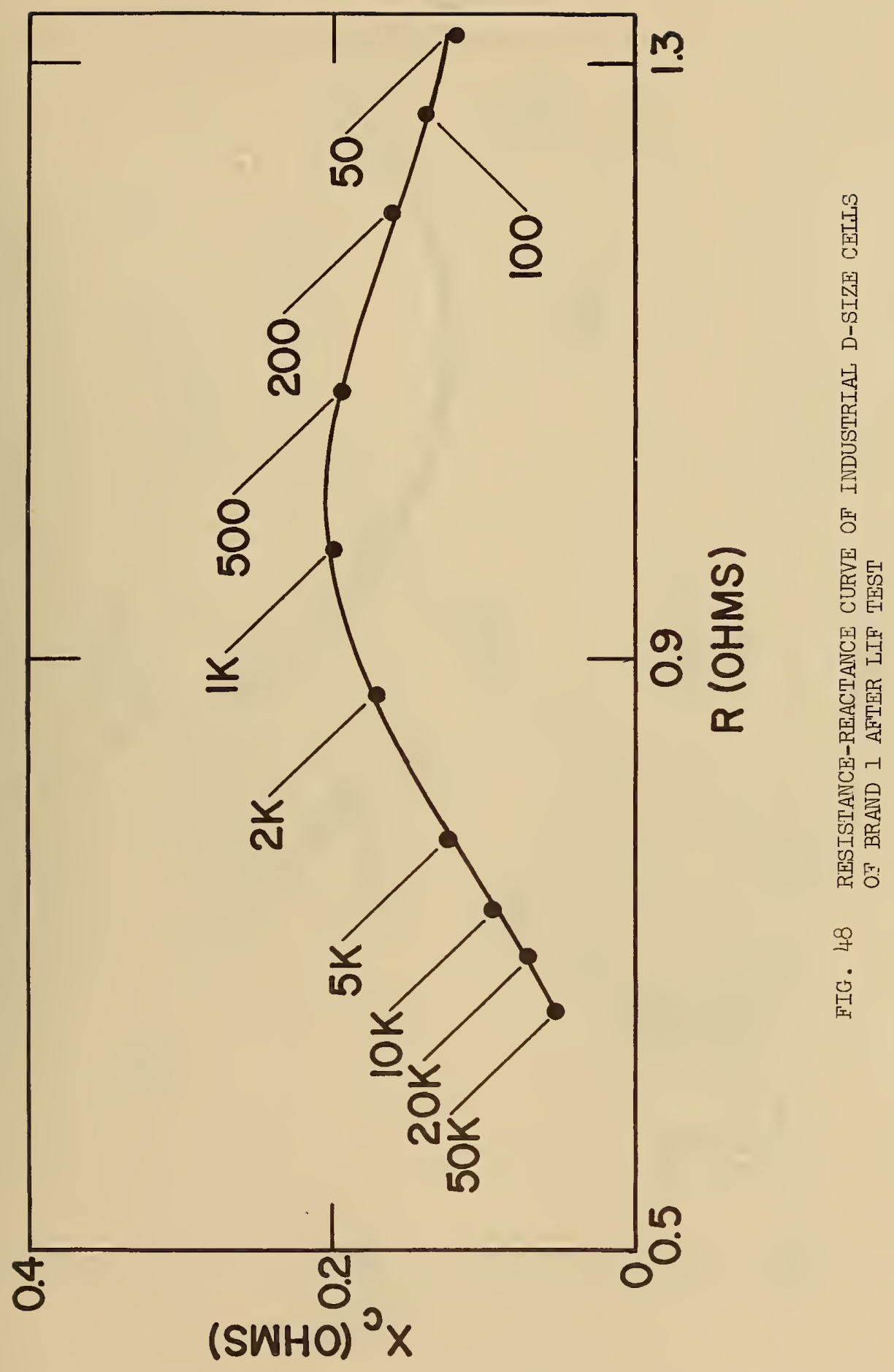




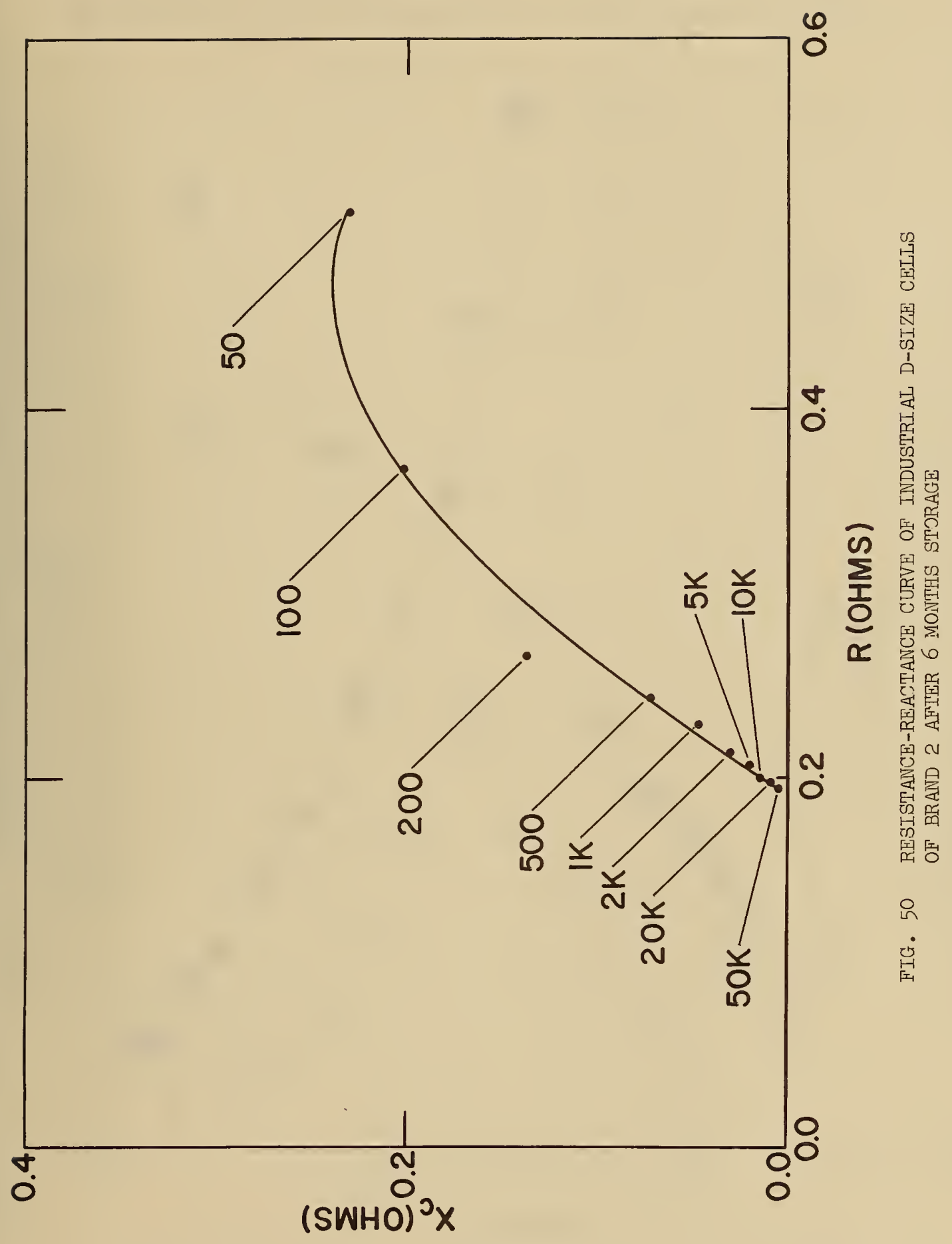




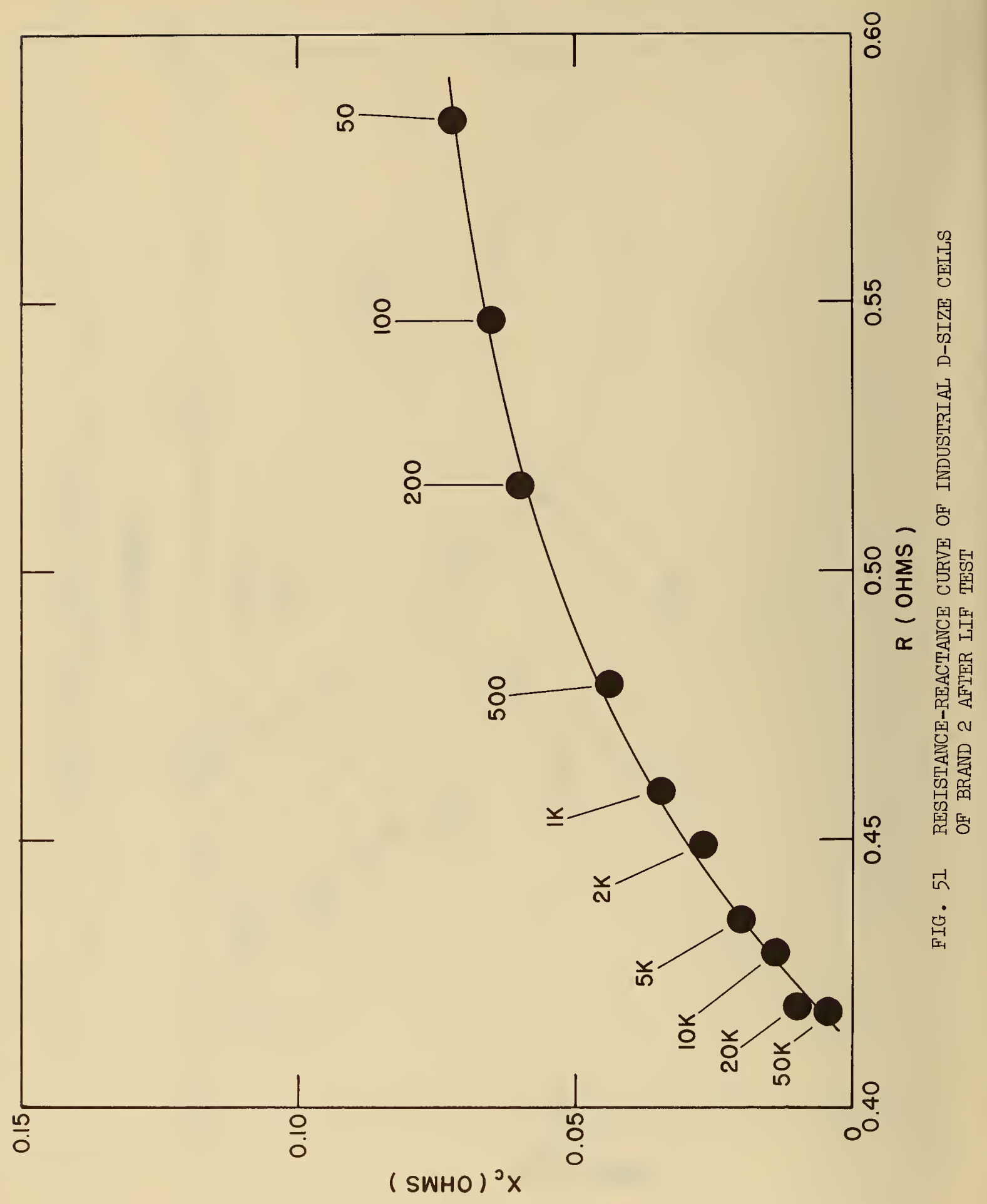



U. S. DEPARTMENT OF COMMEHCE

Luther H. Hodges, Secretary

NATIONAL BUREAU OF STANDARDS

A." V. Astin, Director

THE NATIONAL BUREAU OF STANDARDS

The scope of activities of the National Bureau of Standards at its major laboratorics in Washington, D.C., and Boulder, Colorado, is suggested in the following listing of the divisions and sections engaged in technical work. In ge neral, each section carries out specialized research, development, and engineering in the field indicated by its title. A brief description of the activities, and of the resultant publications, appears on the inside of the front cover.

WASIIINGTON, D. C.

Electricity. Resistance and Reactance. Electrochemistry. Electrical Instruments. Magnetic Measurements. Dielectrics. High Voltage. Absolute Electrical Measurements.

Metrology. Photometry and Colorimetry. Refractometry. Photographic Research. Length. Engineering Metrology. Mass and Volume.

Heat. Temperature Physics. Heat Measurements. Cryogenic Physics. Equation of State. Statistical Physics. Radiation Physics. X-ray. Radioactivity. Radiation Theory. High Energy Radiation. Radiological Equipment. Nucleonic Instrumentation. Neutron Physics.

Analytical and Inorganic Chemistry. Pure Substances. Spectrochemistry. Solution Chemistry. Standard Reference Materials. Applied Analytical Research. Crystal Chemistry.

Mechanics. Sound. Pressure and Vacuum. Fluid Mechanics. Engineering Mechanics. Rheology. Combustion Controls.

Polymers. Macromolecules: Synthesis and Structure. Polymer Chemistry. Polymer Physics. Polymer Charac terization. Polymer Evaluation and Testing. Applied Polymer Standards and Research. Dental Research.

Metallurgy. Engineering Metallurgy. Metal Reactions. Metal Physics. Electrolysis and Metal Deposition. Inorganic Solids. Engineering Ceramics. Glass. Solid State Chemistry. Crystal Growth. Physical Properties. Crystallography.

Building Research. Structural Engineering. Fire Research. Mechanical Systems. Organic Building Materials. Codes and Safety Standards. Heat Transfer. Inorganic Building Materials. Metallic Building Materials.

Applied Mathematics. Numerical Analysis. Computation. Statistical Engineering. Mathematical Physics. Operations Research.

Data Processing Systems. Components and Techniques. Computer Technology. Measurements Automation. Eigineering Applications. Systems Analysis.

Atomic Physics. Spectroscopy. Infrared Spectroscopy. Far Ultraviolet Physics. Solid State Physics. Electron Phys cs. Atomic Physics. Plasma Spectroscopy.

Instrumentation. Engineering Electronics. Electron Devices. Electronic Instrumentation. Mechanical Instruments. Basic Instrumentation.

Physical Chemistry. Thermochemistry. Surface Chemistry. Organic Chemistry. Molecular Spectroscopy. Elementary Processes. Mass Spectrometry. Photochemistry and Radiation Chemistry.

office of Weights and Measures.

BOLLDEK, COLO.

\section{CRYOGENIC ENGINEERING LABORATORY}

Cry ogenic Processes. Cryogenic Properties of Solids. Cryogenic Technical Services. Properties of Cryogenic Fluids.

\section{CENTRAL RADIO PROPAGATION LABORATORY}

Ionosphere Research and Propagation. Low Frequency and Very Low Frequency Research. Ionosphere Research. Prediction Services. Sun-Earth Relationships. Field Engineering. Radio Warning Services. Vertical Soundings Research.

Troposphere and Space Telecommunications. Data Reduction Instrumentation. Radio Noise. Tropospheric Measurements. Tropospheric Analysis. Spectrum Utilization Research. Radio-Meteorology. Lower Atmosphere Physics.

Radio Systems. Applied Electromagnetic Theory. High Frequency and Very High Frequency Research. Frequency Utilization. Modulation Research. Antenna Rescarch. Radiodetermination.

Upper Atmosphere and Space Physics. Upper Atmosphere and Plasma Physics. High Latitude Ionosphere Physics. lonosphere and Exosphere Scatter. Airglow and Aurora. Ionospheric Radio Astronomy.

\section{RADIO STANDARDS LABORATORY}

Radio Standards Physics. Frequency and Time Disseminations. Radio and Microwave Materials. Atomic Fre quency and Time-Interval Standards. Radio Plasma. Microwave Physics.

Radio Standards Engineering. High Frequency Electrical Standards. High Frequency Calibration Services. High Frequency Impedance Standards. Microwave Calibration Services. Microwave Circuit Standards. Low Frequency Calibration Services.

Joint Institute for Laboratory Astrophysics-NBS Group (Univ. of Colo.). 
